\title{
Global biogenic volatile organic compound emissions in the ORCHIDEE and MEGAN models and sensitivity to key parameters
}

\author{
Palmira Messina $^{1}$, Juliette Lathière ${ }^{1}$, Katerina Sindelarova ${ }^{2,3}$, Nicolas Vuichard ${ }^{1}$, Claire Granier ${ }^{2,4,5,6}$, \\ Josefine Ghattas $^{7}$, Anne Cozic ${ }^{1}$, and Didier A. Hauglustaine ${ }^{1}$ \\ ${ }^{1}$ Laboratoire des Sciences du Climat et de l'Environnement, LSCE-IPSL, CEA/CNRS/OVSQ, Université Paris-Saclay, \\ CEA-Orme des Merisiers, 91191 Gif-sur-Yvette, France \\ ${ }^{2}$ Laboratoire Atmosphères, Milieux, Observations Spatiales, LATMOS-IPSL, UPMC/CNRS/OVSQ, \\ UPMC 4 Place Jussieu, 75252 Paris, France \\ ${ }^{3}$ Department of Atmospheric Physics, Faculty of Mathematics and Physics, Charles University in Prague, Ke Karlovu 3, \\ 12116 Prague, Czech Republic \\ ${ }^{4}$ Laboratoire d'Aérologie, CNRS-Université de Toulouse, Toulouse, France \\ ${ }^{5}$ Cooperative Institute for Research in Environmental Sciences, University of Colorado, 216 UCB, \\ Boulder, Colorado 80309, USA \\ ${ }^{6}$ National Oceanic and Atmospheric Administration (NOAA) Earth System Research Laboratory, \\ Chemical Sciences Division, 325 Broadway R/CSD, Boulder, Colorado 80305-3337, USA \\ ${ }^{7}$ Institut Pierre Simon Laplace des sciences de l'environnement, UPMC 4 Place Jussieu, 75252 Paris, France
}

Correspondence to: Palmira Messina (palmira.messina@1sce.ipsl.fr)

Received: 17 November 2015 - Published in Atmos. Chem. Phys. Discuss.: 2 December 2015

Revised: 19 October 2016 - Accepted: 20 October 2016 - Published: 16 November 2016

\begin{abstract}
A new version of the biogenic volatile organic compounds (BVOCs) emission scheme has been developed in the global vegetation model ORCHIDEE (Organizing Carbon and Hydrology in Dynamic EcosystEm), which includes an extended list of biogenic emitted compounds, updated emission factors (EFs), a dependency on light for almost all compounds and a multi-layer radiation scheme. Over the 2000-2009 period, using this model, we estimate mean global emissions of $465 \mathrm{Tg} \mathrm{Cyr}^{-1}$ for isoprene, 107.5 $\mathrm{Tg} \mathrm{C} \mathrm{yr}^{-1}$ for monoterpenes, $38 \mathrm{Tg} \mathrm{Cyr}^{-1}$ for methanol, $25 \mathrm{Tg} \mathrm{C} \mathrm{yr}^{-1}$ for acetone and $24 \mathrm{Tg} \mathrm{C} \mathrm{yr}^{-1}$ for sesquiterpenes. The model results are compared to stateof-the-art emission budgets, showing that the ORCHIDEE emissions are within the range of published estimates. ORCHIDEE BVOC emissions are compared to the estimates of the Model of Emissions of Gases and Aerosols from Nature (MEGAN), which is largely used throughout the biogenic emissions and atmospheric chemistry community. Our results show that global emission budgets of the two models are, in general, in good agreement. ORCHIDEE emissions are $8 \%$ higher for isoprene, $8 \%$ lower for methanol,
\end{abstract}

$17 \%$ higher for acetone, $18 \%$ higher for monoterpenes and $39 \%$ higher for sesquiterpenes, compared to the MEGAN estimates. At the regional scale, the largest differences between ORCHIDEE and MEGAN are highlighted for isoprene in northern temperate regions, where ORCHIDEE emissions are higher by $21 \mathrm{TgC} \mathrm{yr}^{-1}$, and for monoterpenes, where they are higher by 4.4 and $10.2 \mathrm{TgC}^{-1}$ in northern and southern tropical regions compared to MEGAN. The geographical differences between the two models are mainly associated with different $\mathrm{EF}$ and plant functional type (PFT) distributions, while differences in the seasonal cycle are mostly driven by differences in the leaf area index (LAI). Sensitivity tests are carried out for both models to explore the response to key variables or parameters such as LAI and light-dependent fraction (LDF). The ORCHIDEE and MEGAN emissions are differently affected by LAI changes, with a response highly depending on the compound considered. Scaling the LAI by a factor of 0.5 and 1.5 changes the isoprene global emission by -21 and $+8 \%$ for ORCHIDEE and -15 and $+7 \%$ for MEGAN, and affects the global emissions of monoterpenes by -43 and $+40 \%$ for ORCHIDEE 
and -11 and $+3 \%$ for MEGAN. Performing a further sensitivity test, forcing ORCHIDEE with the MODIS LAI, confirms the high sensitivity of the ORCHIDEE emission module to LAI variation. We find that MEGAN is more sensitive to variation in the LDF parameter than ORCHIDEE. Our results highlight the importance and the need to further explore the BVOC emission estimate variability and the potential for using models to investigate the estimated uncertainties.

\section{Introduction}

The terrestrial biosphere emits large amounts of volatile organic compounds (VOCs) in particular terpenoids, such as isoprene, monoterpenes and sesquiterpenes, and oxygenated hydrocarbons such as methanol, acetone, formaldehyde, acetaldehyde, acetic acid or formic acid (Laothawornkitkul et al., 2009; Guenther et al., 2012a; Penũelas and Staudt, 2010). On the global scale, the ecosystem contribution to VOC emissions is significantly higher than the anthropogenic one, and accounts for 75-90\% of the total emission (Guenther et al., 1995; Lamarque et al., 2010). Biogenic volatile organic compounds (BVOCs) play a central role in atmospheric chemistry, influencing the oxidative capacity of the atmosphere (Arneth et al., 2011; Taraborrelli et al., 2012), leading to the production of tropospheric ozone in the presence of nitrogen oxides (Von Kuhlmann et al., 2003; Mao et al., 2013), and influencing the tropospheric carbon monoxide budget (Pfister et al., 2008). Additionally, BVOCs and their oxidation products lead to the formation and growth of more than $50 \%$ of the secondary organic aerosols (SOAs) (Kanakidou et al., 2005; Goldstein and Galbally, 2007; Van Donkelaar et al., 2007; Engelhart et al., 2008; Hallquist et al., 2009; Acosta Navarro et al., 2014; Tsigaridis et al., 2014). Under appropriate atmospheric conditions, BVOCs can contribute to a significant fraction of particles that evolve into cloud condensation nuclei (Riipinen et al., 2012), even enhancing the droplet number concentration in clouds (Topping et al., 2013).

Despite numerous measurements and the progressive understanding of the processes underlying their production, BVOC emission estimates are still highly uncertain, and vary significantly (Steiner and Goldstein, 2007; Arneth et al., 2008; Simpson et al., 2012; Sindelarova et al., 2014).

Over the last 20-25 years, two main methods have been developed to derive BVOC inventories: a top-down approach based on the inversion of satellite measurements, which allows BVOC emissions to be indirectly derived (Palmer et al., 2006; Barkley et al., 2013), and a bottom-up approach. The latter approach is the most widely used method for local, regional- or global-scale studies, and can be divided into two main categories: (i) an empirical method, based essentially on Guenther et al. (1995), where the response of leaf emissions to environmental changes is modelled using al- gorithms combined in a multiplicative way (Guenther et al., 2006, 2012a; Lathière et al., 2006, 2010; Steinbrecher et al., 2009; Oderbolz et al., 2013); hereafter we refer to it simply as the Guenther formulation; and (ii) a processed-based approach, where emissions are linked to the photosynthetic electron transport rate in chloroplasts (Niinemets, 2003a, b; Sitch et al., 2003; Keenan et al., 2009; Schurgers et al., 2009; Pacifico et al., 2011; Unger et al., 2013). The models discussed in this study belong to the first category of bottom-up models.

BVOC emission modelling at the global scale is a complex issue, especially because of the number of variables and processes influencing the emission of these compounds, generally characterized by strong temporal and geographical variations. A critical point is the lack of information available at the global scale related to the various biomes, making an accurate representation of the geographical distribution and of the seasonal variation of BVOC emissions difficult (Peñuelas and Staudt, 2010). The basal emission factor $(\mathrm{EF})$, for instance, defined as the emission at the leaf level under standardized environmental conditions of temperature and solar radiation (Guenther et al., 1995; Steinbrecher et al., 2009), shows large variability from one plant species to another. Nowadays, there is an increasing number of field campaigns that investigate, in addition to isoprene and bulk monoterpenes, many other important compounds for atmospheric chemistry, especially regarding the SOA formation, such as speciated monoterpenes and sesquiterpenes. More data and information are therefore available, allowing EF estimates for a wider range of BVOCs, despite the limitations for modelling purposes which will be discussed in Sect. 2.2.1. To calculate BVOC emissions, a single EF is usually assigned to each plant functional type (PFT), where one PFT represents a group of plants having the same phylogenetic, phenological and physical characteristics (Prentice et al., 1992). The choice of one single value for each PFT is especially difficult, as each PFT actually corresponds to several plant species, and EFs show, in general, a wide range of values among different plants (Kesselmeier and Staudt, 1999; Niinemets et al., 2011). Moreover, several measurements show that the emission factors are significantly sensitive to many processes and parameters that are difficult to isolate and linked to plant stress, such as drought periods, ozone exposure, insects, herbivores and pathogen attacks (for a review see Laothawornkitkul et al., 2009, and Niinemets et al., 2010), making it not easy to set EFs, even for a single plant. In addition, the link between EF variation and plant phenology is in general not taken into account, or is roughly described, especially in models that adopt the empirical approach.

In the early works focusing on BVOCs, isoprene was the only compound considered to be both light- and temperaturedependent, while the other compounds were considered to be only temperature-dependent. More recent papers show a growing evidence of the dependency of monoterpenes (Din- 
dorf et al., 2006; Holzke et al., 2006; Šimpraga et al., 2013), sesquiterpenes (Hansen and Seufert, 2003) and oxygenated BVOCs (Jacob et al., 2002, 2005; Harley et al., 2007; Millet et al., 2008, 2010; Hu et al., 2011; Wells et al., 2014) on radiation. As proposed in Guenther et al. (2012a), a general approach is now to consider, for each emitted compound, an emission fraction that depends on both temperature and solar light, as done for isoprene, with the remaining fraction dependent only on temperature. The Guenther et al. (2012a) approach considers only one value per emitted compound, whilst it has been shown that the LDF also depends on the plant species. For example, measurements of the diurnal cycle for monoterpenes above Amazonian rainforest (Rinne et al., 2002; Kuhn et al., 2002) suggest that emissions are dependent on both light and temperature, whilst the role of light in influencing monoterpene emissions from boreal Scot pine forest is less clear (Taipale et al., 2011). Moreover, Staudt and Seufert (1995) and Loreto et al. (1996) show that monoterpene emissions from coniferous trees are principally influenced by the temperature, while those from Holm oak are predominantly controlled by a light-dependent mechanism. Owen et al. (2002) find that, in the Mediterranean region, emissions of all compounds from Quercus sp. are lightdependent, the ocimene emitted by Pinus pinea is strongly correlated to light and an apparent weak light dependency is exhibited by monoterpene emissions from Cistus incanus. Ghirardo et al. (2010) provide the fraction of light-dependent monoterpene emission, being $58 \%$ for Scots pine, $33.5 \%$ for Norway spruce, $9.8 \%$ for European larch and 98-100\% for both Silver birch and Holm oak. Shao et al. (2001) and Steinbrecher et al. (1999) attribute a value of 20-30 and 25-37\%, respectively, for Scots pine. Nevertheless, there is no general agreement on the exact value of the temperature- and light-dependent fraction to assign for individual compound and PFT, as it also appears from the works mentioned right above.

Another crucial component in the estimation of BVOC emissions is the LAI, which can be either simulated using a vegetation model, or prescribed using values retrieved from satellite data or field measurements. Significant differences in terms of temporal and spatial distribution are found between the LAI estimated by measurements and the LAI calculated by models, with discrepancies of up to $100 \%$ at the global scale and more than $150 \%$ for specific biomes types (Garrigues et al., 2008; Pinty et al., 2011; Fang et al., 2012a, b). Consequently, the high uncertainty related to LAI affects the predicted regional and seasonal distribution of BVOC emissions.

According to our knowledge, most papers investigating BVOC emission sensitivity focus on the response of emissions to different experimental set-ups, changing, for instance, climate forcing and land use. For example, Oderbolz et al. (2013) pointed out the importance of the differences between the land-cover inventories, and of the uncertainties in the classification of land cover. Arneth et al. (2011) com- pared three vegetation models, changing the experimental set-up, such as the vegetation distribution and the climate forcings. Depending on the experiment considered, the total annual isoprene emissions were found to increase or decrease by more than $30 \%$. Ashworth et al. (2010) investigated the impact of varying the climate forcing temporal resolution of isoprene emission in the MEGAN model, finding a variation of isoprene emissions of up to $7 \%$ at the global scale and up to $55 \%$ in some locations. Keenan et al. (2009) investigate the effect of canopy structure using different canopy models, and they conclude that larger differences in the final emissions can be attributed to the use of different canopy models, rather than different emission model approaches. Nevertheless, very few studies have investigated the impact of the uncertainty of key parameters/variables, such as LAI, on emissions. One example is the work by Sindelarova et al. (2014), in which several simulations were performed with the MEGAN model to assess the sensitivity of isoprene emissions to many parameters and processes such as LAI, emission factors (EFs), $\mathrm{CO}_{2}$ concentration, soil moisture and the radiation scheme. The sensitivity simulations performed showed a variation in isoprene emissions of up to $50 \%$ at the global scale.

In the present work, our objectives are to (i) present the updated version of the emission module embedded in the dynamic global vegetation model ORCHIDEE (Organizing Carbon and Hydrology in Dynamic EcosystEm), (ii) provide present-day estimates of global BVOC emissions for several relevant compounds (isoprene, monoterpenes, sesquiterpenes, methanol, acetone, formaldehyde, acetaldehyde, acetic acid, formic acid and the main speciated monoterpenes) using the new emission scheme, (iii) compare the ORCHIDEE results to the widely used emission model MEGAN, putting the two models under the same forcing conditions, but retaining their particular characteristics (see Sect. 2.5), in particular the emission scheme, classes and distribution of PFTs and LAI processing and (iv) explore, at global and regional scales, the BVOC emission sensitivity to EFs, LAI and LDF in ORCHIDEE and MEGAN, and to understand the reasons behind these discrepancies. ORCHIDEE is designed to provide past, present and future scenarios of emissions from vegetation, studying the links between climate, the plant phenology and emissions. It is therefore essential that the internal variability, weaknesses and inaccuracies of the emission module are extensively investigated. The proper way to assess the correctness of a model would be to evaluate it against observations, as it is done, for example, for organic aerosols by Mann et al. (2014) and Tsigaridis et al. (2014) and for tropical mountain forest carbon store by Spracklen and Righelato (2014). The evaluation of BVOC emission models against observations has already been carried out at local and regional scales (i.e. Karl et al., 2007; Kuhn et al., 2007; Lathière et al., 2010; Smolander et al., 2014), demonstrating a good performance of the Guenther formulation. Nevertheless, given the ecosystem biodi- 
versity, the huge variability of the parameters involved and the poor spatial and temporal coverage of BVOC emission observations, it is extremely difficult to infer a robust evaluation at global scale. In such a context we can rely on model inter-comparison and sensitivity tests in order to assess the limitations and uncertainties of BVOC emission estimates, to relate them to particular key parameters/variables and to investigate their origin. In Sect. 2, the ORCHIDEE model and the updates from the previous version (Lathière et al., 2006), the MEGAN model and the technical details of the simulations are described. The comparison with other published estimates, the inter-comparison between the two models and the sensitivity tests carried out are extensively described in Sect. 3. The conclusions and future directions are provided in Sects. 4 and 5.

\section{Model developments and set-up}

\subsection{ORCHIDEE model: general description}

ORCHIDEE (Organizing Carbon and Hydrology in Dynamic EcosystEm) is a dynamic global vegetation model (Krinner et al., 2005; Maignan et al., 2011) that consists of two main parts: the carbon module STOMATE (SaclayToulouse-Orsay Model for the Analysis of Terrestrial Ecosystems) and the surface vegetation atmosphere transfer scheme SECHIBA (Schématisation des échanges hydriques à l'interface biosphere-atmosphère, in English: mapping of hydrological exchange at the biosphere/atmosphere interface).

STOMATE describes processes such as photosynthesis, carbon allocation, litter decomposition, soil carbon dynamics, maintenance and growth respiration. A completely prognostic plant phenology including leaf critical age, maximum LAI (leaf area index), senescence, plant tissue allocation, and leaf photosynthetic efficiency, which varies depending on the leaf age, is also taken into account. The soil water budget and the exchanges of energy and water between the atmosphere and the biosphere are calculated in SECHIBA (Krinner et al., 2005). The Choisnel hydrological scheme is used with a $2 \mathrm{~m}$ soil column represented by two moisture layers: a superficial layer and a deep layer (Ducoudré et al., 1993). The biogenic emission scheme, of which we present a new version, is embedded in this module (Lathière et al., 2006).

In ORCHIDEE, ecosystems are represented by 13 plant functional types (PFTs, listed in Table 1). Each PFT is representative of a specific set of plant species that are grouped according to plant physiognomy (tree or grass), leaf shape (needleleaf or broadleaf), phenology (evergreen, summergreen or raingreen) and photosynthesis type for crops and grasses (C3 or $\mathrm{C} 4)$. The main biophysical and biogeochemical processes for each PFT are described in Krinner et al. (2005) and in Maignan et al. (2011). For our study, the global vegetation distribution is prescribed for all runs using appropriate forcings, as described in Sect. 2.4.

\subsection{BVOCs in ORCHIDEE: module improvements}

The BVOC module is extensively updated, considering recent findings regarding emission schemes and field measurements. The new BVOC emission scheme is a development of the module implemented in ORCHIDEE by Lathière et al. (2006), and is based on the model presented by Guenther et al. (2012a). It now provides a multi-layer canopy model, where radiation is calculated following the scheme proposed by Spitters (1986) and Spitters et al. (1986) and the one already used in ORCHIDEE for the calculation of photosynthesis. The canopy is considered to be split vertically into several LAI layers, the number of which (up to 17) depends on the LAI value. Emissions are calculated for each layer through consideration of the sunlit and shaded leaf fractions and the light extinction and light diffusion through canopy. In a second step they are vertically summed, providing a single value for each PFT and grid point.

The emission flux $F$ of a specific biogenic compound $c$, for a given PFT $i$ at a LAI layer $l$ is calculated following Eq. (1):

$F_{c, i}(l)=\mathrm{LAI}_{i}(l) \cdot \mathrm{SLW}_{i} \cdot \mathrm{EF}_{c, i} \cdot \operatorname{CTL}_{c}(l) \cdot L_{c}$,

where $\operatorname{LAI}_{i}(l)$ is the leaf area index expressed in $\mathrm{m}^{2} \mathrm{~m}^{-2}$ at a particular LAI layer and PFT, $\mathrm{SLW}_{i}$ is the specific PFT leaf weight in $\mathrm{g} \mathrm{m}^{-2}, \mathrm{EF}_{c, i}$ is the basal emissions at the leaf level for an individual compound and PFT at standard conditions of temperature $(T=303.15 \mathrm{~K})$ and photosynthetically active radiation $\left(\mathrm{PAR}=1000 \mu \mathrm{mol} \mathrm{m} \mathrm{m}^{-2} \mathrm{~s}^{-1}\right.$ ), expressed in $\mu \mathrm{gCg}^{-1} \mathrm{~h}^{-1}$. $\mathrm{CTL}_{c}$ is the emission activity factor, depending on the emitted compounds, which takes the deviation from the standard conditions related to temperature and PAR into account, and it is extensively described in the second part of the present paragraph. $L_{c}$ is the activity factor simulating the impact of leaf age on emissions, and is considered for isoprene and methanol. The total emission per grid cell is obtained by summing $F_{c, i}(l)$ over the layer $l$ and averaging the emission contribution of each individual PFT, weighted by PFT fractional land coverage. Further details on the original version of the emission module are given in Lathière et al. (2006).

Table 2 summarizes the principal modifications compared to the previous module version. In particular, we (i) added new emitted compounds, (ii) estimated the emissions using a multi-layer radiation scheme that calculates diffuse and direct components of light at different LAI levels, (iii) inserted a dependence on light for almost all compounds and (iv) updated the EFs.

Eight speciated monoterpenes ( $\alpha$-pinene, $\beta$-pinene, limonene, myrcene, sabinene, camphene 3-carene, t- $\beta$ ocimene) and bulk sesquiterpenes are now included in the updated ORCHIDEE emission module. We chose these 
Table 1. Plant functional types in ORCHIDEE and MEGAN and corresponding occupied surfaces in $10^{12} \mathrm{~m}^{2}$.

\begin{tabular}{|c|c|c|c|c|c|}
\hline \multicolumn{2}{|c|}{ PFT acronym } & \multicolumn{2}{|c|}{ PFT full name } & \multicolumn{2}{|c|}{ PFT surface } \\
\hline ORCHIDEE & MEGAN & ORCHIDEE & MEGAN & ORCHIDEE & MEGAN \\
\hline \multicolumn{2}{|c|}{ BaSo } & \multicolumn{2}{|r|}{ Bare soil } & 21.43 & 40.30 \\
\hline \multicolumn{2}{|c|}{ TrBrEv } & \multicolumn{2}{|c|}{ Tropical broadleaf evergreen tree } & 12.84 & 11.40 \\
\hline \multicolumn{2}{|c|}{ TrBrDe } & \multicolumn{2}{|c|}{ Tropical broadleaf deciduous tree } & 7.49 & 5.82 \\
\hline \multicolumn{2}{|c|}{ TeNeEv } & \multicolumn{2}{|c|}{ Temperate needleleaf evergreen tree } & 4.50 & 3.43 \\
\hline \multicolumn{2}{|c|}{ TeBrEv } & \multicolumn{2}{|c|}{ Temperate broadleaf evergreen tree } & 4.04 & 1.81 \\
\hline \multicolumn{2}{|c|}{ TeBrDe } & \multicolumn{2}{|c|}{ Temperate broadleaf deciduous tree } & 5.79 & 4.45 \\
\hline \multicolumn{2}{|c|}{ BoNeEv } & \multicolumn{2}{|c|}{ Boreal needleleaf evergreen tree } & 5.74 & 9.71 \\
\hline \multicolumn{2}{|c|}{ BoBrDe } & \multicolumn{2}{|c|}{ Boreal broadleaf deciduous tree } & 5.14 & 1.68 \\
\hline \multicolumn{2}{|c|}{ BoNeDe } & \multicolumn{2}{|c|}{ Boreal needleleaf deciduous tree } & 1.98 & 1.47 \\
\hline \multirow[t]{2}{*}{ C3Gr } & C3GrCold & C3 Grass & C3 Grass Cold & 37.00 & 4.20 \\
\hline & C3GrCool & & C3 Grass Cool & & 12.55 \\
\hline \multicolumn{2}{|c|}{$\mathrm{C} 4 \mathrm{Gr}$} & \multirow{3}{*}{\multicolumn{2}{|c|}{$\begin{array}{l}\text { C3 Agriculture } \\
\text { C4 Agriculture }\end{array}$}} & 14.89 & 11.025 \\
\hline C3Ag & Crop & & & 10.19 & 14.58 \\
\hline $\mathrm{C} 4 \mathrm{Ag}$ & & & & 4.88 & \\
\hline- & TeSbEv & - & Temperate shrub evergreen & - & 0.074 \\
\hline- & TeSbDe & - & Temperate shrub deciduous & - & 5.39 \\
\hline- & BoSbD & - & Boreal shrub deciduous & - & 8.02 \\
\hline
\end{tabular}

compounds because measurements have shown that they are emitted from vegetation in the greatest abundance and because of their importance in atmospheric chemistry, in particular regarding secondary organic aerosol formation.

We mentioned that the emission module has also been modified to include a light dependency for almost all compounds emitted. In the previous module version, indeed, isoprene was the only compound dependent on both light and temperature, while the others were only dependent on temperature. As detailed in Sect. 1, most recent field campaigns highlight, for a large number of plants, the dependency of monoterpenes, sesquiterpenes and oxygenated BVOC emissions on radiation as well. Adopting a detailed parameterization is not yet possible because of the lack of data at global scale. Therefore, in the new emission module we consider the approach described in Guenther et al. (2012a), even if it is rather oversimplified. BVOCs are now modelled to consider both light-dependent and light-independent emission processes, and the response to temperature and light (CTL) is calculated for individual compounds at each LAI layer $(l)$ :

$\mathrm{CTL}_{c}(l)=\left(1-\mathrm{LDF}_{c}\right) \cdot \mathrm{CTLI}_{c}+\mathrm{LDF}_{c} \cdot \mathrm{CTLD} \cdot \mathrm{CL}(l)$.

$\mathrm{LDF}_{c}$ is the light-dependent fraction of the emission, specified for each compound emitted (Table 2). To choose the LDF value for monoterpenes, we rely on Dindorf et al. (2006), Holzke et al. (2006), Guenther et al. (2012a) and Šimpraga et al. (2013). Other LDF values were based on Guenther et al. (2012a). CTLI $c$ is the temperature-dependent emission response that is not light-dependent and depends on individual compounds. CTLD and CL are the temperature and light responses for the light-dependent fraction, respectively, and are the same functions as in the previous version of the emissions module. For all details we refer to Guenther et al. (1995) and Lathière et al. (2006). CTLI is equal to

$\mathrm{CTLI}=\exp \left(\beta\left(T-T_{0}\right)\right)$,

where $\beta$ is the empirical coefficient of the exponential temperature response, and it is now defined as in Guenther et al. (2012a) (Table 2).

\subsubsection{Emission factor update}

EF determination represents one of the greatest sources of uncertainty in the quantification of BVOC emissions (Niinemets et al., 2011). Several measurement campaigns were carried out over the last decade, providing important new insights and information for re-examining the emission factors used in the emission module and correcting them accordingly. Nevertheless, the methodology to assess EFs is still under debate within the scientific community. Assigning EFs, especially on the global scale, is very tricky. In the ideal case, for each compound emitted, we should consider the EFs of all plants belonging to one particular PFT and the land cover of each plant. We could then, for each PFT and compound, make averages weighted by plant land cover, thus obtaining an average EF for each PFT and emitted compound. Unfortunately, there are not yet enough observations available to use such a methodology.

Several aspects make it difficult to find a good strategy to assign EFs. First, sources of information regarding EFs are 


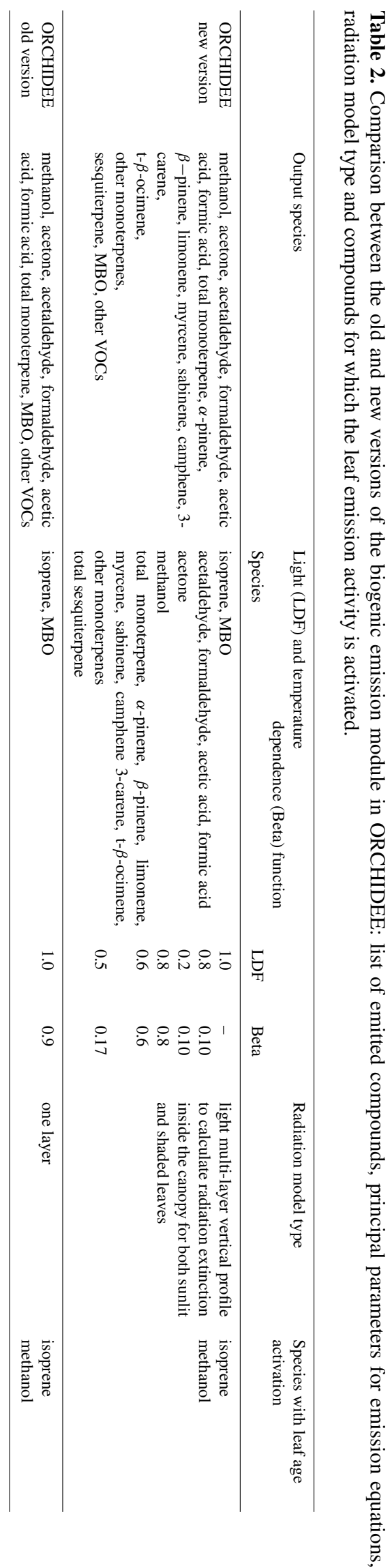

very heterogeneous such as bibliographical reviews, articles presenting punctual or fairly widespread measurement campaigns and modelling experiments, making the selection of papers to use especially tricky. When a large range of EF values is documented for one particular plant species, it is not obvious whether this range is actually representative of a natural (geographical or species-to-species) variability, and can therefore be considered as valid, or originates from technical difficulties or improvements (and, in this case, if preference should be given to more recently published papers). A further difficulty is linked to the high number of plant species that can be combined together into one PFT, in comparison to the relatively small proportion of plant species and/or measurement sites worldwide that could be investigated, despite numerous and crucial field studies. Moreover, our EF review shows that EFs are highly variable from one plant to another, even if the plants belong to the same PFT. In this context, it is difficult to assign a single EF per each PFT, which integrates this variability adequately. Lastly, the procedure itself used to determine EFs from field measurements adds another source of uncertainty. Indeed, EFs are derived by adjusting the measured flux at leaf level in standard conditions of photosynthetically active radiation (PAR) and temperature, using algorithms such as Guenther et al. (1995). However, there is no universal agreement on the parameterization of these algorithms (Tarvainen et al., 2005; Duhl et al., 2008; Kim et al., 2010; Bracho-Nunex et al., 2011; Fares et al., 2011).

All these aspects underline the challenge and uncertainty of assigning one fixed EF value for each PFT in global models (Kesselmeier and Staudt, 1999; Niinemets et al., 2010; Arneth et al., 2011), also considering that the emission estimates are very sensitive to changes in EF.

In this particular context, we try to establish a sufficiently consistent methodology, and we follow the guidelines below to update the EFs in the ORCHIDEE emission scheme. All the values and related references used to define the new EFs are provided in Tables S1-S10 (one table for each compound) of the Supplement.

a. First, we select only papers that provide EFs per leaf biomass and for standard conditions such as defined in ORCHIDEE (PAR $=1000 \mu \mathrm{mol} \mathrm{m}^{-2} \mathrm{~s}^{-1}$ and temperature $=30^{\circ} \mathrm{C}$ ). We do not consider papers where EFs were given per leaf area, per area or in different standard conditions, unless the information needed to convert the EFs accordingly was available.

b. When the most recent papers agree on a specific EF range, we discard the old references if the EF value is significantly different. In other cases all the works collected are taken into account.

c. First for each paper we gather all the values available per ORCHIDEE PFT and per emitted compound. In there are more values per paper, we calculate the av- 
erage in order to have one EF per compound, PFT and paper.

d. Then, for each compound and each PFT, we choose an $\mathrm{EF}$ that is in the range of the collected values, and is the closest to the average and median calculated. When one EF value cannot be clearly assigned, we take a value between the average or the median and the previous ORCHIDEE EF values (Lathière et al., 2006). Considering the high sensitivity of the emission module to $\mathrm{EF}$ variation, in order to avoid unreliable estimate, in the case of ambiguity, for the highly emitted compounds, in particular for isoprene, a more conservative approach is adopted, and the EF values of the previous version are kept.

e. In choosing the new EFs, in the case of very little or inconclusive information, EF variability between the different PFTs of the old version of ORCHIDEE (Lathière et al., 2006) and/or MEGAN (Guenther et al., 2012a) is taken into account.

f. For each compound we check a posteriori that the new set of EFs provides a regional distribution that is consistent with the orders of magnitude expected and given in the literature. Only for monoterpenes for tropical PFTs do we replace the first value selected $\left(2.5 \mu \mathrm{gC} \mathrm{g}^{-1} \mathrm{~h}^{-1}\right)$ with the current value $\left(2.0 \mu \mathrm{gC} \mathrm{g}^{-1} \mathrm{~h}^{-1}\right)$.

Table 3 shows the new and old EFs used in the emission module, and Table 4 shows the EF values for each speciated monoterpene as a percentage of the bulk monoterpene $\mathrm{EF}$ value. As shown in Table 3, the revision leads to the modification of almost all EFs. In some cases, the EF differences in comparison with the previous version are very significant. Regarding isoprene, boreal needleleaf deciduous PFT is now recognized as a less important emitter $\left(\mathrm{EF}=8 \mu \mathrm{gC} \mathrm{g}^{-1} \mathrm{~h}^{-1}\right.$ in the old version and $\mathrm{EF}=0.5 \mu \mathrm{gCg}^{-1} \mathrm{~h}^{-1}$ in the new one). The new EF is decided considering the $\mathrm{EF}$ proposed by Guenther et al. (2006) $\left(0.003 \mu \mathrm{gC} \mathrm{g}^{-1} \mathrm{~h}^{-1}\right)$, Guenther et al. (2012a) (0.002 $\left.\mu \mathrm{gC} \mathrm{g}^{-1} \mathrm{~h}^{-1}\right)$, Steinbrecher et al. (2009) and Karl et al. (2009) (0.44 $\left.\mu \mathrm{gC} \mathrm{g}^{-1} \mathrm{~h}^{-1}\right)$, Smiatek and Steinbrecher (2006) $\left(0.10 \mu \mathrm{gC} \mathrm{g}^{-1} \mathrm{~h}^{-1}\right)$ and Klinger et al. (2002) $\left(2.23 \mu \mathrm{gC} \mathrm{g}^{-1} \mathrm{~h}^{-1}\right)$ (more details in the Supplement). Our choice is confirmed by Ruuskanen et al. (2007), who assign a contribution of less than $3 \%$ of the VOC emission to isoprene, 2-methyl-3-buten-2-ol (hereafter referred to it simply as MBO) and 1,8-cineole, for larch, which is the major component of boreal needleleaf deciduous PFT.

Furthermore, we consider boreal broadleaved deciduous trees to be a higher emitter of isoprene than in the previous model version (now $\mathrm{EF}=18 \mu \mathrm{gCg}^{-1} \mathrm{~h}^{-1}$, while before $\mathrm{EF}=8 \mu \mathrm{gCg}^{-1} \mathrm{~h}^{-1}$ ), since the papers collected propose particularly high values, such as Guenther et al. (2012a) $\left(22.7 \mu \mathrm{gC} \mathrm{g}^{-1} \mathrm{~h}^{-1}\right)$, Guenther et al. (2006) (30.8 $\left.\mu \mathrm{gC} \mathrm{g}^{-1} \mathrm{~h}^{-1}\right)$, Stewart et al. (2003) (33.9 $\mu \mathrm{gC} \mathrm{g}^{-1} \mathrm{~h}^{-1}$ ) and Smiatek and Steinbrecher (2006) (18.8 $\left.\mu \mathrm{gCg}^{-1} \mathrm{~h}^{-1}\right)$. For monoterpenes, we assign a significantly higher EF (from 0.8 to $2.0 \mu \mathrm{gC} \mathrm{g}^{-1} \mathrm{~h}^{-1}$ ) to tropical broadleaf evergreen and deciduous PFTs. For MBO, we reduce the EF for the temperate needleleaf evergreen PFT from 20 to $1.4 \mu \mathrm{gC} \mathrm{g}^{-1} \mathrm{~h}^{-1}$ (Tarvainen et al., 2005; Hakola et al., 2006; Chang et al., 2009; Kim et al., 2010).

\subsection{MEGAN description}

The Model of Emissions of Gases and Aerosols from Nature (MEGAN) is a modelling system for the estimation of emission fluxes of biogenic organic compounds from terrestrial vegetation. The basis of the model is a simple mechanistic approach established by Guenther et al. (1991, 1993, 1995), which links emissions with the main environmental driving factors such as solar radiation and leaf temperature. Further development of the algorithm led to the inclusion of leaf ageing, soil moisture impact on the emissions and effects of the loss and production of compounds within a forest canopy (Guenther et al., 2006). The current version of the model, MEGANv2.1, also includes a full canopy module. The model calculates light and temperature conditions inside a canopy by evaluating the energy balance on five canopy levels. Additionally, emissions of each compound are considered to have light-dependent and light-independent components defined by the light-dependent fraction (LDF). For a detailed description of emission equations and parameterization we refer to Sect. 2 in Sindelarova et al. (2014) and Guenther et al. (2012a).

MEGANv2.1 is available either as a stand-alone version or embedded in the Community Land Model version 4 (CLM4) (Lawrence et al., 2011) of the Community Earth System Model (CESM) (Gent et al., 2011). When operating in the stand-alone version, the driving variables, such as meteorological input data, vegetation description and leaf area index, need to be provided by the user. When running MEGAN inside CLM4, the input data can be provided by the CESM atmospheric and land surface models online at each time step. In this work, we use the stand-alone model version of MEGANv2.1, hereafter simply referred to as MEGAN.

MEGAN estimates emissions of 19 chemical compound classes, which are then redistributed into 147 final output model species, such as isoprene, monoterpene and sesquiterpene species, methanol, carbon monoxide, alkanes, alkenes, aldehydes, ketones, acids and other oxygenated VOCs. Although the input parameters, such as vegetation description and emission potentials, can be defined by the user, MEGAN comes with a default definition of PFTs and the emission factors assigned to them. The vegetation distribution is described with fractional coverage of 16 PFT classes, consistent with those of the CLM4 model (Lawrence and Chase, 2007). The emission potential of each modelled species is calculated based on the PFT coverage and emission factor of each PFT category. For several VOC compounds, emission 
Table 3. Emission factors (EFs, $\mu \mathrm{gCg} \mathrm{g}^{-1} \mathrm{~h}^{-1}$ ) for each PFT for the main compounds emitted, in the previous (first line) and actual (second line, in bold) version of the ORCHIDEE emission module. The list of references used to set the new values is provided in the last column.

\begin{tabular}{|c|c|c|c|c|c|c|c|c|c|c|c|c|c|}
\hline & TrBrEv & TrBrDe & TeNeEv & TeBrEv & $\mathrm{TeBrDe}$ & $\mathrm{BoNeEv}$ & BoBrDe & BoNeDe & $\mathrm{C} 3 \mathrm{Gr}$ & $\mathrm{C} 4 \mathrm{Gr}$ & $\mathrm{C} 3 \mathrm{Ag}$ & $\mathrm{C} 4 \mathrm{Ag}$ & References \\
\hline \multirow[t]{2}{*}{ Isoprene } & 24.0 & 24.0 & 8.0 & 16.0 & 45.0 & 8.0 & 8.0 & 8.0 & 16.0 & 24.0 & 5.0 & 5.0 & \multirow[b]{2}{*}{$\begin{array}{l}\text { He et al. (2000), Klinger et al. (2002), Levis } \\
\text { et al. (2003), Stewart et al. (2003), Padhy and } \\
\text { Varshney (2005), Bai et al. (2006), Geron et } \\
\text { al. (2006), Guenther et al. (2006, 2012a), Smi- } \\
\text { atek and Steinbrecher (2006), Karl et al. (2007, } \\
\text { 2009), Steinbrecher et al. (2009), Tsui et } \\
\text { al. (2009), Lathière et al. (2006), Leung et } \\
\text { al. (2010), Bracho-Nunez et al. (2011) }\end{array}$} \\
\hline & 24.0 & 24.0 & 8.0 & 16.0 & 45.0 & 8.0 & 18.0 & 0.5 & 12.0 & 18.0 & 5.0 & 5.0 & \\
\hline \multirow[t]{2}{*}{ Monoterp. } & 0.800 & 0.800 & 2.400 & 1.200 & 0.800 & 2.400 & 2.400 & 2.400 & 0.800 & 1.200 & 0.200 & 0.200 & \multirow[b]{2}{*}{$\begin{array}{l}\text { He et al. (2000), Janson and De Serves (2001), } \\
\text { Stewart et al. (2003), Hayward et al. (2004), } \\
\text { Karl et al. (2004, 2007, 2009), Bai et al. (2006), } \\
\text { Geron et al. (2006), Hakola et al. (2006), } \\
\text { Lathière et al. (2006), Smiatek and Stein- } \\
\text { brecher (2006), Helmig et al. (2007), Ortega et } \\
\text { al. (2008), Steinbrecher et al. (2009), Kim et } \\
\text { al. (2010), Bracho-Nunez et al. (2011), Fares et } \\
\text { al. (2011), Guenther et al. (2012a) }\end{array}$} \\
\hline & 2.000 & 2.000 & 1.800 & 1.400 & 1.600 & 1.800 & 1.400 & 1.800 & 0.800 & 0.800 & 0.220 & 0.220 & \\
\hline
\end{tabular}

\begin{tabular}{lllllllllllllll}
\hline Sesquiterp. & - & - & - & - & - & - & - & - & - & - & & - & - & -
\end{tabular}

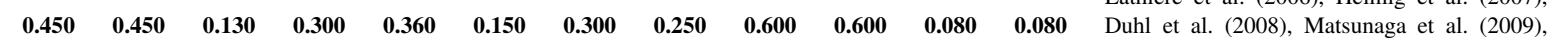
Steinbrecher et al. (2009), Karl et al. (2009), Ortega et al. (2008), Bracho-Nunez et al. (2011), Hakola et al. (2006), Kim et al. (2010), Fares et al. (2011), Guenther et al. (2012a)

\begin{tabular}{|c|c|c|c|c|c|c|c|c|c|c|c|c|c|}
\hline Methanol & $\begin{array}{l}0.600 \\
\mathbf{0 . 8 0 0}\end{array}$ & $\begin{array}{l}0.600 \\
\mathbf{0 . 8 0 0}\end{array}$ & $\begin{array}{l}1.800 \\
\mathbf{1 . 8 0 0}\end{array}$ & $\begin{array}{l}0.900 \\
\mathbf{0 . 9 0 0}\end{array}$ & $\begin{array}{l}0.600 \\
1.900\end{array}$ & $\begin{array}{l}1.800 \\
\mathbf{1 . 8 0 0}\end{array}$ & $\begin{array}{l}1.800 \\
\mathbf{1 . 8 0 0}\end{array}$ & $\begin{array}{l}1.800 \\
\mathbf{1 . 8 0 0}\end{array}$ & $\begin{array}{l}0.600 \\
\mathbf{0 . 7 0 0}\end{array}$ & $\begin{array}{l}0.900 \\
\mathbf{0 . 9 0 0}\end{array}$ & $\begin{array}{l}2.000 \\
\mathbf{2 . 0 0 0}\end{array}$ & $\begin{array}{l}2.000 \\
\mathbf{2 . 0 0 0}\end{array}$ & $\begin{array}{l}\text { Schade and Goldstein (2001), Geron et } \\
\text { al. (2002), Karl et al. (2004, 2005, 2009), } \\
\text { Hayward et al. (2004), Lathière et al. (2006), } \\
\text { Smiatek and Steinbrecher (2006), Harley } \\
\text { et al. (2007), Steinbrecher et al. (2009), } \\
\text { Bracho-Nunez et al. (2011), Fares et al. (2011), } \\
\text { Guenther et al. (2012a) }\end{array}$ \\
\hline Acetone & $\begin{array}{l}0.290 \\
\mathbf{0 . 2 5 0}\end{array}$ & $\begin{array}{l}0.290 \\
\mathbf{0 . 2 5 0}\end{array}$ & $\begin{array}{l}0.870 \\
\mathbf{0 . 3 0 0}\end{array}$ & $\begin{array}{l}0.430 \\
\mathbf{0 . 2 0 0}\end{array}$ & $\begin{array}{l}0.290 \\
\mathbf{0 . 3 0 0}\end{array}$ & $\begin{array}{l}0.870 \\
\mathbf{0 . 3 0 0}\end{array}$ & $\begin{array}{l}0.870 \\
\mathbf{0 . 2 5 0}\end{array}$ & $\begin{array}{l}0.870 \\
\mathbf{0 . 2 5 0}\end{array}$ & $\begin{array}{l}0.290 \\
\mathbf{0 . 2 0 0}\end{array}$ & $\begin{array}{l}0.430 \\
\mathbf{0 . 2 0 0}\end{array}$ & $\begin{array}{l}0.070 \\
\mathbf{0 . 0 8 0}\end{array}$ & $\begin{array}{l}0.070 \\
\mathbf{0 . 0 8 0}\end{array}$ & $\begin{array}{l}\text { Janson and De Serves (2001), Schade and Gold- } \\
\text { stein (2001), Karl et al. (2004, 2005, 2009), } \\
\text { Villanueva-Fierro et al. (2004), Lathière et } \\
\text { al. (2006), Smiatek and Steinbrecher (2006), } \\
\text { Steinbrecher et al. (2009), Bracho-Nunez et } \\
\text { al. (2011), Fares et al. (2011), Guenther et } \\
\text { al. (2012a) }\end{array}$ \\
\hline
\end{tabular}

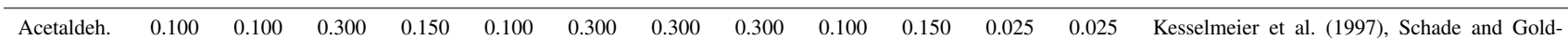

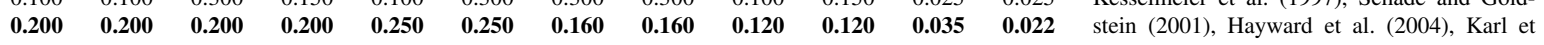
al. (2004, 2005, 2009), Villanueva-Fierro et al. (2004), Lathière et al. (2006), Smiatek and Steinbrecher (2006), Steinbrecher et al. (2009), Fares et al. (2011), Guenther et al. (2012a)

\begin{tabular}{|c|c|c|c|c|c|c|c|c|c|c|c|c|c|}
\hline Formaldeh. & $\begin{array}{l}0.070 \\
\mathbf{0 . 0 4 0}\end{array}$ & $\begin{array}{l}0.070 \\
\mathbf{0 . 0 4 0}\end{array}$ & $\begin{array}{l}0.200 \\
\mathbf{0 . 0 8 0}\end{array}$ & $\begin{array}{l}0.100 \\
\mathbf{0 . 0 4 0}\end{array}$ & $\begin{array}{l}0.070 \\
\mathbf{0 . 0 4 0}\end{array}$ & $\begin{array}{l}0.200 \\
\mathbf{0 . 0 4 0}\end{array}$ & $\begin{array}{l}0.200 \\
\mathbf{0 . 0 4 0}\end{array}$ & $\begin{array}{l}0.200 \\
\mathbf{0 . 0 4 0}\end{array}$ & $\begin{array}{l}0.070 \\
\mathbf{0 . 0 2 5}\end{array}$ & $\begin{array}{l}0.100 \\
\mathbf{0 . 0 2 5}\end{array}$ & $\begin{array}{l}0.017 \\
\mathbf{0 . 0 1 3}\end{array}$ & $\begin{array}{l}0.017 \\
\mathbf{0 . 0 1 3}\end{array}$ & $\begin{array}{l}\text { Kesselmeier et al. (1997), Janson et al. (1999), } \\
\text { Villanueva-Fierro et al. (2004), Lathière et } \\
\text { al. (2006), Smiatek and Steinbrecher (2006), } \\
\text { Chang et al. (2009), Karl et al. (2009), Stein- } \\
\text { brecher et al. (2009), Guenther et al. (2012a) }\end{array}$ \\
\hline Acetic acid & $\begin{array}{l}0.002 \\
\mathbf{0 . 0 2 5}\end{array}$ & $\begin{array}{l}0.002 \\
\mathbf{0 . 0 2 5}\end{array}$ & $\begin{array}{l}0.006 \\
\mathbf{0 . 0 2 5}\end{array}$ & $\begin{array}{l}0.003 \\
\mathbf{0 . 0 2 2}\end{array}$ & $\begin{array}{l}0.002 \\
\mathbf{0 . 0 8 0}\end{array}$ & $\begin{array}{l}0.006 \\
\mathbf{0 . 0 2 5}\end{array}$ & $\begin{array}{l}0.006 \\
\mathbf{0 . 0 2 2}\end{array}$ & $\begin{array}{l}0.006 \\
\mathbf{0 . 0 1 3}\end{array}$ & $\begin{array}{l}0.002 \\
\mathbf{0 . 0 1 2}\end{array}$ & $\begin{array}{l}0.003 \\
\mathbf{0 . 0 1 2}\end{array}$ & $\begin{array}{l}0.001 \\
\mathbf{0 . 0 0 8}\end{array}$ & $\begin{array}{l}0.001 \\
0.008\end{array}$ & $\begin{array}{l}\text { Kesselmeier et al. (1997, 1998), Staudt et } \\
\text { al. (2000), Villanueva-Fierro et al. (2004), } \\
\text { Lathière et al. (2006), Smiatek and Stein- } \\
\text { brecher (2006), Karl et al. (2009), Steinbrecher } \\
\text { et al. (2009), Guenther et al. (2012a) }\end{array}$ \\
\hline Formic acid & $\begin{array}{l}0.010 \\
\mathbf{0 . 0 1 5}\end{array}$ & $\begin{array}{l}0.010 \\
\mathbf{0 . 0 1 5}\end{array}$ & $\begin{array}{l}0.030 \\
\mathbf{0 . 0 2 0}\end{array}$ & $\begin{array}{l}0.015 \\
\mathbf{0 . 0 2 0}\end{array}$ & $\begin{array}{l}0.010 \\
\mathbf{0 . 0 2 5}\end{array}$ & $\begin{array}{l}0.030 \\
0.015\end{array}$ & $\begin{array}{l}0.030 \\
\mathbf{0 . 0 1 5}\end{array}$ & $\begin{array}{l}0.030 \\
\mathbf{0 . 0 1 5}\end{array}$ & $\begin{array}{l}0.010 \\
\mathbf{0 . 0 1 0}\end{array}$ & $\begin{array}{l}0.0150 \\
\mathbf{0 . 0 1 0}\end{array}$ & $\begin{array}{l}0.0025 \\
\mathbf{0 . 0 0 8}\end{array}$ & 0.0025 & $\begin{array}{l}\text { Kesselmeier et al. (1997, 1998), Staudt et } \\
\text { al. (2000), Villanueva-Fierro et al. (2004), } \\
\text { Lathière et al. (2006), Smiatek and Stein- } \\
\text { brecher (2006), Chang et al. (2009), Karl et } \\
\text { al. (2009), Steinbrecher et al. (2009), Guenther } \\
\text { et al. (2012a) }\end{array}$ \\
\hline MBO & $\begin{array}{l}0.000 \\
\mathbf{0 . 0 0 0 0 2}\end{array}$ & $\begin{array}{l}0.000 \\
\mathbf{0 . 0 0 0 0 2}\end{array}$ & 20.000 & $\begin{array}{l}0.000 \\
\mathbf{0 . 0 0 0 0 2}\end{array}$ & $\begin{array}{l}0.000 \\
\mathbf{0 . 0 0 0 0 2}\end{array}$ & $\begin{array}{l}0.000 \\
0.14\end{array}$ & $\begin{array}{l}0.000 \\
\mathbf{0 . 0 0 0 0 2}\end{array}$ & $\begin{array}{l}0.000 \\
\mathbf{0 . 0 0 0 0 2}\end{array}$ & $\begin{array}{l}0.000 \\
\mathbf{0 . 0 0 0 0 2}\end{array}$ & $\begin{array}{l}0.000 \\
\mathbf{0 . 0 0 0 0 2}\end{array}$ & $\begin{array}{l}0.000 \\
\mathbf{0 . 0 0 0 0 2}\end{array}$ & $\begin{array}{l}0.000 \\
\mathbf{0 . 0 0 0 0 2}\end{array}$ & $\begin{array}{l}\text { Tarvainen et al. (2005), Hakola et al. (2006), } \\
\text { Lathière et al. (2006), Chang et al. (2009), Kim } \\
\text { et al. (2010), Guenther et al. (2012a) }\end{array}$ \\
\hline
\end{tabular}


potentials can be defined in the form of input maps. Emission potential maps with global coverage and high spatial resolution for isoprene, main monoterpene species and MBO are provided together with the MEGAN code.

MEGAN is widely applied for the estimation of biogenic VOC emissions at both regional and global scales (e.g. Guenther et al., 2006, 2012a; Müller et al., 2008; Millet et al., 2010; Sindelarova et al., 2014; Situ et al., 2014; Stavrakou et al., 2014), and serves for the evaluation of the impact of BVOCs on atmospheric chemistry by coupling the model with chemistry transport models (e.g. Heald et al., 2008; Pfister et al., 2008; Emmons et al., 2010; Fu and Liao, 2012; Tilmes et al., 2015).

\subsection{Model set-up and sensitivity tests}

The objectives of the group of simulations are (i) to provide global estimates of BVOC emissions for a large variety of compounds over the 2000-2009 period, (ii) to investigate the differences and similarities between the ORCHIDEE and MEGAN results regarding the spatial, inter-annual and inter-seasonal variability of emissions and (iii) to analyse the response of BVOC emissions to the variation of some key variables and parameters such as the LAI and LDF. Table 5 summarizes the simulations performed in this study and their principal characteristics.

We carried out a total of five sets of runs:

1. two simulations for the 2000-2009 period performed by both models using each model's standard configuration, but with the same climatology (ORC_CRU and MEG_CRU);

2. one simulation for the 2000-2009 period with MEGAN using the LAI estimated by ORCHIDEE (MEG_CRULAI);

3. four simulations for the year 2006 by both models, using the ORCHIDEE LAI scaled by a factor 0.5 and 1.5 , respectively (ORC_LAI05, ORC_LAI15, MEG_LAI05 and MEG_LAI15);

4. one simulation for the year 2006 forcing ORCHIDEE with the MODIS LAI used in MEGAN standard configuration;

5. two simulations for the year 2006 performed by both models, where we output two test species, the first one totally dependent on light $(\mathrm{LDF}=1)$ and the second one totally independent of light $(\mathrm{LDF}=0)\left(\mathrm{ORC} \_\mathrm{LDF}\right.$ and MEG_LDF); the output time frequency is $1 \mathrm{~h}$ for this run.

All simulations are performed at the global scale with a spatial resolution of $0.5^{\circ} \times 0.5^{\circ}$. We use the CRU-NCEP v5.2 meteorological forcing database (http://esgf.extra.cea.fr/thredds/catalog/store/p529viov/
cruncep/V5_1901_2013/catalog.html) providing temperature, pressure, humidity, wind speed and shortwave solar radiation. This forcing is based on the 6-hourly $2.5^{\circ}$ NCEP/NCAR re-analysis (Kalnay et al., 1996) combined with the CRU TS 2.1 monthly anomalies (Mitchell and Jones, 2005). The run sets 3 and 4 are carried out for the year 2006, which is estimated as an averaged year regarding the BVOC emissions calculated by MEGAN and ORCHDEE in the 10 years of simulation. For the ORCHIDEE model a spin-up of 20 years is first performed to balance the leaf stock. The spin-up is based on a 10year loop using meteorological forcing for the year 1989, followed by a 10-year simulation from 1990 to 1999. In ORCHIDEE, the global vegetation distribution for the 13 PFTs is prescribed using the land-use history (LUHa.rc2) related to the year 2000 (Hurtt et al., 2006). The database can be found at http://esgf.extra.cea.fr/thredds/catalog/ work/p86ipsl/IGCM/BC/SRF/OL2/PFTmap_1850to2005_ AR5_LUHa.rc2/catalog.html. In MEGAN the distribution for the 16 PFTs is consistent with the Community Land Model v4 (Lawrence and Chase, 2007) and related to the year 2000. Table 1 gives the global surfaces covered by the different PFTs in ORCHIDEE and MEGAN. For the present work, MEGAN in the standard configuration is forced by the LAI retrieved by MODIS (Yuan et al., 2011; http://globalchange.bnu.edu.cn/research/lai/).

In ORCHIDEE, the activity factor $\left(L_{c}\right)$ is kept as in Lathière et al. (2006), considering four leaf age classes (new, young, mature and old leaves). For methanol, $L_{c}$ is equal to 1 for new and young leaves and equal to 0.5 for mature and old leaves, while for isoprene, $L_{c}$ is equal to 0.5 for new and old leaves and equal to 1.5 for young and mature leaves. In MEGAN, the $L_{c}$ values are taken from Table 4 in Guenther et al. (2012a); in particular, for isoprene, $L_{c}$ is equal to $0.05,0.6,1$ and 0.9 , and for methanol it is equal to 3.5, 3.0, 1.0 and 1.2 for the four leaf age classes. For both models, no soil moisture activity factor is taken into account. The annual $\mathrm{CO}_{2}$ concentration varies along the simulation from a value of $368 \mathrm{ppm}$ in 2000 to $385 \mathrm{ppm}$ in 2009. In ORCHIDEE, the variation of $\mathrm{CO}_{2}$ concentration can indirectly impact on the BVOC emission as it affects leaf growth, while in MEGAN, a $\mathrm{CO}_{2}$ inhibition factor on isoprene emission based on Heald et al. (2009) is activated. As the $\mathrm{CO}_{2}$ variation in this 10-year simulation is low, the inhibition effect is considered insignificant (Sindelarova et al., 2014) in this context. For ORCHIDEE, LDF and the $\beta$ coefficient values are given in Table 2. For MEGAN, the values of LDF and $\beta$ are those presented in Table 4 in Guenther et al. (2012a).

\subsection{Differences between ORCHIDEE and MEGAN emission algorithms}

While starting from a similar approach, the ORCHIDEE and MEGAN emission modules differ significantly in their pa- 
Table 4. Percentage of speciated monoterpene EFs with respect to the PFT bulk monoterpene EF (fourth line, in bold the Table 3) in the new version of the ORCHIDEE emission module.

\begin{tabular}{|c|c|c|c|c|c|c|c|c|c|c|c|c|c|}
\hline & TrBrEv & TrBrDe & TeNeEv & TeBrEv & TeBrDe & $\mathrm{BoNeEv}$ & BoBrDe & BoNeDe & $\mathrm{C} 3 \mathrm{Gr}$ & $\mathrm{C} 4 \mathrm{Gr}$ & $\mathrm{C} 3 \mathrm{Ag}$ & $\mathrm{C} 4 \mathrm{Ag}$ & \\
\hline$\alpha$-Pinene & 39.5 & 39.5 & 35.4 & 46.3 & 32.6 & 35.4 & 31.6 & 66.2 & 23.1 & 20.0 & 27.7 & 27.7 & $\begin{array}{l}\text { Janson et al. (1999), He et al. (2000), } \\
\text { Janson and De Serves (2001), Schade } \\
\text { and Goldstein (2001), Greenberg } \\
\text { et al. (2004), Villanueva-Fierro } \\
\text { et al. (2004), Tarvainen et al. (2005), } \\
\text { Geron et al. (2006), Ortega et al. (2008), } \\
\text { Smiatek and Steinbrecher (2006), } \\
\text { Dominguez-Taylor et al. (2007), Karl } \\
\text { et al. (2007, 2009), Steinbrecher et } \\
\text { al. (2009), Guenther et al. (2012a) }\end{array}$ \\
\hline$\beta$-Pinene & 11 & 11 & 14.6 & 12.2 & 8.7 & 14.6 & 6.3 & 15.0 & 12.3 & 8.0 & 15.4 & 15.4 & $\begin{array}{l}\text { Janson et al. (1999), He et al. (2000), } \\
\text { Janson and De Serves (2001), } \\
\text { Villanueva-Fierro et al. (2004), Tar- } \\
\text { vainen et al. (2005), Geron et al. (2006), } \\
\text { Smiatek and Steinbrecher (2006), } \\
\text { Dominguez-Taylor et al. (2007), Karl } \\
\text { et al. (2007, 2009), Ortega et al. (2008), } \\
\text { Steinbrecher et al. (2009), Guenther et } \\
\text { al. (2012a) }\end{array}$ \\
\hline
\end{tabular}

Janson and De Serves (2001)

Villanueva-Fierro et al. (2004), Bai et al. (2006), Geron et al. (2006), Smiatek and Steinbrecher (2006),

Dominguez-Taylor et al. (2007), Karl et al. (2007, 2009), Ortega et al. (2008), Steinbrecher et al. (2009), Guenther et al. (2012a)

\begin{tabular}{|c|c|c|c|c|c|c|c|c|c|c|c|c|c|}
\hline Myrcene & 7.3 & 7.3 & 5.0 & 5.4 & 2.8 & 5.0 & 1.9 & 2.5 & 6.2 & 5.7 & 4.6 & 4.6 & $\begin{array}{l}\text { Janson et al. (1999), He et al. (2000), } \\
\text { Janson and De Serves (2001), } \\
\text { Villanueva-Fierro et al. (2004), } \\
\text { Geron et al. (2006), Smiatek and Stein- } \\
\text { brecher (2006), Karl et al. (2007, 2009), } \\
\text { Ortega et al. (2008), Steinbrecher et } \\
\text { al. (2009), Guenther et al. (2012a) }\end{array}$ \\
\hline Sabinene & 7.3 & 7.3 & 5.0 & 8.3 & 0.4 & 5.0 & 26.3 & 3.0 & 6.5 & 5.0 & 6.2 & 6.2 & $\begin{array}{l}\text { He et al. (2000), Tarvainen et al. (2005), } \\
\text { Smiatek and Steinbrecher (2006), Karl } \\
\text { et al. (2007, 2009), Ortega et al. (2008), } \\
\text { Steinbrecher et al. (2009), Guenther et } \\
\text { al. (2012a) }\end{array}$ \\
\hline
\end{tabular}

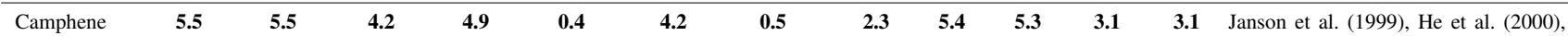
Janson and De Serves (2001), Tarvainen et al. (2005), Bai et al. (2006), Geron et al. (2006), Smiatek and Steinbrecher (2006), Karl et al. (2007, 2009), Ortega et al. (2008), Steinbrecher et al. (2009), Guenther et al. (2012a)

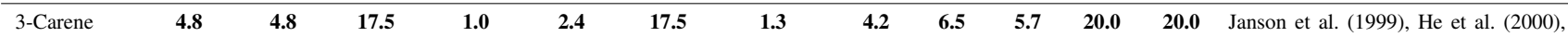
Janson and De Serves (2001), Villanueva-Fierro et al. (2004), Tarvainen et al. (2005), Bai et al. (2006), Hakola et al. (2006), Smiatek and Steinbrecher (2006), Dominguez-Taylor et al. (2007), Karl et al. (2007, 2009), Steinbrecher et al. (2009), Ortega et al. (2008), Guenther et al. (2012a)

\begin{tabular}{|c|c|c|c|c|c|c|c|c|c|c|c|c|c|}
\hline $\begin{array}{l}\mathrm{t}-\beta \text { - } \\
\text { Ocimene }\end{array}$ & 9.2 & 9.2 & 5.4 & 4.4 & 11.3 & 5.4 & 10.5 & 2.8 & 13.8 & 12.0 & 3.1 & 3.1 & $\begin{array}{l}\text { Steinbrecher et al. (2009), Karl et } \\
\text { al. (2009), Ortega et al. (2008), Guen- } \\
\text { ther et al. (2012a) }\end{array}$ \\
\hline $\begin{array}{l}\text { Other } \\
\text { monoter- } \\
\text { pene }\end{array}$ & 6.2 & 6.2 & 4.6 & 5.3 & 5.3 & 4.6 & 14.5 & 0.3 & 11.6 & 10.3 & 10.7 & 10.7 & $\begin{array}{l}\text { Janson et al. (1999), He et al. (2000), } \\
\text { Janson and De Serves (2001), Stewart } \\
\text { et al. (2003), Hayward et al. (2004), } \\
\text { Karl et al. (2004, 2007, 2009), Spirig } \\
\text { et al. (2005), Tarvainen et al. (2005), } \\
\text { Bai et al. (2006), Geron et al. (2006), } \\
\text { Hakola et al. (2006), Smiatek and Stein- } \\
\text { brecher (2006), Helmig et al. (2007), } \\
\text { Ortega et al. (2008), Steinbrecher et } \\
\text { al. (2009), Kim et al. (2010), Bracho- } \\
\text { Nunez et al. (2011), Fares et al. (2011), } \\
\text { Guenther et al. (2012a) }\end{array}$ \\
\hline
\end{tabular}


Table 5. Configuration of simulations performed by ORCHIDEE and by MEGAN.

\begin{tabular}{|c|c|c|c|c|c|c|c|c|}
\hline $\begin{array}{l}\text { Simulation } \\
\text { name }\end{array}$ & Model & $\begin{array}{l}\text { Climate } \\
\text { forcing }\end{array}$ & EFs & LDF & LAI & $T$ & Period & $\begin{array}{l}\text { Output } \\
\text { frequency }\end{array}$ \\
\hline ORC_CRU & ORCHIDEE & CRU & Standard version & Standard version & ORCHIDEE LAI & $T$ air & $2000-2009$ & 1 month \\
\hline MEG_CRU & MEGAN & CRU & Standard version & Standard version & MODIS LAI & $T$ leaf & $2000-2009$ & 1 month \\
\hline MEG_CRULAI & MEGAN & CRU & Standard version & Standard version & ORCHIDEE LAI & $T$ leaf & $2000-2009$ & 1 month \\
\hline ORC_LAI05 & ORCHIDEE & CRU & Standard version & Standard version & ORCHIDEE LAI multiplied by 0.5 & $T$ air & 2006 & 1 month \\
\hline ORC_LAI15 & ORCHIDEE & CRU & Standard version & Standard version & ORCHIDEE LAI multiplied by 1.5 & $T$ air & 2006 & 1 month \\
\hline MEG_LAI05 & MEGAN & CRU & Standard version & Standard version & ORCHIDEE LAI multiplied by 0.5 & $T$ leaf & 2006 & 1 month \\
\hline MEG_LAI15 & MEGAN & CRU & Standard version & Standard version & ORCHIDEE LAI multiplied by 1.5 & $T$ leaf & 2006 & 1 month \\
\hline ORC_CRUMOD & ORCHIDEE & CRU & Standard version & Standard version & MODIS LAI & $T$ air & 2006 & 1 month \\
\hline ORC_LDF & ORCHIDEE & CRU & $\mathrm{EFs}=1$ & $\mathrm{LDF}=1$ and 0 & ORCHIDEE LAI & $T$ air & 2006 & $1 \mathrm{~h}$ \\
\hline MEG_LDF & MEGAN & CRU & $\mathrm{EFs}=1$ & $\mathrm{LDF}=1$ and 0 & ORCHIDEE LAI & $T$ leaf & 2006 & $1 \mathrm{~h}$ \\
\hline
\end{tabular}

rameterization and variable description and calculation. We list the main differences below.

1. One of the principal differences in the two emission schemes is the approach on LAI. ORCHIDEE calculates the LAI at each model time step for each PFT and grid cell, taking a full plant phenology scheme and the environmental condition (temperature, radiation, precipitations, $\mathrm{CO}_{2}$, etc.) into account, while the MEGAN stand-alone version used in this study does not compute the LAI; rather, it has to be provided as an external forcing averaged over the vegetated part of the grid cell.

2. In ORCHIDEE, the formulation of CTLD and CL is the same as in Guenther et al. (1995) (see Eqs. 9 and 10), while in MEGAN it is defined by Eqs. (8), (9) and (10) in Guenther et al. (2012a). In particular in Guenther et al. (2012a) the parameters of the CTLD formulation vary according to the average solar radiation over the past 24 and $240 \mathrm{~h}$, and this dependence is different for diffuse and direct radiation. We calculate the CTLD obtained with this formulation considering different incoming solar radiations, and we observe that the CTLD for direct light is around twice that for diffuse light. In ORCHIDEE the CTLD parameters are fixed, and are the same for diffuse and direct radiation.

3. The radiation scheme in ORCHIDEE and MEGAN is based on the same approach (Spitters, 1986; Spitters et al., 1986), but the parameterization and formulation used are different. For example, the number of vertical layers and their distribution over the LAI significantly differ between the two models: up to 17 in ORCHIDEE and up to 5 in MEGAN. MEGAN also takes the infrared radiation into account in emission calculation.

4. The PFT classes and their distribution are not the same in the two models (Table 1), and they are not interchangeable without significantly modifying the models.

5. In ORCHIDEE, emissions are calculated for each PFT using the associated EF and LAI. Next, they are averaged over the grid cell, considering the PFT land-cover surface, as described in Sect. 2.2. In MEGAN, vegetated emission potential (EP) is calculated over the grid cell and multiplied by the average LAI over the vegetated part of the grid cell. In MEGAN, vegetated potential emission maps are provided for isoprene, $\alpha$-pinene, $\beta$ pinene, 3 -Carene, limonene, myrcene, $\mathrm{t}-\beta$-ocimene and sabinene, while for the other compounds EPs are calculated starting from the EFs per PFT and the PFT landcover distribution. This is a significantly different approach. However, for ORCHIDEE, we find that global emissions calculated using the EP and LAI per grid cell (the MEGAN approach) are only 5-12\% lower in comparison with the emissions calculated in the standard way. Isoprene presents the lowest differences, and monoterpenes present the highest differences.

6. In the ORCHIDEE model, the dependence of the light-independent emission on LAI is linear, as shown in Eqs. (1) and (2) of the present work, whereas in MEGAN, the dependence on LAI is given by the $\gamma_{\text {LAI }}$ factor that is equal to $(0.49 \times \mathrm{LAI}) /\left(1+0.2 \times \mathrm{LAI}^{2}\right)^{0.5}$ (Guenther et al., 2006). The implications of this difference are detailed in Sect. 3.4.2.

7. In MEGAN, leaf age classes are derived from consideration of the variation between the LAI value of the current and preceding month, following a highly parameterized scheme. In ORCHIDEE, leaf age classes are calculated online considering the plant leaf growth and leaf turnover at each model time step (30 min).

8. In ORCHIDEE, hydrological processes are explicitly calculated, as briefly described in Sect. 2.1.

9. In ORCHIDEE, the air temperature is used to compute emissions, while in MEGAN the leaf temperature is considered. 


\section{Results}

\subsection{Global budgets}

As already discussed at the end of the Introduction, the validation of BVOC emissions at the global scale is a complex issue because of the poor data coverage in many regions and the general lack of year-round measurements. Satellite observations provide very useful information, especially regarding the order of magnitude and the seasonal and regional variability of emissions, but the most abundant VOC species are not directly measured (such as isoprene and monoterpenes). Satellite measurements are also subject to large uncertainties arising from difficulties in the retrieval of the atmospheric concentration of short-lived compounds from space or in separation of the different sources (for instance, terrestrial biogenic, anthropogenic, oceanic) and the various compounds themselves. Global emission estimates are generally performed using models, or from the application of inverse modelling techniques that combine the measurements (from satellite, ground or aircraft measurements) and models, providing emissions for compounds such as methanol (Jacob et al., 2005; Millet et al., 2008; Stavrakou et al., 2009; Hu et al., 2011; Wells et al., 2012, 2014) and acetaldehyde (Jacob et al., 2002; Millet et al., 2010). Isoprene emissions have also been inferred from satellite formaldehyde concentration (Shim et al., 2005; Palmer et al., 2006; Stavrakou et al., 2011; Barkley et al., 2013; Bauwens et al., 2013; Stavrakou et al., 2014).

At the global scale, the main way to evaluate the results obtained in the present study is to compare them with the most recent emission budgets derived either from other model runs or from the inversion of satellite data. We have compared emissions from a large number of estimates published so far, over the 1980-2010 period, with the global emission budgets obtained from ORC_CRU and MEG_CRU simulations, the results of which are summarized in Fig. 1. The emissions, calculated by the earlier version of the emission module (black squares, Fig. 1) (Lathière et al., 2006), are particularly high, as already pointed out by Sindelarova et al. (2014). Methanol (106.1 $\mathrm{Tg} \mathrm{C} \mathrm{yr}^{-1}$ ) and acetaldehyde $\left(42.2 \mathrm{Tg} \mathrm{C} \mathrm{yr}^{-1}\right)$ emissions are twice as large, and formaldehyde emissions $\left(10.0 \mathrm{Tg} \mathrm{Cyr}^{-1}\right)$ are up to 5 times greater than the other estimates. The results of the new module version (ORC_CRU, green stars) are more in the range of other published estimates. Although the MEG_CRU simulation was carried out using the same MEGAN version as in Guenther et al. (2012a) (blue hexagons, Fig. 1), there is a noticeable difference between the two emission budgets (especially for isoprene, monoterpenes and acetaldehyde), even when considering results for the same year (e.g. 2000). Using reanalysis provided by Qian et al. (2006) as climate forcings for the year 2000, Guenther et al. (2012a) report BVOC

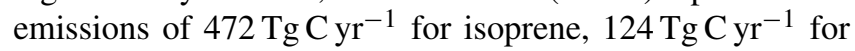
monoterpenes (considering the speciated monoterpenes accounted in this work) and $11.5 \mathrm{Tg} \mathrm{Cyr}^{-1}$ for acetaldehyde.

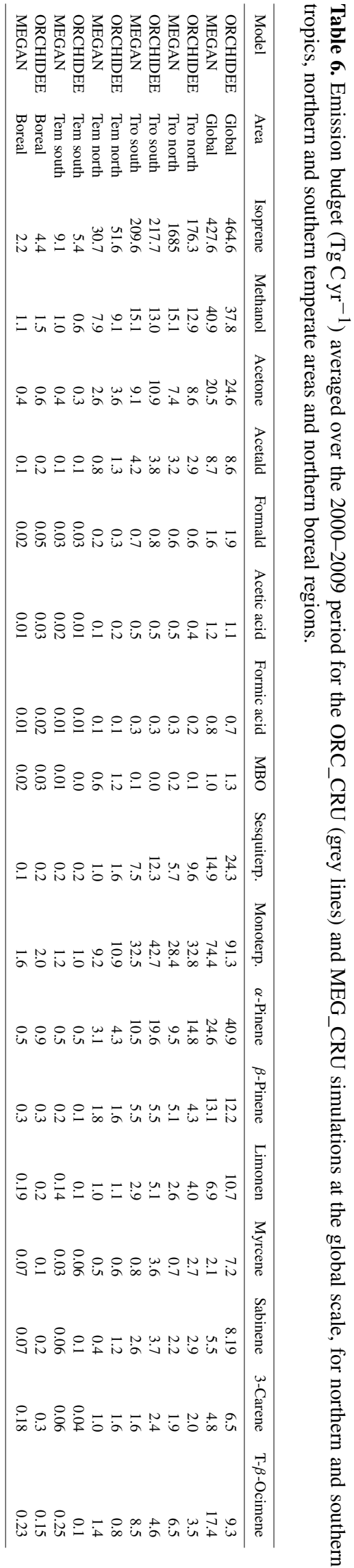

www.atmos-chem-phys.net/16/14169/2016/ 


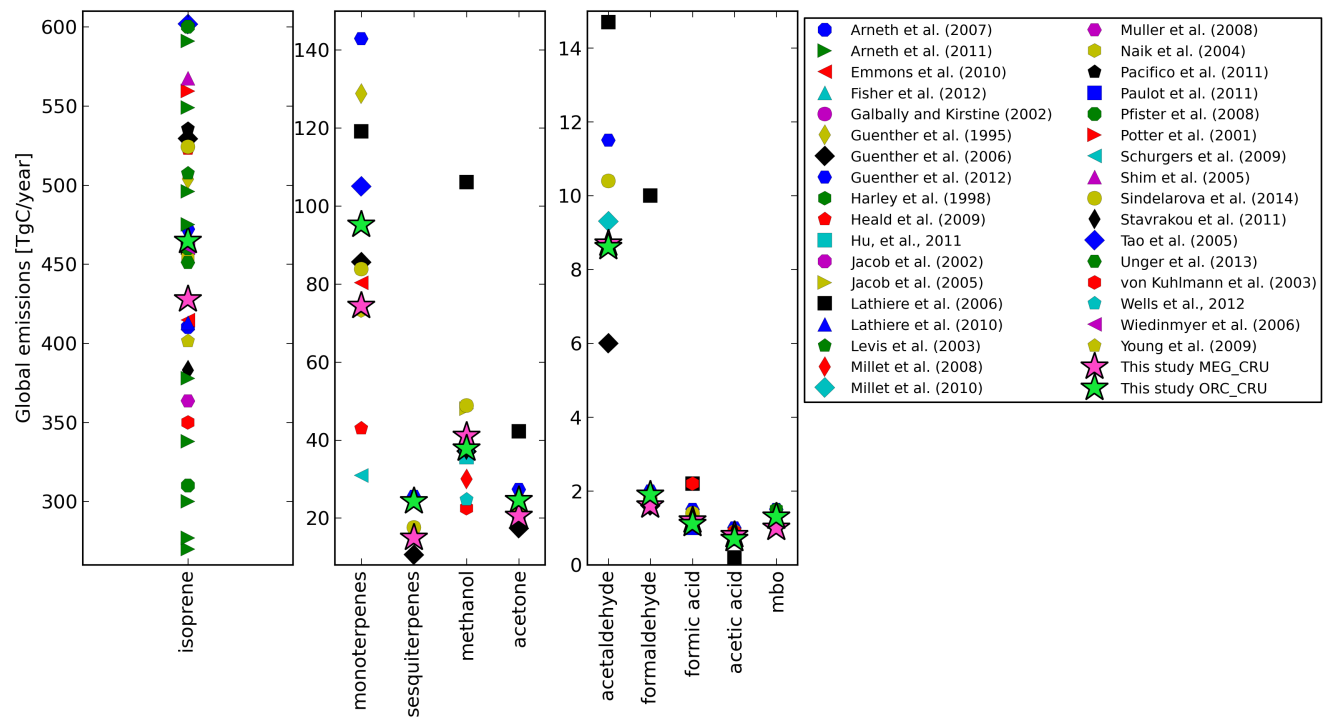

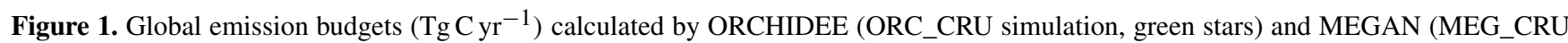
simulation, pink stars), compared with published estimates for the main BVOCs presented in this work. Note that the vertical axes have different scales in the three plots.

Our MEG_CRU simulation estimates for 2000 are 410, 72 and $8.3 \mathrm{TgC}^{-1}$ for isoprene, monoterpenes and acetaldehyde, respectively. As was already pointed out by Arneth et al. (2011), our results confirm that the differences between existing meteorological forcings can lead to substantial differences in the emission estimates (green triangles, first plot of Fig. 1).

Table 6 shows the annual emissions calculated by ORCHIDEE and MEGAN (ORC_CRU and MEG_CRU simulations) at the global scale and for the northern (lat: $0-30^{\circ} \mathrm{N}$ ) and southern (lat: $30^{\circ} \mathrm{S}-0^{\circ}$ ) tropics, the northern (lat: 30 $60^{\circ} \mathrm{N}$ ) and southern (lat: $30-60^{\circ} \mathrm{S}$ ) temperate latitudes and the northern boreal (lat: $60-90^{\circ} \mathrm{N}$ ) regions, averaged over the 2000-2009 period. At the global scale, the two models are in a good agreement. Isoprene is the main compound emitted with a global amount of $465 \mathrm{Tg} \mathrm{C} \mathrm{yr}^{-1}$ for ORCHIDEE, accounting for $61 \%$ of total BVOC emissions (estimated to $757 \mathrm{Tg} \mathrm{C} \mathrm{yr}^{-1}$ ), and $428 \mathrm{Tg} \mathrm{C} \mathrm{yr}^{-1}$ for MEGAN, accounting

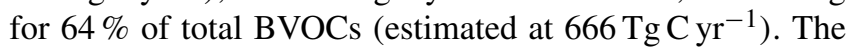
following most abundant compounds are monoterpenes, accounting for $12 \%$ of the total for ORCHIDEE and $11 \%$ for MEGAN, and methanol, accounting for $5 \%$ of the total BVOC emissions for ORCHIDEE and $6 \%$ for MEGAN. Acetone, sesquiterpenes and acetaldehyde each represent 1 to $4 \%$ of the total BVOCs for both models, while other compounds contribute to less than $0.5 \%$.

Compared to ORCHIDEE, MEGAN global emissions are $8 \%$ lower for isoprene, $8 \%$ higher for methanol, $17 \%$ lower for acetone, $18 \%$ lower for monoterpenes, $39 \%$ lower for sesquiterpenes and $25 \%$ for MBO. Regarding speciated monoterpenes, major differences arise from $\alpha$-pinene (around $40 \%$ ), while the relative difference between ORCHIDEE and MEGAN is between -8 and $+16 \%$ for other compounds. The highest contribution to total emissions is attributed to the tropical regions ranging between $34 \%$ and $50 \%$ for the southern tropics and between 31.5 and $39.5 \%$ for the northern tropics, depending on the compound (except MBO). Both models calculate the contribution of northern temperate regions to the total emission ranging from 6 to $24 \%$ and a contribution of less than $5 \%$ for southern temperate regions and northern boreal regions. For MBO, field campaigns only measured significant emissions for a few plant types such as Ponderosa and Scots pine (Kim et al., 2010; Tarvainen et al., 2005; Harley et al., 1998). The EF values in the ORCHIDEE and MEGAN models are consequently only significant for the PFTs representing these plants (TeNeEv and $\mathrm{BoNeEv}$ ), leading to notable emissions in the temperate northern latitudes, and contributing $88 \%$ for ORCHIDEE and $63 \%$ for MEGAN of the global MBO emissions.

At the regional scale, the largest differences between ORCHIDEE and MEGAN in terms of absolute values appear in the northern temperate regions for isoprene, where emissions are $21 \mathrm{Tg} \mathrm{Cyr}^{-1}$ higher in ORCHIDEE. Indeed, the marked seasonal cycle of emissions for northern temperate latitudes implies that the largest differences between ORCHIDEE and MEGAN occur in summer. The differences between the two models are, in this case, directly linked to discrepancies in the EFs and in the occupying surface of the PFTs at these latitudes (see Fig. 3, plots in the last row). In particular, in northern temperate regions the highest discrepancies are mainly due to the different PFT surface coverage for grass and crop and the higher EFs values 

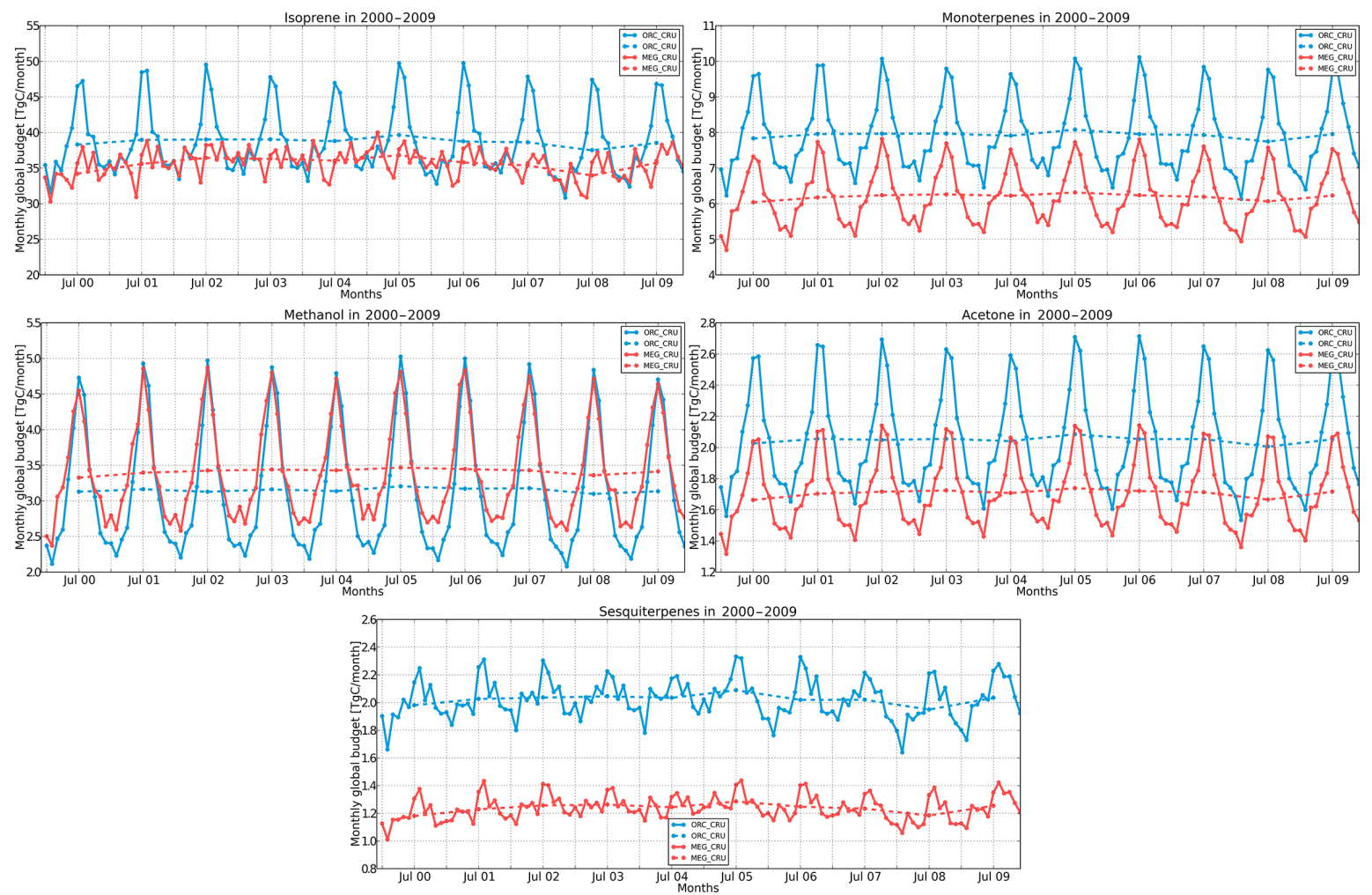

Figure 2. Monthly global (solid lines) and yearly averaged (dashed lines) emission budgets in Tg C month ${ }^{-1}$ for ORC_CRU and MEG_CRU simulations for isoprene, monoterpenes, methanol, acetone and sesquiterpenes.

in ORCHIDEE in comparison to MEGAN. Actually, in ORCHIDEE C3Gr covers the $42 \%$ of vegetated surface with an $\mathrm{EF}=12 \mu \mathrm{gCg}^{-1} \mathrm{~h}^{-1}$ and $\mathrm{C} 3 \mathrm{Ag}$ covers the $18 \%$ with an $\mathrm{EF}=5 \mu \mathrm{gCg}^{-1} \mathrm{~h}^{-1}$, while in MEGAN the $\mathrm{C} 3 \mathrm{GrCool}$ occupies the $20 \%$ with an $\mathrm{EF}=2 \mu \mathrm{gCg}^{-1} \mathrm{~h}^{-1}, \mathrm{C} 3 \mathrm{GrCold}$ the $6 \%$ with an $\mathrm{EF}=4 \mu \mathrm{gCg}^{-1} \mathrm{~h}^{-1}, \mathrm{C} 3 \mathrm{GrCool}$ the $20 \%$ with an $\mathrm{EF}=2 \mu \mathrm{gC} \mathrm{g}^{-1} \mathrm{~h}^{-1}$ and Crop the $23.2 \%$ with an $\mathrm{EF}=0.12 \mu \mathrm{gC} \mathrm{g}^{-1} \mathrm{~h}^{-1}$. This example raises an important issue. Considering the $\mathrm{EF}$ assigned to $\mathrm{C} 3 \mathrm{Gr}$, we lowered its value with respect to the previous version, from 16 to $12 \mu \mathrm{gC} \mathrm{g}{ }^{-1} \mathrm{~h}^{-1}$. These is a compromise value, chosen so that we do not excessively bias the emissions in other areas. $\mathrm{C} 3 \mathrm{Gr}$ is, indeed, strongly present in other regions: $13 \%$ of northern tropical areas, $22 \%$ of southern tropical areas and $32 \%$ of the total vegetation surface. A more detailed description of the different crop and grass (in other words with a larger number of PFTs) could lead to more accurate results. The same consideration could be done for almost all the other PFTs.

This illustrates the strong impact of different choices in EF allocation, not only regarding global estimates, but also for geographical variation in emissions. For the other species the largest differences occur in tropical regions. For example, the emission differences between ORCHIDEE and MEGAN in the northern and southern tropics are -2.2 and
$-2.1 \mathrm{TgC}^{-1}$ for methanol, 4.3 and $10.2 \mathrm{Tg} \mathrm{Cyr}^{-1}$ for monoterpenes and 3.9 and $4.9 \mathrm{Tg} \mathrm{C} \mathrm{yr}^{-1}$ for sesquiterpenes.

\subsection{Inter-annual and inter-seasonal emission variations}

Figure 2 shows the annual and monthly global emission budgets of ORC_CRU and MEG_CRU. The models have very similar annual trends and monthly variations for almost all compounds, illustrating that climate variables, in particular temperature and solar radiation, are the major driving factors at the global scale for inter-annual and inter-monthly variability.

Nevertheless, large differences appear for isoprene. The emissions in ORC_CRU present a clear seasonal cycle, with an emission maximum in July and August that is not simulated in MEG_CRU results. Indeed, the major differences can be identified in July and August, when global emissions in MEG_CRU are, on average, lower by 11.5 and 9.0 Tg C month ${ }^{-1}$ compared with ORC_CRU. The monthly zonal average for tropical, temperate and northern boreal latitudes regions are shown in Fig. 3. We observe, as mentioned in Sect. 3.1, that the ORCHIDEE emissions are significantly higher in northern temperate regions compared with MEGAN, with a marked seasonal cycle and the largest differences between the two models occurring in summer. In July (August) in particular, calculated isoprene emissions 

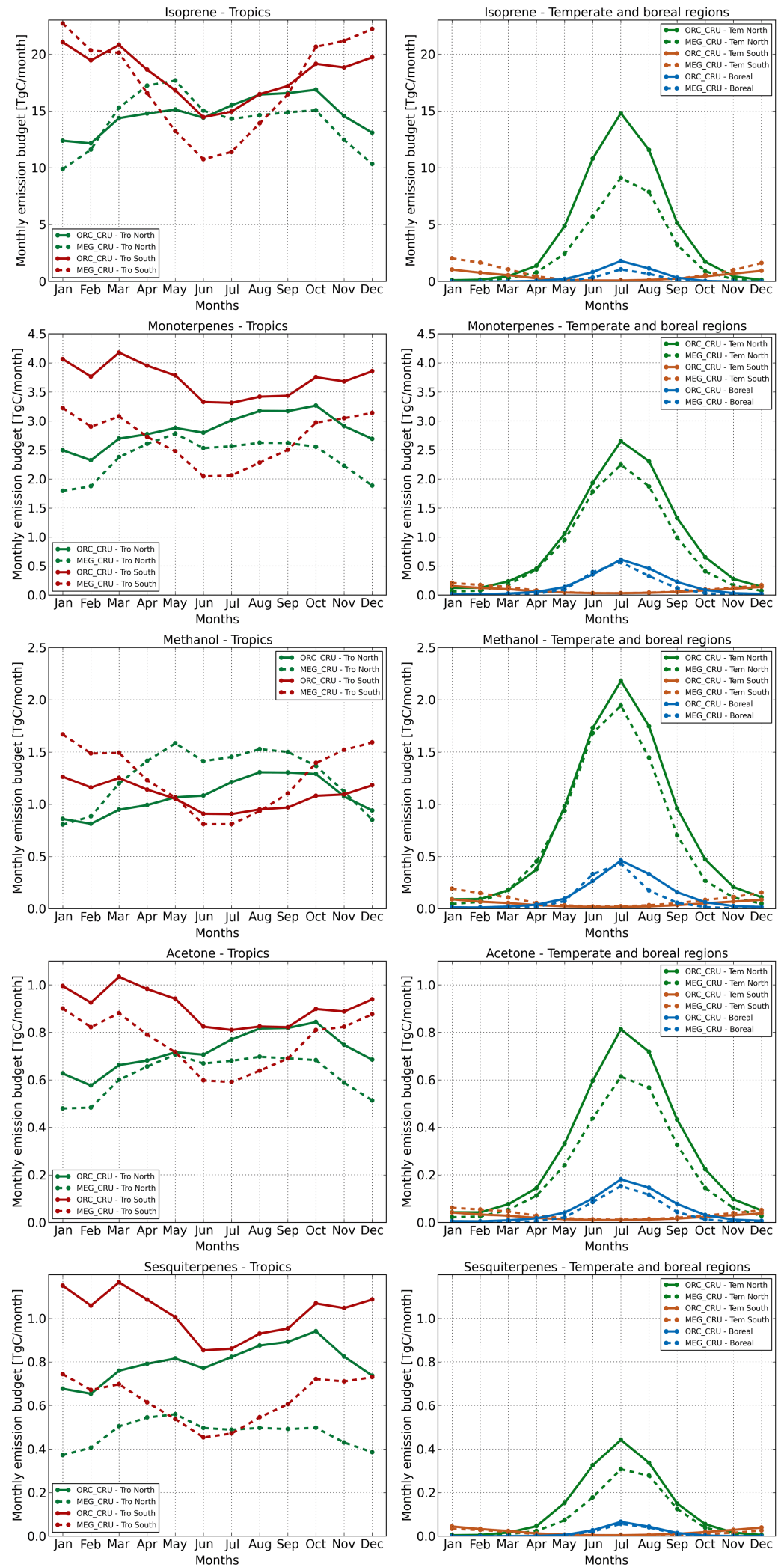

Figure 3. Zonal mean for northern and southern tropics (left column), northern and southern temperate and northern boreal latitudes (right column) of the monthly emission budget (Tg C month ${ }^{-1}$ ) averaged over the simulation period (2000-2009) in ORC_CRU and MEG_CRU runs for isoprene, monoterpenes, methanol, acetone and sesquiterpenes, respectively. 
in ORC_CRU are about $4 \mathrm{Tg} \mathrm{C}$ month $^{-1}$ (5.5 $\mathrm{Tg} \mathrm{C}$ month $^{-1}$ ) higher than in MEG_CRU. In July (August), a further important contribution to the global emission peak is attributed to the northern and southern tropics, where ORCHIDEE isoprene emissions are higher, in total, by about $4 \mathrm{Tg} \mathrm{C}$ month $^{-1}$ (5 Tg C month ${ }^{-1}$ ) in comparison to MEGAN in July (August), (Fig. 3, first plot, left column).

MEGAN isoprene emissions are indeed dominant from the tropical regions, leading to an overall stable global emission budget throughout the year (Fig. 2). The northern and southern tropics have an opposite seasonal cycle, with isoprene emissions coming mostly from the northern tropics between March and October and from the southern tropics for the rest of the year (Fig. 3). The overall stable global emission budget is generally characteristic of the compounds for which tropical regions are strong emitters all year round, such as sesquiterpenes (Table 3 and Fig. 3). On the other hand, the global BVOC emissions for which temperate regions are strong emitters will have a more marked seasonal cycle (Fig. 2), such as for methanol and isoprene in ORCHIDEE.

Indeed, the two models exhibit a very different interseasonal variation in terms of isoprene global emissions. Sindelarova et al. (2014) compared the monthly isoprene emissions time series from different data sets, showing, for some of them, an inter-seasonal variation similar to ORCHIDEE, and, for others, no seasonal cycle. Based on our current knowledge, we cannot establish which is the best representation because of the lack of long-term observations at the global scale. However, we can extensively investigate why the differences between the two models occur, by performing sensitivity simulations and looking at the various processes modelled. This is the main purpose of the next section.

Additionally, Fig. 3 shows that in northern and southern temperate and northern boreal regions, the seasonal cycle is very similar between the two models, even if ORCHIDEE calculates higher emissions than MEGAN, especially for isoprene.

\subsection{Emission geographical distribution}

The spatial patterns of BVOC emissions in winter and summer for ORC_CRU and MEG_CRU simulations are presented in Figs. 5-9 for isoprene, monoterpenes, methanol, acetone and sesquiterpenes. To better assess the impact of EFs on emissions, we show the resulting emission potential for each grid cell, summing the EFs, each weighted by the cell area occupied by each PFT. In MEGAN, emission potentials are already provided per grid cell for isoprene, monoterpenes and MBO (see Sect. 2.3). Emission potentials per grid cell can be interpreted as the average EFs associated with the ecosystem present in the grid cell.

For a particular compound, the formula to convert the ORCHIDEE EF $\left(\mu \mathrm{gCg}^{-1} \mathrm{~h}^{-1}\right)$ in the potential emission $\left(\mu \mathrm{g} \mathrm{m}^{-2} \mathrm{~h}^{-1}\right)$ consistent to those provided by MEGAN are, for emission not depending on light $(\mathrm{LDF}=0)$,

$\mathrm{EP}=\sum_{i} \mathrm{EF}_{i} \cdot M / M_{\text {Carbon }} \cdot \mathrm{LAI}_{\mathrm{REF}} \cdot \mathrm{SLW}_{i} \cdot A_{i}$,

and for light-dependent emissions $(\mathrm{LDF}=1)$,

$\mathrm{EP}=\sum_{i} \mathrm{EF}_{i} \cdot M / M_{\mathrm{Carbon}} \cdot \mathrm{LAI}_{\mathrm{REF}} \cdot \mathrm{SLW}_{i} \cdot A_{i} \cdot C_{\mathrm{CE}}$,

where $i$ is the index related to PFTs, $M_{\text {Carbon }}$ and $M$ are the molar mass of carbon and the compound, respectively, LAI $_{\text {REF }}$ equals $5.0 \mathrm{~m}^{2} \mathrm{~m}^{-2}$, which is the LAI in MEGAN standard conditions, SLW is the MEGAN specific leaf weight depending on PFTs, $A$ is the PFT grid fraction and $C_{\mathrm{CE}}$ is the canopy environment coefficient, a scaling factor dependent on the canopy radiation module, which equals 0.57 in this MEGAN configuration (Guenther et al., 2012a).

In general, for every compound, we observe a similar geographical distribution. High emission areas are identified in Brazil, equatorial Africa, southeastern Asia and southeastern United States for both models, with values for ORCHIDEE (MEGAN) ranging between: $5.0-12.0 \times 10^{10} \mathrm{~kg} \mathrm{C} \mathrm{m}^{-2} \mathrm{~s}^{-1}$ $\left(3.0-9.0 \times 10^{10} \mathrm{~kg} \mathrm{C} \mathrm{m}^{-2} \mathrm{~s}^{-1}\right) \quad$ for isoprene, $0.8-$ $2.0 \times 10^{10} \mathrm{~kg} \mathrm{C} \mathrm{m}^{-2} \mathrm{~s}^{-1} \quad\left(0.6-1.3 \times 10^{10} \mathrm{~kg} \mathrm{C} \mathrm{m}^{-2} \mathrm{~s}^{-1}\right)$ for monoterpenes, $\quad 0.3-1.2 \times 10^{10} \mathrm{~kg} \mathrm{C} \mathrm{m}^{-2} \mathrm{~s}^{-1}$ $\left(0.2-0.7 \times 10^{10} \mathrm{~kg} \mathrm{C} \mathrm{m}^{-2} \mathrm{~s}^{-1}\right) \quad$ for methanol, $0.2-$ $0.5 \times 10^{10} \mathrm{~kg} \mathrm{C} \mathrm{m}^{-2} \mathrm{~s}^{-1} \quad\left(0.1-0.3 \times 10^{10} \mathrm{~kg} \mathrm{C} \mathrm{m}^{-2} \mathrm{~s}^{-1}\right)$ for acetone and $0.4-0.6 \times 10^{10} \mathrm{~kg} \mathrm{C} \mathrm{m}^{-2} \mathrm{~s}^{-1} \quad(0.2-$ $0.3 \times 10^{10} \mathrm{~kg} \mathrm{C} \mathrm{m}^{-2} \mathrm{~s}^{-1}$ ) for sesquiterpenes, respectively. For methanol, in summer, high emitting areas also appear in $\mathrm{Eu}-$ rope and Russia, with values of $0.3-0.5 \times 10^{10} \mathrm{~kg} \mathrm{C} \mathrm{m}^{-2} \mathrm{~s}^{-1}$ for ORCHIDEE and $0.1-0.3 \times 10^{10} \mathrm{~kg} \mathrm{C} \mathrm{m}^{-2} \mathrm{~s}^{-1}$ for MEGAN. Indeed, these regions are populated by temperate and boreal needleleaf evergreen trees, which are strong methanol emitters (Table 3 and Fig. 7, last row).

In southeastern China and southeastern United States, for methanol, acetone and, to a lesser extent, monoterpenes, ORCHIDEE emission estimates are higher than MEGAN. This is directly linked to the larger fraction of temperate needleleaf evergreen trees (TeNeEv) in ORCHIDEE in comparison to MEGAN (not shown), which are strong emitters of these compounds. The emission potentials (last row, Figs. 68 ) show the same geographical pattern that is mainly driven by the PFT distribution in these regions.

Other notable differences between the two models appear in South America for isoprene, directly in relation with the EP distribution. The pattern of isoprene emission in MEGAN has higher values in western Brazil, Bolivia and northern Argentina, while in ORCHIDEE the values are more homogeneous, with higher emissions in central Brazil. The same pattern differences are detected in the emission potential (Fig. 5, last row on the right), and we therefore infer that the EP distribution drives the isoprene emission geographical distribution. The same conclusion also holds for monoterpenes, where lower emissions along the Amazonian river follow the 

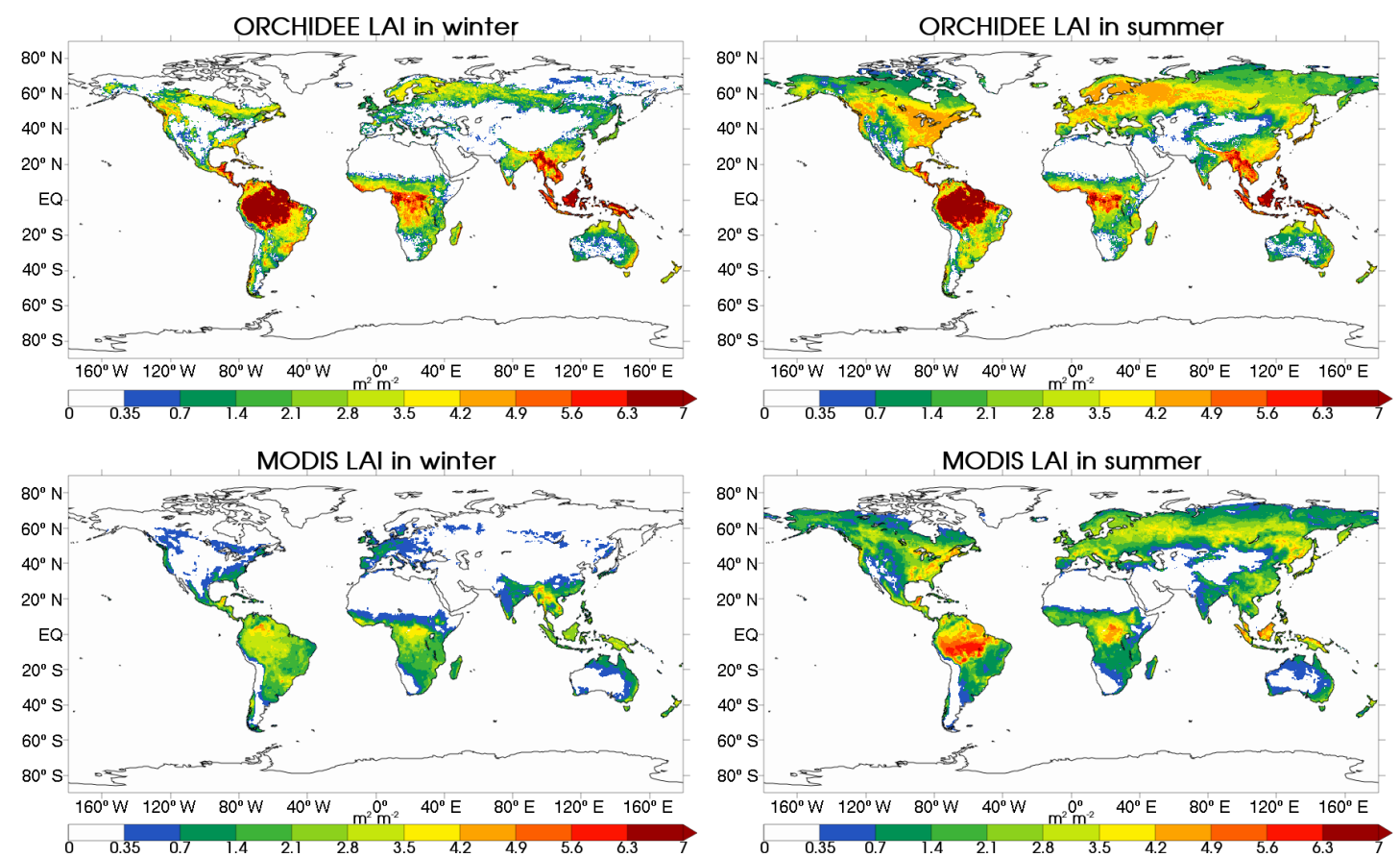

Figure 4. Leaf area index (LAI) considered for BVOC emission estimates in ORCHIDEE (LAI calculated on line) and in MEGAN (MODIS

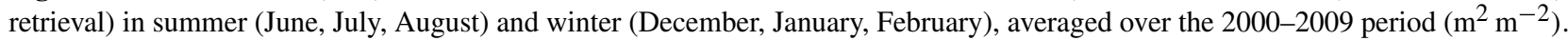

lower EPs in this area perfectly. In general, comparing the emission geographical distribution for each compound and the corresponding emission potential, we can state that, in both models, emission spatial patterns are mostly affected by the EF and PFT distributions.

\subsection{BVOC emission sensitivity to LAI}

In this section, we investigate the differences between the two models arising from LAI in detail, and we explore to what extent LAI can affect BVOC emission estimates.

Figures 4 and 10 show large differences in the geographical distribution and global average of ORCHIDEE LAI and MODIS LAI (Yuan et al., 2011). As illustrated in Fig. 10, the global monthly mean LAI calculated by ORCHIDEE is $1.5-2 \mathrm{~m}^{2} \mathrm{~m}^{-2}$ higher compared to the LAI used in MEGAN and based on MODIS data sets. In addition the LAI peaks at different times throughout the year in ORCHIDEE and MEGAN. We investigate the contribution of different areas and we observe that whilst in northern temperate regions, the MODIS LAI peaks in July and afterwards decreases quite quickly, the ORCHIDEE LAI peaks in both July and August. Furthermore, in the boreal region, the ORCHIDEE LAI peaks 1 month later (August) than the MODIS LAI (July). Therefore, the time shift observed globally is due to the greater persistence of the growing season provided by ORCHIDEE in the northern temperate area and its delay in the northern boreal region compared with what is detected by MODIS.
Furthermore, in the tropics, the MODIS LAI exhibits quite a clear seasonal cycle, especially in Amazonia, central Africa and Indonesia, which is not simulated by ORCHIDEE (Fig. 4).

The differences between these LAI estimates are significant, but our current state of knowledge does not allow us to establish which estimate is more reliable. Field and satellite data provide very useful and complementary information regarding the order of magnitude and the seasonal and the geographical variability of LAI. Nevertheless, inferring values for LAI on small or large regional scales is particularly challenging, and data available from either field or satellite measurements also have significant uncertainties. Satellites, for instance, do not measure the real LAI, but the effective LAI obtained from indirect optical methods and strongly determined by the a priori assumptions necessary for the inversion procedure. Even starting from the same input reflectance, diverse retrieval methods can lead to LAI values that are highly different (Garrigues et al., 2008; Fang et al., 2013). The effective LAI can be very dissimilar to the LAI directly measured in situ, and relative differences can reach $100 \%$ (Fang et al., 2012a, b).

The transition from effective to real LAI is only possible when additional information about the vegetation structure is available (Pinty et al., 2011), increasing the risk of inaccuracy. The sources of uncertainties are numerous (Garrigues et al., 2008). First, foliage clumping is, in general, not taken into account, leading to underestimates of LAI of up to $70 \%$ over the coniferous forest. Second, the forest understory is 

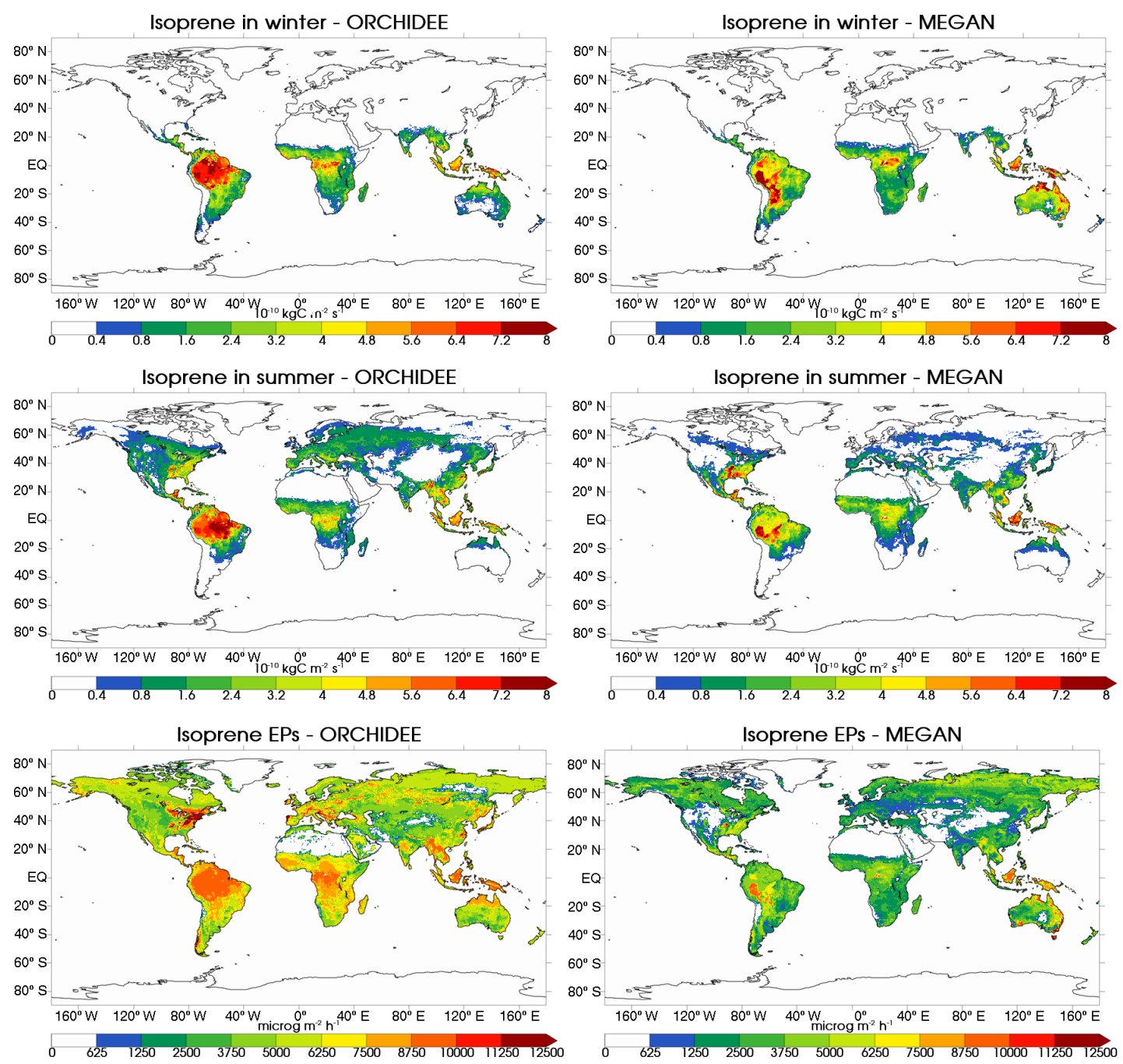

Figure 5. Emissions in winter (first row) and summer (second row) in $10^{-10} \mathrm{~kg} \mathrm{C} \mathrm{m}^{-2} \mathrm{~s}^{-1}$ and emission potentials (EPs) (third row) in $\mu \mathrm{g} \mathrm{m}^{-2} \mathrm{~h}^{-1}$ for ORCHIDEE (ORC_CRU, left column) and MEGAN (MEG_CRU, right column) for isoprene.

not systematically taken into account since the satellite LAI product is derived from a vertical integrated radiation signal. Third, in dense canopies, such as broadleaf tropical forests, the optical signal can saturate, leading to an underestimate of the effective LAI in comparison with the true value with a saturation limit of $3.0 \mathrm{~m}^{2} \mathrm{~m}^{-2}$ (Pinty et al., 2011). Fourth, the presence of ice and snow can strongly upset the retrieval, making it very difficult to estimate LAI in boreal and mountain regions.

Conversely, in a validation study using satellite-derived vegetation index time series, Maignan et al. (2011) pointed out some weaknesses in the ability of ORCHIDEE to correctly model the LAI seasonal cycle, especially in the equatorial forest (Amazonia, central Africa, Indonesia) where a poor correlation of model output with satellite data was demonstrated. In general, quite large and comparable incertitude is found when different LAI databases are compared. Krinner et al. (2005) found that the difference between OR-
CHIDEE and MODIS satellite LAI (Myneni et al., 2002) is as much as the difference between the satellite data that they used and an alternative satellite vegetation cover data set (Tucker et al., 2001). Therefore given the many existing limitations, we cannot precisely estimate to which extent ORCHIDEE LAI is reliable. It is likely that the ORCHIDEE LAI modelization has room for improvement, and a possible component to be upgraded is the allocation of the different carbon stocks, but further investigations are needed. Performing a robust evaluation of the model's ability to simulate the LAI, especially at the global scale, still remains challenging, and is beyond the scope of our study.

In this context, model inter-comparison and sensitivity tests provide an essential insight to assess the impact of different LAI estimates and their uncertainties on BVOC emissions. 

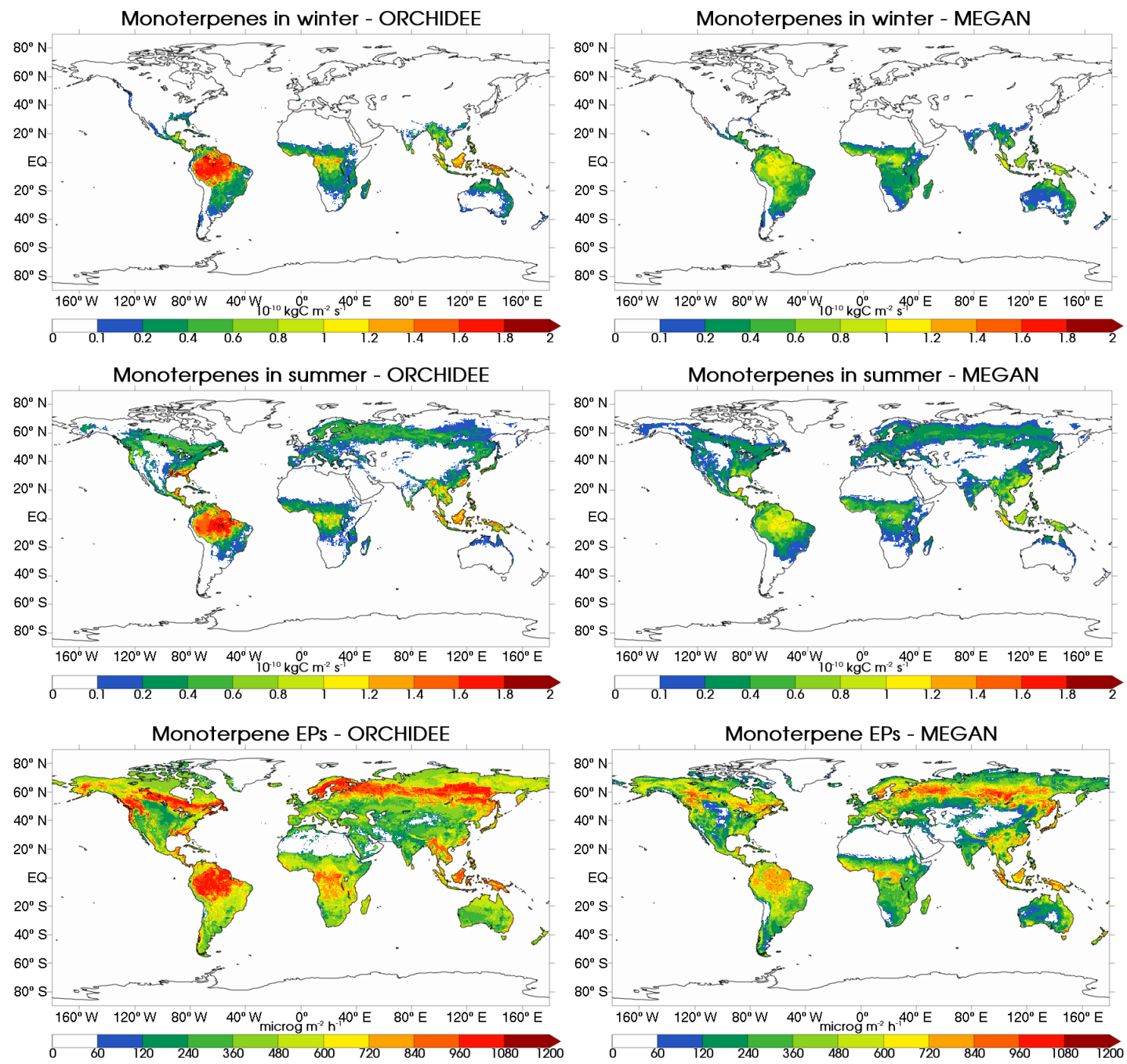

Figure 6. The same as Fig. 5, but for monoterpenes.

\subsubsection{LAI seasonal cycle impact}

LAI has an important role in driving the seasonal cycle of emissions. To show this, we perform an extra 10-year simulation following the same configuration as in the previous runs, but forcing MEGAN with the ORCHIDEE LAI (MEG_CRULAI simulation, Table 5), and we compare the results with MEG_CRU and ORC_CRU simulations.

First of all, we observe that, for the MEG_CRU simulation, the isoprene emission seasonal cycle in the tropics (particularly in the south) is more marked than for ORC_CRU simulation (Fig. 11). This behaviour is principally related to the differences in seasonal variation between the MODIS and the ORCHIDEE LAI (Fig. 4), since the ORCHIDEE LAI presents smaller variations between winter and summer in tropical regions, in particular in Amazonia, (Fig. 4, left column) in comparison with MODIS LAI (Fig. 4, right column), whereas the two models have a similar inter-seasonal variability when they are driven by

the same LAI (MEG_CRULAI and ORC_CRU). Moreover, the MEG_CRULAI simulation gives a lower peak in the northern tropics April and May emissions than MEG_CRU (Fig. 11), being more similar to ORC_CRU.

Generally, for every compound, we observe a better agreement between the MEG_CRULAI and the ORC_CRU simulations than between MEG_CRU and ORC_CRU, especially in the tropical regions.

\subsubsection{LAI range}

The global and zonal emission budgets (Table 7) in the MEG_CRULAI simulation are not significantly different than those determined in MEG_CRU, even if the ORCHIDEE LAI is significantly higher than MODIS LAI, suggesting a low sensitivity of MEGAN to LAI size. Indeed, at the regional scale, in boreal and temperate regions, the MEG_CRULAI emissions are slightly higher than those in MEG_CRU, and in the tropics they are even slightly 

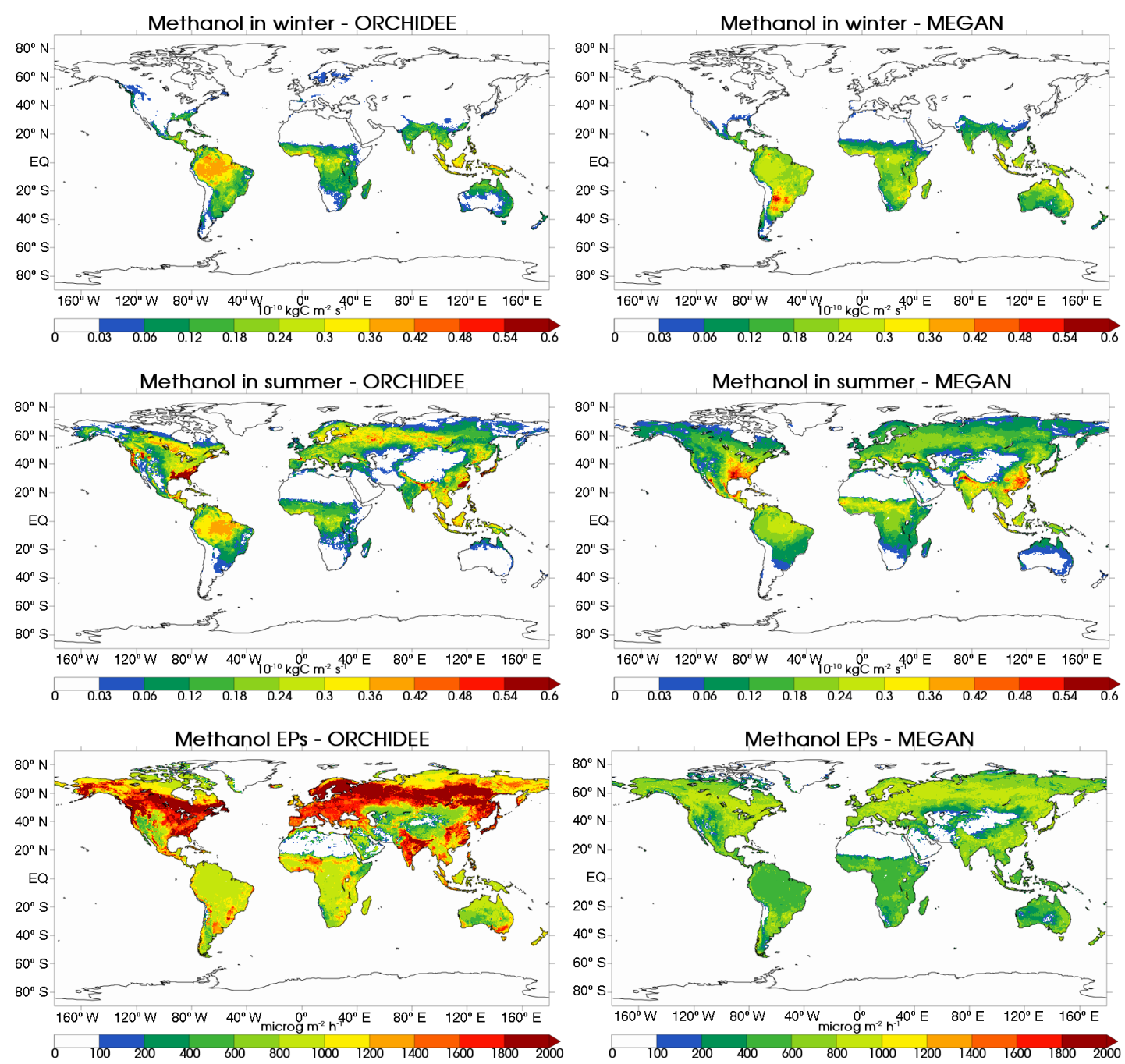

Figure 7. The same as Fig. 5, but for methanol.

lower for some compounds. As proposed by Sindelarova et al. (2014), a possible reason for the emission decrease calculated in the tropics by MEGAN is to the strengthened effect of leaf self-shading caused by an increase in LAI in locations characterized by a dense vegetation (e.g. in central Africa or Amazonia). This effect can be predominant for compounds for which biogenic emissions are strongly dependent on light, such as isoprene or methanol.

Indeed, for the other compounds the MEG_CRU and MEG_CRULAI emission budgets are very similar. We could foresee that these results are linked to the leaf self-shading effect on leaf temperature. In contrast to ORCHIDEE, where the air temperature is used, in MEGAN the leaf temperature is calculated for shaded and sunlit leaves. If the leaf selfshading effect was crucial even for light-independent compounds, we would expect a much higher leaf temperature for sunlit leaves than for shaded leaves. Calculating the difference in hourly leaf temperature between sunlit and shaded leaves in the case of dense vegetation ( $\mathrm{TrBrEv}$ and $\mathrm{TrBrDe})$, we estimate differences of about $1-1.5^{\circ} \mathrm{C}$, which would unlikely be high enough to explain such differences in emissions. Lathière et al. (2006), for instance, found that an increase in the global surface temperature by $1{ }^{\circ} \mathrm{C}$ leads to an increase of isoprene emissions of at most $11 \%$. We therefore doubt that the only mechanism behind the static BVOC emissions for light-independent compounds is leaf self-shading.

We therefore investigate in more detail whether models show the same response to a particular change in LAI. We perform two extra simulations for each model, using the ORCHIDEE LAI multiplied by a factor of 0.5 or 1.5 . The scaling factors considered are consistent with the LAI uncertainties (see the beginning of Sect. 3.4). Figure 12 shows the four simulations: MEGLAI05, ORC_LAI05 (ORCHIDEE LAI multiplied by 0.5) and MEG_LAI15 and ORC_LAI15 (ORCHIDEE LAI multiplied by 1.5), for the year 2006 (details in Table 5). Only the zonal average for the tropics and southern and northern temperate areas, for isoprene and monoter- 

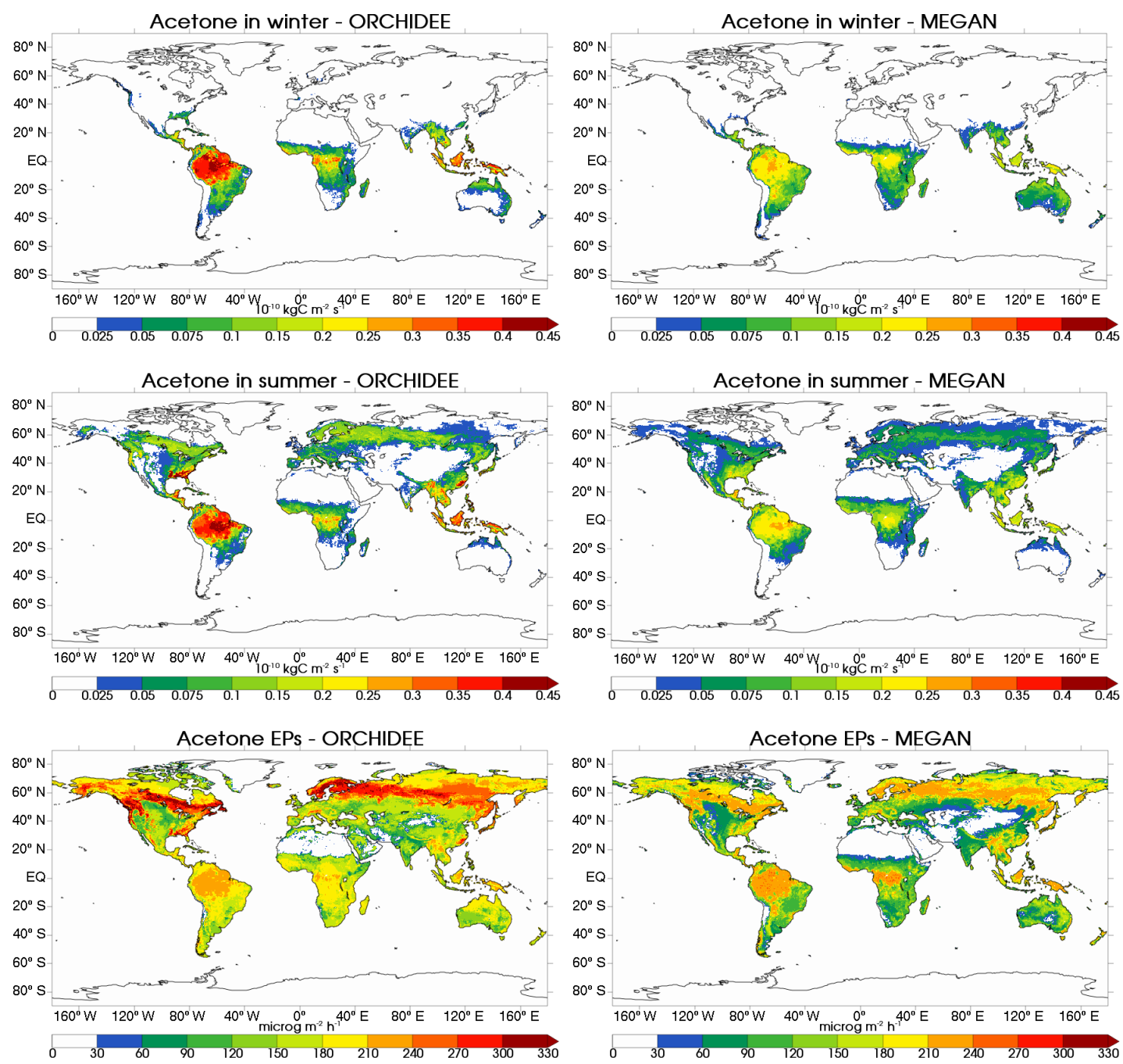

Figure 8. The same as Fig. 5, but for acetone.

penes, are displayed, but they are also representative of other regions.

Regarding isoprene, we observe that ORCHIDEE and MEGAN present a similar response to LAI variation. When the LAI is multiplied by a factor of $0.5(1.5)$, the change in emissions compared to the reference runs (MEG_CRULAI, ORC_CRU) reaches $-18 \%(+12 \%)$ for MEGAN and $-21 \%(+8 \%)$ for ORCHIDEE in the southern tropics, and reaches $-34 \%(+21 \%)$ for MEGAN and $-32 \%(+16 \%)$ for ORCHIDEE in northern temperate areas. In the tropics especially, the emissions calculated by the two models are slightly sensitive to the LAI increase. Indeed isoprene is a light-dependent compound; thus, beyond a given LAI threshold, the contribution of the highest LAI layers is very low, as there is no more or very little direct light available. We observe that MEGAN is less sensitive than ORCHIDEE to an LAI increase, which is likely due to the different parameterization of CTLD factor in the two models as described in Sect. 2.5. In more detail, as LAI increases, the growth of sunlit leaves fraction is dumped by an exponential factor as in Spitters (1986), implying a lower contribution of sunlit leaves with respect to shaded leaves for high LAI values. In MEGAN, for equal incoming radiation, the relative contribution of sunlit leaves, with respect to shaded leaves, is roughly double that in ORCHIDEE. This explains the different sensitivity of the two models.

Monoterpene emissions show a different response in terms of sensitivity to LAI. In the southern tropics, the relative difference in monoterpene emission budget between ORC_LAI05 (ORC_LAI15) and ORC_CRU is $-43 \%(+40 \%)$, and $-9 \%(+3 \%)$ between MEG_LAI05 (MEG_LAI15) and MEG_CRULAI. In northern temperate regions, the relative difference in the monoterpene emission budget between ORC_LAI05 (ORC_LAI15) and ORC_CRU is $-44 \%(+40 \%)$, and $-14 \%(+6 \%)$ between MEG_LAI05 (MEG_LAI15) and MEG_CRULAI. These simulations confirm a much smaller emission impact of LAI 

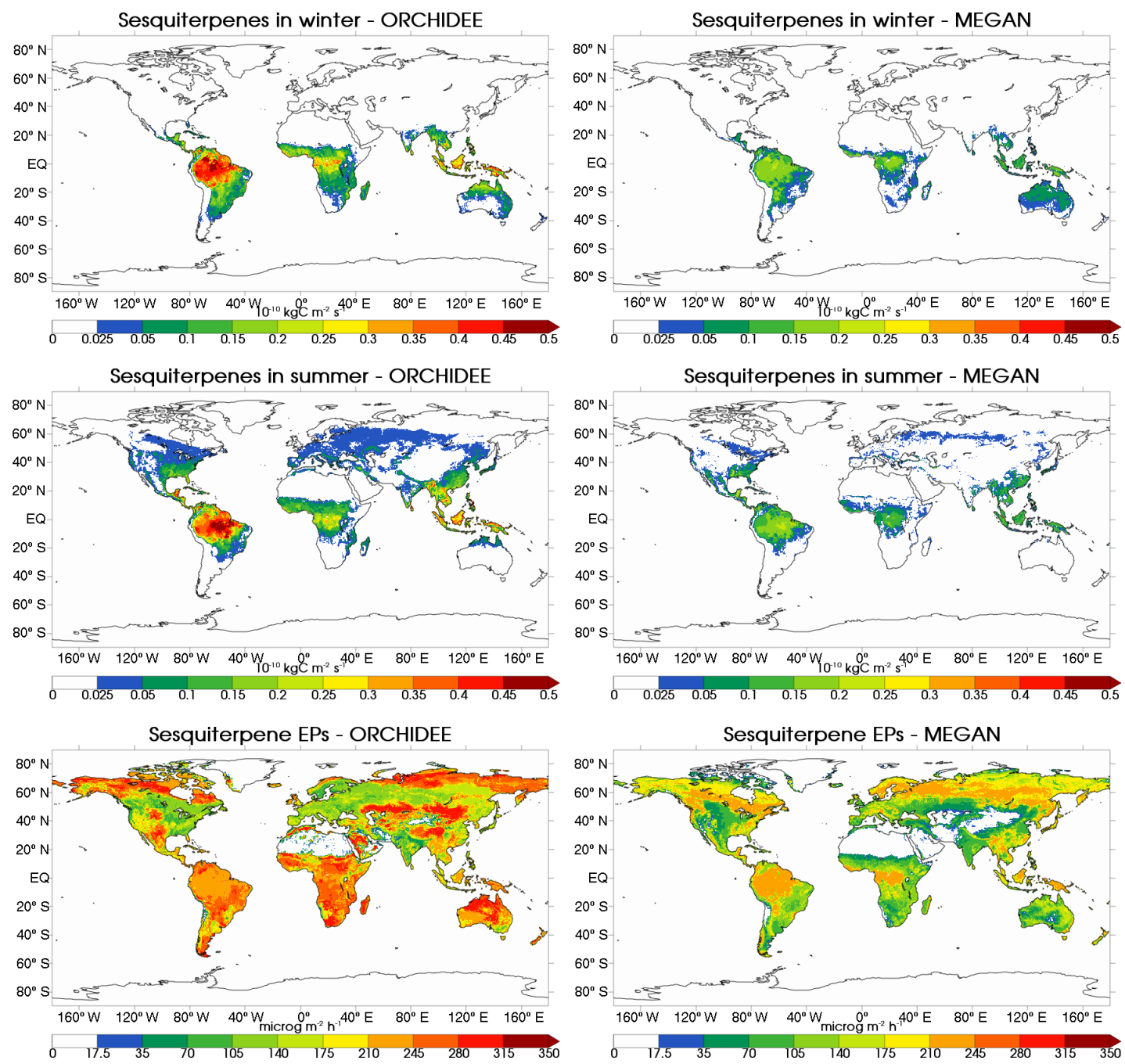

Figure 9. The same as Fig. 5, but for sesquiterpenes.

variation on emissions in MEGAN, even for compounds not fully dependent on light, such as monoterpenes $(\mathrm{LDF}=0.6)$.

Table 8 shows the total emission budget calculated for MEG_LAI05, ORC_LAI05, MEG_LAI15 and ORC_LAI15 simulations for every compound. In general in ORCHIDEE, the lower the light dependence, the higher the sensitivity to LAI, while for MEGAN, the sensitivity to LAI does not significantly change with LDF. The explanation for this difference in emission response lies in the different formulation for light-independent emissions in the two models. Such differences are detailed in point 6 of Sect. 2.5. In particular, in ORCHIDEE, the light-independent emission linearly depends on LAI, whereas in MEGAN it is determined by the $\gamma_{\text {LAI }}$ factor, and it varies almost linearly for low LAI $\left(<2 \mathrm{~m}^{2} \mathrm{~m}^{-2}\right)$ and then slowly more and more up to becoming almost constant for an LAI higher than $5 \mathrm{~m}^{2} \mathrm{~m}^{-2}$. The light-independent emission descriptions in the two models therefore respond differently to LAI variation, with differences more striking when LAI is greater than $2 \mathrm{~m}^{2} \mathrm{~m}^{-2}$. While the ORCHIDEE emissions keep increasing linearly with LAI, the MEGAN emissions do not increase as strongly anymore. In this case, the different modelling choices result in significant discrepancies in emission sensitivity between the two models.

\subsubsection{MODIS LAI}

Considering the high sensitivity of BVOC emissions to the LAI and the high differences between ORCHIDEE and MODIS LAI, we perform an additional simulation, forcing ORCHIDEE with the LAI provided by MODIS (ORC_CRUMOD) for the year 2006. Details of ORC_CRUMOD are provided in Table 5. In Fig. 13, we present the differences between the seasonal averages of ORC_CRUMOD and ORC_CRU for monoterpenes and isoprene emissions. In ORC_CRUMOD, isoprene emissions significantly decrease in the tropics, up to $3-6 \times$ $10^{-10} \mathrm{kgC} \mathrm{m}^{-2} \mathrm{~s}^{-1}$ in Brazil, in the African savanna, India and northern Australia, while they increase up to 0.75- 

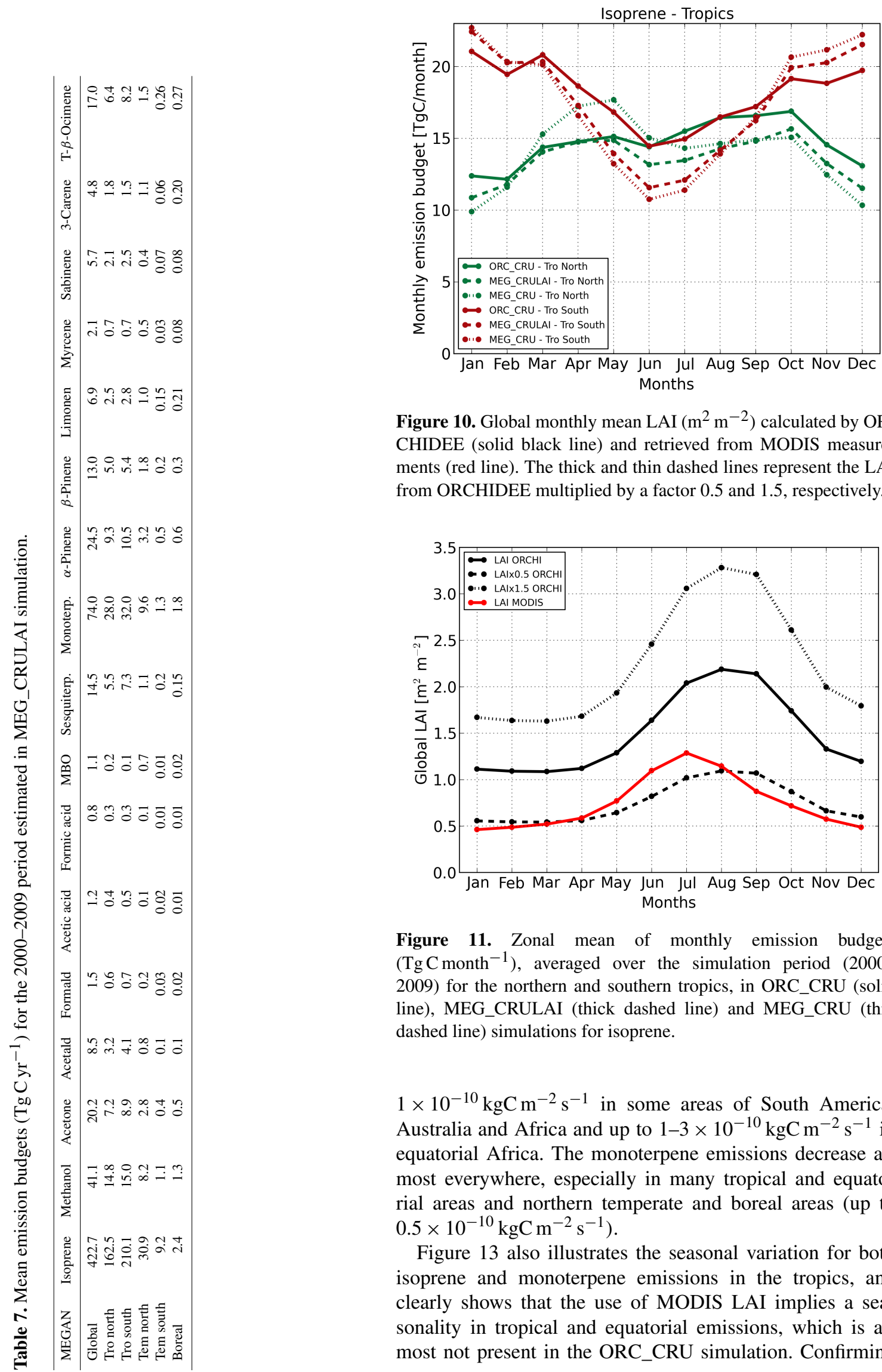

Figure 10. Global monthly mean LAI $\left(\mathrm{m}^{2} \mathrm{~m}^{-2}\right)$ calculated by ORCHIDEE (solid black line) and retrieved from MODIS measurements (red line). The thick and thin dashed lines represent the LAI from ORCHIDEE multiplied by a factor 0.5 and 1.5 , respectively.

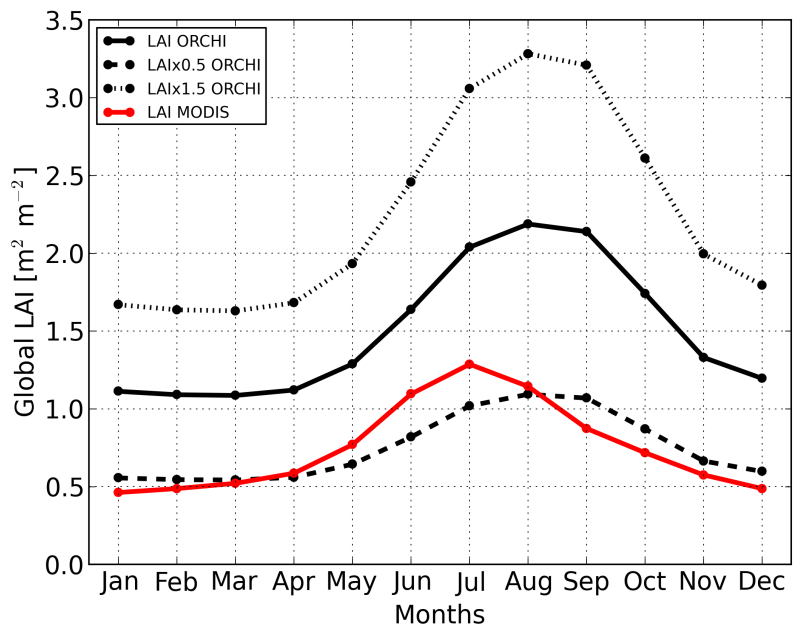

Figure 11. Zonal mean of monthly emission budgets (Tg C month ${ }^{-1}$ ), averaged over the simulation period (20002009) for the northern and southern tropics, in ORC_CRU (solid line), MEG_CRULAI (thick dashed line) and MEG_CRU (thin dashed line) simulations for isoprene.

$1 \times 10^{-10} \mathrm{kgC} \mathrm{m}^{-2} \mathrm{~s}^{-1}$ in some areas of South America, Australia and Africa and up to $1-3 \times 10^{-10} \mathrm{kgC} \mathrm{m}^{-2} \mathrm{~s}^{-1}$ in equatorial Africa. The monoterpene emissions decrease almost everywhere, especially in many tropical and equatorial areas and northern temperate and boreal areas (up to $\left.0.5 \times 10^{-10} \mathrm{kgC} \mathrm{m}^{-2} \mathrm{~s}^{-1}\right)$.

Figure 13 also illustrates the seasonal variation for both isoprene and monoterpene emissions in the tropics, and clearly shows that the use of MODIS LAI implies a seasonality in tropical and equatorial emissions, which is almost not present in the ORC_CRU simulation. Confirming 

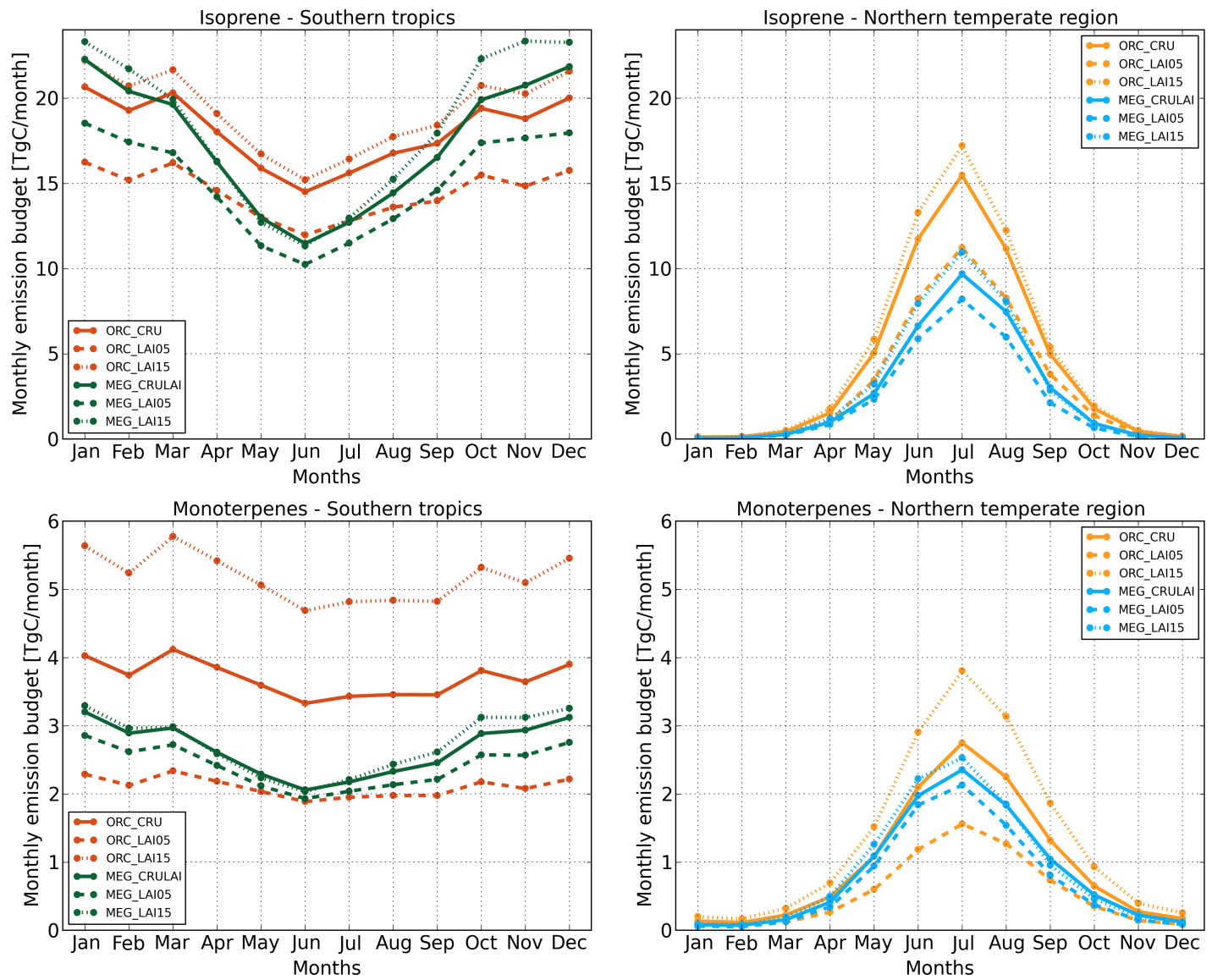

Figure 12. Zonal average of changed emissions in the different LAI sensitivity tests: ORC_CRU and MEG_CRULAI using ORCHIDEE LAI (solid line), ORC_LAI05 and MEG_LAI05 using ORCHIDEE LAI $\times 0.5$ (thick dashed line) and ORC_LAI15 and MEG_LAI15 using ORCHIDEE LAI $\times 1.5$ (thin dashed line) in the year 2006, for the southern tropical (left column) and northern temperate regions (right column) for isoprene and monoterpenes. Emissions are given in $\mathrm{Tg} \mathrm{C} \mathrm{month}^{-1}$.

the results presented in Sect. 3.4.2, monoterpene emissions show higher sensitivity to LAI variations than isoprene, with the monoterpene annual global budget for ORC_CRUMOD being $32 \%$ lower than for ORC_CRU, while for isoprene, the annual global budget is $6 \%$ lower. Considering the other species, the impact of using the MODIS LAI is stronger for species with a lower LDF. The relative difference between ORC_CRUMOD and ORC_CRU is $-4 \%$ for methanol, $-30 \%$ for acetaldehyde, formaldehyde, acetic acid and formic acid, $-36 \%$ for acetone and $-44 \%$ for MBO.

\subsection{BVOC emission sensitivity to LDF}

As described in Sect. 2.2, the LDF parameter sets the lightdependent fraction of emissions for each compound. Many experimental studies point out for several plant species that, if emissions can be totally light-independent for some BVOCs, the emissions of most of them are actually lightdependent to a degree that depends on the compound (Jacob et al., 2002, 2005; Hansen and Seufert, 2003; Dindorf et al.,
2006; Holzke et al., 2006; Harley et al., 2007; Millet et al., 2008, 2010; Hu et al., 2011; Wells et al., 2014). Since the results of these studies are highly heterogeneous, assigning a single LDF value to each compound is as difficult as assigning the EFs to each PFT (Sect. 2.2). Hence, the LDF uncertainty could be even higher than the uncertainties associated with EFs, as there have been fewer less quantitative studies on this subject published to date.

The objective of this section is to quantify, for both ORCHIDEE and MEGAN, the relative contribution of the lightdependent and light-independent part to the total emissions, and consequently to determine the impact of LDF-attributed values on emission estimates, giving clues to better understand the different behaviours of the two models.

For the fully light-dependent (isoprene: $L D F=1$ ) or largely light-dependent compounds (methanol: $\mathrm{LDF}=0.8$ ) (Figs. 5 and 7), we observe that a higher EP in ORCHIDEE than in MEGAN does not necessarily lead to higher emissions in ORCHIDEE. In the case of a LDF close to 1, even when the same EP value is used in both models, the emis- 

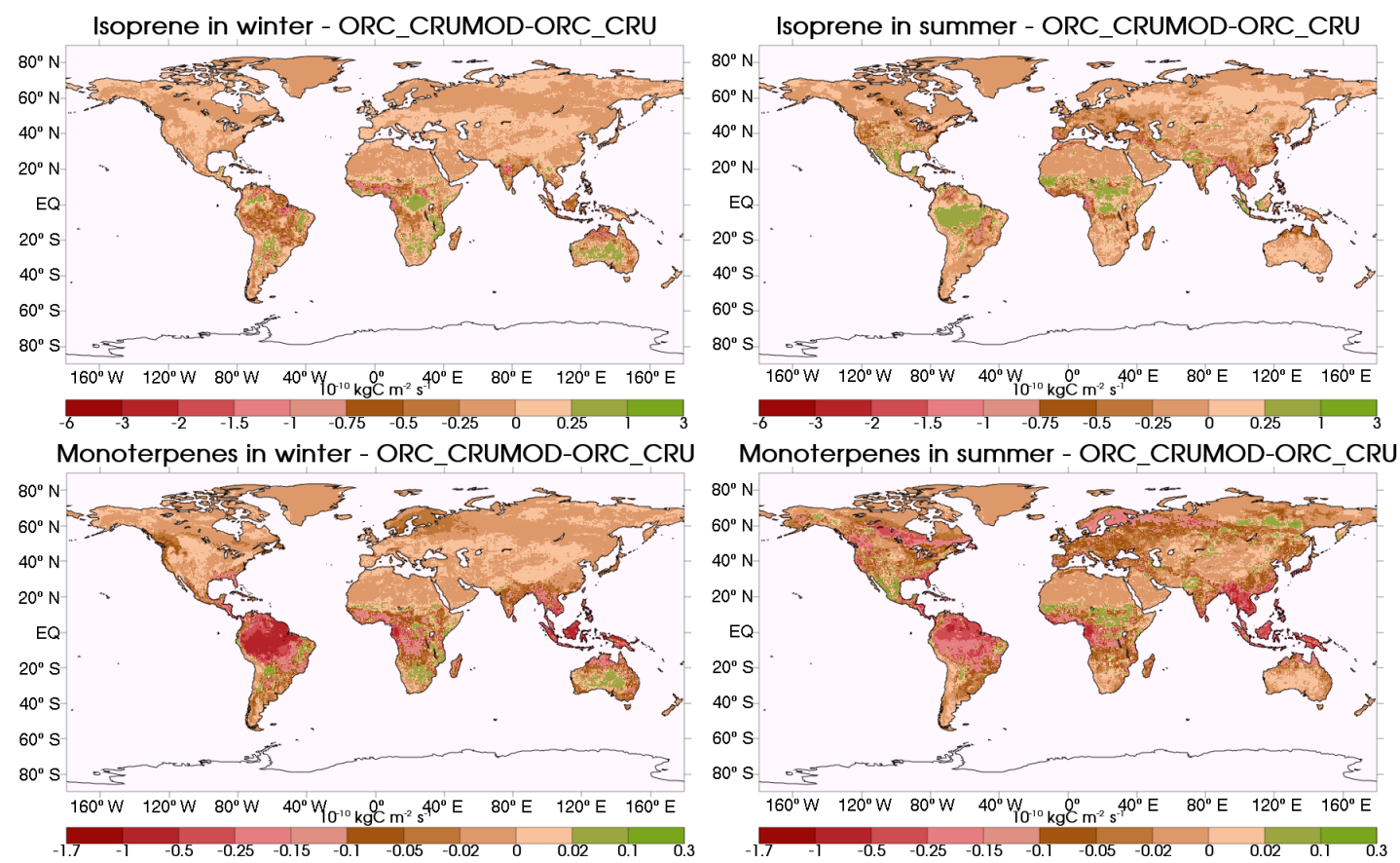

Figure 13. Differences between the ORC_CRUMOD and ORC_CRU simulation for isoprene and monoterpenes emissions in summer and winter for 2006.

sions calculated by MEGAN are higher compared to ORCHIDEE, suggesting a different emissions response to light. Indeed, this effect is less important for compounds that are less dependent on light such as monoterpenes $(\mathrm{LDF}=0.5)$ (Fig. 6) and sesquiterpenes (LDF $=0.6)($ Fig. 9), and indeed are even negligible for acetone ( $\mathrm{LDF}=0.2)$ (Fig. 8). It therefore seems that the choice of LDF parameter can be crucial in the emission estimate and in the sensitivity to EF variation.

To isolate the signal related to the LDF, we investigate the hourly variation of two "test compounds", the first defined as light-independent $(\mathrm{LDF}=0)$ and the second defined as totally light-dependent $(\mathrm{LDF}=1)$. All EFs are set to $1 \mu \mathrm{gC} \mathrm{g}-1 \mathrm{~h}^{-1}$ for each PFT. The other settings are specified as in the reference run, and are the same for the two test compounds (for further details see Table 5). We refer in the text to the first compound as orcldfo if it is calculated by ORCHIDEE and as megldfo if it is calculated by MEGAN, while we refer to the second compounds as orcldfl and megldfl, respectively.

In order to quantify the contribution of the light-dependent part in comparison to the light-independent one, we use the LDF index, which we define as the ratio between the lightdependent and the light-independent test compound, multiplied by 100 (orcldf1/orcldf0 $\cdot 100$, megldf $1 /$ megldf0 $\cdot 100$ ). Using the LDF index we can easily compare the behaviour of the two models, avoiding the complication arising from the mismatch between the two land covers. Indeed, the direct comparison of the absolute values of orcldf and megldf compounds could be affected by the differences between the PFT distributions in the two models, and the signal due to LDF change could therefore not be well isolated.

In Fig. 14 the daily profile averaged over each month of the LDF index is presented to investigate the daily and annual variations. At the global scale (left panel), we observe that the LDF index associated with MEGAN is much higher (up to $20 \%$ ) than the index associated with ORCHIDEE. At the regional scale, in the southern tropics, for example (second panel), the index reaches up to $70 \%$ and is twice as large the index calculated for ORCHIDEE. The light-dependent part of the emissions in MEGAN is therefore more important than ORCHIDEE, with important impacts on emission estimates. Firstly, we show that based on the same EF value, the MEGAN emissions are higher than in ORCHIDEE for compounds associated with high LDF, as expected from Sect. 3.3.

Secondly, the variable orcldf0 (megldf0) represents the emissions when LDF is zero, while orcldf1 (megldf1) represents the emissions when LDF is 1 ; thus, they define the interval spanned by emissions as LDF varies. Therefore, a low LDF index is associated with a greater variability of emissions for equal light-independent emissions. Consequently, ORCHIDEE results are more sensitive to LDF variation than MEGAN, as the ORCHIDEE LDF index is lower than the MEGAN index. Furthermore, the LDF index provides an evaluation of error due to a diverse choice of LDF values. The LDF index is always less than 100, meaning that the light-independent component of the emission is always bigger than the light-dependent part. Therefore, if LDF in the model is greater than it should be, emissions will be under- 

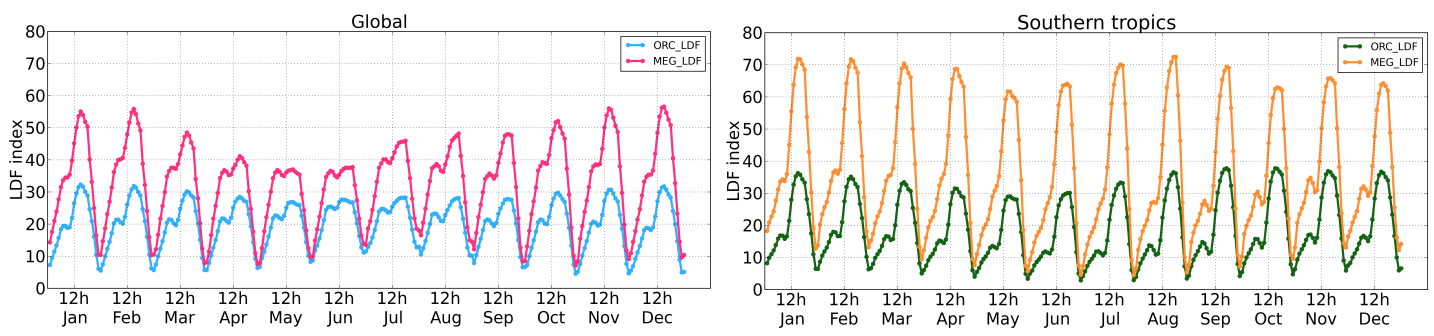

Figure 14. Global (left plot) and southern tropical (right plot) average of the LDF index for ORCHIDEE and MEGAN. The LDF index is provided as the hourly daily profile averaged over each month.

estimated, while if it is less, emissions will be overestimated. At regional scale, tropical areas, which are associated to a high LDF index, will be less sensitive to LDF variation than other regions.

\section{Conclusions}

The main objectives of this study were to (i) present the new version of the BVOC emission module embedded in the ORCHIDEE model, (ii) provide BVOC emission estimates for the 2000-2009 period for a large diversity of compounds, (iii) compare the ORCHIDEE model results to emissions calculated by MEGAN in terms of global, regional and seasonal patterns and (iv) investigate how the uncertainty linked to some key variables or parameters such as the LAI and the LDF could affect the BVOC emission estimate in the two models.

The new ORCHIDEE emission module now considers many speciated monoterpenes and bulk sesquiterpenes, which have been shown to be important regarding SOA formation, uses updated EFs and includes developments in the physical processes related to BVOC formation, such as the emission dependence on light for almost all compounds, a multi-layer calculation of diffuse and direct radiation and shaded and sunlit leaves over LAI layers.

The ORCHIDEE emission estimates are within the range of the published emission budgets. The ORCHIDEE global budgets averaged over the period investigated (2000-2009) are $465 \mathrm{Tg} \mathrm{C} \mathrm{yr}^{-1}$ for isoprene, $108 \mathrm{Tg} \mathrm{Cyr}^{-1}$ for monoterpenes, $38 \mathrm{Tg} \mathrm{C} \mathrm{yr}^{-1}$ for methanol, $25 \mathrm{Tg} \mathrm{C} \mathrm{yr}^{-1}$ for acetone and $24 \mathrm{Tg} \mathrm{Cyr}^{-1}$ for sesquiterpenes. The global emission budgets are, in general, in good agreement between the two models, with the ORCHIDEE emissions being $8 \%$ higher for isoprene, $8 \%$ lower for methanol, $17 \%$ higher for acetone, $18 \%$ higher for monoterpenes and $39 \%$ higher for sesquiterpenes compared to the MEGAN results. At the regional scale, the largest differences in terms of spatial emission distribution between ORCHIDEE and MEGAN occur in the northern temperate region for isoprene. This different behaviour is directly linked to differences in the EF and PFT distribution in this area.
More generally, considering the geographical distribution of emissions for each compound and the corresponding emission potential, we show that, in both models, EF and PFT distributions are the main drivers of the geographical emission pattern. In terms of seasonal variation, the differences between the two models in the tropics are mostly due to the different seasonal cycles of LAI between MODIS and ORCHIDEE, while the large discrepancy in northern temperate regions is attributed to differences in the EF distribution.

The LAI calculated by ORCHIDEE is $1.5-2 \mathrm{~m}^{2} \mathrm{~m}^{-2}$ higher than the LAI retrieved by MODIS. We examined how these discrepancies can impact the BVOC estimates. Sensitivity tests performed forcing both models with the ORCHIDEE LAI multiplied by a factor of 0.5 and 1.5 showed that, for isoprene, ORCHIDEE and MEGAN emissions present a similar response to these LAI variations. Conversely, for monoterpenes, ORCHIDEE is much more sensitive to LAI variations in comparison to MEGAN. These discrepancies are due to differences in the light-independent emission formulation between the two models. In ORCHIDEE, the dependence of emissions on LAI is linear, while in MEGAN it is quasi-linear for LAI up to $2 \mathrm{~m}^{2} \mathrm{~m}^{-2}$, then the increase is progressively reduced to become nearly constant for LAI greater than $5 \mathrm{~m}^{2} \mathrm{~m}^{-2}$. The sensitivity test performed forcing ORCHIDEE with MODIS LAI confirmed that in tropical areas, the principal differences between ORCHIDEE and MEGAN BVOC estimation come from the LAI, and that compounds with lower LDF show a higher sensitivity to LAI variation.

We investigated the contribution of the light-dependent and light-independent part of emissions and consequently the impact that a different choice of LDF can have on emissions. In MEGAN, the light-independent part of emissions is more important than in ORCHIDEE, reaching a factor of 2 in the southern tropics. We find that ORCHIDEE estimates are more sensitive to LDF variation than MEGAN. Moreover, we showed that overestimation (underestimation) of the LDF value leads to emission underestimation (overestimation). 


\section{Future directions}

Model inter-comparison and sensitivity tests are extremely useful to define which parameters/variables mainly affect BVOC emissions, what is the cause of this sensitivity and how estimates can be improved. Previous works have already investigated the impact of different experimental setups (climate forcing and vegetation distribution) (Arneth et al., 2011), differences in the canopy structure description (Keenan et al., 2009) and land-cover classification (Oderbolz et al., 2013) on emissions.

In the present work, we focused on the impact of LAI, LDF, EFs and PFT distribution. Our results underline that the high uncertainties in the variables/parameters involved and the different choices in modelling processes result in a high variability of BVOC emission estimates. The outcome of this analysis provides some guidelines for future developments of BVOC emission models at the global scale. In particular, the following issues should be carefully addressed.

- LAI uncertainties are still extremely high, and have a considerable impact on emissions. Improvements in LAI modelling or estimation at the global scale are essential.

- EF allocation is a big concern because of its high variability. A proper way to assign statistically robust values at a global scale has not yet been found. Significant improvement can only be achieved by increasing the observation data coverage of many regions and performing long-term measurements.

- LDF parameterization is still oversimplified, and has a significant impact on emissions. Future developments should, therefore, improve LDF parameterization accuracy, for example, by including PFT dependency. As for EFs, more reliable results can only be achieved by increasing observation coverage.

- The rather low number of PFTs in global models is a limiting factor in accurate emission estimates.

Further analysis will certainly be needed to include other important parameters/variables in the investigation, for example, leaf temperature vs. air temperature usage, leaf age classes, parameters in the Guenther formulation and the soil moisture activity factor.

Finally, it is worth mentioning that, besides model intercomparison, there is a strong need to evaluate model results against emission observations. This has already been done in other domains, for example, in atmospheric chemistry modelling (Mann et al., 2014; Tsigaridis et al., 2014). In the case of BVOCs, however, observational data are very challenging to acquire, especially on the long-term scale. Therefore, for BVOC emission modelling, a robust validation of model results against observations is still lacking. 


\section{Code and data availability}

The ORCHIDEE model code, input data, ORCHIDEE and MEGAN outputs are archived in the CEA (Commissariat à l'énergie atomique et aux énergies alternatives) highperformance computing centre TGCC and are available upon request. The source code of the MEGAN model can be downloaded from http://lar.wsu.edu/megan/guides.html (Guenther et al., 2012b).

\section{The Supplement related to this article is available online at doi:10.5194/acp-16-14169-2016-supplement.}

Acknowledgements. We thank Cathy Nangini for her very useful comments and corrections, J.-Y Peterschmitt for his help in data visualization and A. Guenther for meaningful discussions. We gratefully acknowledge support from the project ÉCLAIRE (grant agreement no. 282910), PEGASOS (grant agreement no. 265148), MACC II project (grant agreement no. 283576) and MACC-III (grant agreement no. 633080) funded under the EC Seventh Framework Programme. This work was partly funded by the DGAC under the TC2 project. This work was performed using DSM-CCRT resources under the GENCI (Grand Equipement National de Calcul Intensif) computer time allocation and the GENCI project.

Edited by: J. Rinne

Reviewed by: two anonymous referees

\section{References}

Acosta Navarro, J. C., Smolander, S., Struthers, H., Zorita, E., Ekman, A. M. L., Kaplan, J. O., Guenther, A., Arneth, A., and Riipinen, I.: Global emissions of terpenoid VOCs from terrestrial vegetation in the last millennium, J. Geophys. Res.-Atmos., 119, 6867-6885, doi:10.1002/2013JD021238, 2014.

Arneth, A., Monson, R. K., Schurgers, G., Niinemets, Ü., and Palmer, P. I.: Why are estimates of global terrestrial isoprene emissions so similar (and why is this not so for monoterpenes)?, Atmos. Chem. Phys., 8, 4605-4620, doi:10.5194/acp-8-46052008, 2008.

Arneth, A., Schurgers, G., Lathiere, J., Duhl, T., Beerling, D. J., Hewitt, C. N., Martin, M., and Guenther, A.: Global terrestrial isoprene emission models: sensitivity to variability in climate and vegetation, Atmos. Chem. Phys., 11, 8037-8052, doi:10.5194/acp-11-8037-2011, 2011.

Ashworth, K., Wild, O., and Hewitt, C. N.: Sensitivity of isoprene emissions estimated using MEGAN to the time resolution of input climate data, Atmos. Chem. Phys., 10, 1193-1201, doi:10.5194/acp-10-1193-2010, 2010.

Bai, J., Baker, B., Liang, B., Greenberg, J., and Guenther, A.: Isoprene and monoterpene emissions from an Inner Mongolia grassland, Atmos. Environ., 40, 5753-5758, doi:10.1016/j.atmosenv.2006.05.019, 2006.
Barkley, M. P., Smedt, I. De, Van Roozendael, M., Kurosu, T. P., Chance, K., Arneth, A., Hagberg, D., Guenther, A., Paulot, F., Marais, E., and Mao, J.: Top-down isoprene emissions over tropical South America inferred from SCIAMACHY and OMI formaldehyde columns, J. Geophys. Res.-Atmos., 118, 68496868, doi:10.1002/jgrd.50552, 2013.

Bauwens, M., Stavrakou, T., Müller, J.-F., De Smedt, I., and Van Roozendael, M.: Satellite-based isoprene emission estimates (2007-2012) from the GlobEmission project, in: Proceedings of the ACCENT-Plus Symposium, Atmospheric Composition Change - Policy Support and Science, Session on Short lived pollutants, climate and air quality, Urbino, Italy, 17-20 September, 2013.

Bracho-Nunez, A., Welter, S., Staudt, M., and Kesselmeier, J.: Plant- specific volatile organic compound emission rates from young and mature leaves of Mediterranean vegetation, J. Geophys. Res., 116, D16304, doi:10.1029/2010JD015521, 2011.

Chang, K. H., Yu, J. Y., Chen, T. F., and Lin, Y. P.: Estimating Taiwan biogenic VOC emission: Leaf energy balance consideration, Atmos. Environ., 43, 5092-5100, doi:10.1016/j.atmosenv.2009.06.038, 2009.

Dindorf, T., Kuhn, U., Ganzeveld, L., Schebeske, G., Ciccioli, P., Holzke, C., Köble, R., Seufert, G., and Kesselmeier, J.: Significant light and temperature dependent monoterpene emissions from European beech (Fagus sylvatica L.) and their potential impact on the European volatile organic compound budget, J. Geophys. Res., 111, 1-15, doi:10.1029/2005JD006751, 2006.

Dominguez-Taylor, P., Ruiz-Suarez, L. G., Rosas-Perez, I., Hernandez-Solis, J. M., and Steinbrecher, R.: Monoterpene and isoprene emissions from typical tree species in forests around Mexico City, Atmos. Environ., 41, 2780-2790, 2007.

Ducoudré, N. I., Laval, K., and Perrier, A.: SECHIBA, a new set of parameterizations of the hydrologic exchanges at the land-atmosphere interface within the LMD atmospheric general circulation model, J. Climate, 6, 248-273, doi:10.1175/15200442(1993)006<0248:SANSOP>2.0.CO;2, 1993.

Duhl, T. R., Helmig, D., and Guenther, A.: Sesquiterpene emissions from vegetation: a review, Biogeosciences, 5, 761-777, doi:10.5194/bg-5-761-2008, 2008.

Emmons, L. K., Walters, S., Hess, P. G., Lamarque, J.-F., Pfister, G. G., Fillmore, D., Granier, C., Guenther, A., Kinnison, D., Laepple, T., Orlando, J., Tie, X., Tyndall, G., Wiedinmyer, C., Baughcum, S. L., and Kloster, S.: Description and evaluation of the Model for Ozone and Related chemical Tracers, version 4 (MOZART-4), Geosci. Model Dev., 3, 43-67, doi:10.5194/gmd3-43-2010, 2010.

Engelhart, G. J., Asa-Awuku, A., Nenes, A., and Pandis, S. N.: CCN activity and droplet growth kinetics of fresh and aged monoterpene secondary organic aerosol, Atmos. Chem. Phys., 8, 39373949, doi:10.5194/acp-8-3937-2008, 2008.

Fang, H., Wei, S., and Liang, S.: Validation of MODIS and CYCLOPES LAI products using global field measurement data, Remote Sens. Environ., 119, 43-54, doi:10.1016/j.rse.2011.12.006, 2012a.

Fang, H., Wei, S., Jiang, C., and Scipal, K.: Theoretical uncertainty analysis of global MODIS, CYCLOPES, and GLOBCARBON LAI products using a triple collocation method, Remote Sens. Environ., 124, 610-621, doi:10.1016/j.rse.2012.06.013, 2012b. 
Fang, H., Jiang, C., Li, W., Wei, S., Baret, F., Chen, J. M., GarciaHaro, J., Liang, S., Liu, R., Myneni, R. B., Pinty, B., Xiao, Z., and Zhu, Z.: Characterization and intercomparison of global moderate resolution leaf area index (LAI) products: Analysis of climatologies and theoretical uncertainties, J. Geophys. Res.-Biogeo., 118, 529-548, doi:10.1002/jgrg.20051, 2013.

Fares, S., Gentner, D. R., Park, J.-H., Ormeno, E., Karlik, J., and Goldstein, A. H.: Biogenic emissions from Citrus species in California, Atmos. Environ., 45, 4557-4568 doi:10.1016/j.atmosenv.2011.05.066, 2011.

Fu, Y. and Liao, H.: Simulation of the interannual variations of biogenic emissions of volatile organic compounds in China: Impacts on tropospheric ozone and secondary organic aerosol, Atmos. Environ., 59, 170-185, doi:10.1016/j.atmosenv.2012.05.053, 2012.

Garrigues, S., Lacaze, R., Baret, F., Morisette, J. T., Weiss, M., Nickeson, J. E., Fernandes, R., Plummer, S., Shabanov, N. V., Myneni, R. B., Knyazikhin, Y., and Yang, W.: Validation and intercomparison of global Leaf Area Index products derived from remote sensing data, J. Geophys. Res.-Biogeo., 113, G02028, doi:10.1029/2007JG000635, 2008.

Gent, P. R., Danabasoglu, G., Donner, L. J., Holland, M. M., Hunke, E. C., Jayne, S. R., Lawrence, D. M., Neale, R. B., Rasch, P. J., Vertenstein, M., Worley, P. H., Yang, Z.-L., and Zhang, M.: The Community Climate System Model version 4, J. Climate, 24, 4973-4991, doi:10.1175/2011JCLI4083.1, 2011.

Geron, C., Guenther, A., Greenberg, J., Loescher, H. W., Clark, D., and Baker, B.: Biogenic volatile organic compound emissions from a lowland tropical wet forest in Costa Rica, Atmos. Environ., 36, 3793-3802, doi:10.1016/S1352-2310(02)00301-1, 2002.

Geron, C., Guenther, A., Greenberg, J., Karl, T., and Rasmussen, R.: Biogenic volatile organic compound emissions from desert vegetation of the southwestern US, Atmos. Environ., 40, 16451660, doi:10.1016/j.atmosenv.2005.11.011, 2006.

Ghirardo, A., Koch, K., Taipale, R., Zimmer, I., Schnitzler, J.-P., and Rinne, J.: Determination of de novo and pool emissions of terpenes from four common boreal/alpine trees by ${ }^{13} \mathrm{CO}_{2}$ labelling and PTR-MS analysis, Plant Cell Environ., 33, 781-792, doi:10.1111/j.1365-3040.2009.02104.x, 2010.

Goldstein, A. H. and Galbally, I. E.: Known and Unexplored Organic Constituents in the Earth's Atmosphere, Environ. Sci. Technol., 41, 1514-1521, 2007.

Greenberg, J. P., Guenther, A. B., Petron, G., Wiedinmyer, C., Vega, O., Gatti, L. V., Tota, J., and Fisch, G.: Biogenic VOC emissions from forested Amazonian landscapes, Glob. Change Biol., 10, 651-662, doi:10.1111/j.1365-2486.2004.00758.x, 2004.

Guenther, A., Hewitt, C. N., Erickson, D., Fall, R., Geron, C., Graedel, T., Harley, P., Klinger, L., Lerdau, M., Mckay, W. A., Pierce, T., Scholes, B., Steinbrecher, R., Tallamraju, R., Taylor, J., and Zimmerman, P.: A Global-Model of Natural Volatile Organic-Compound Emissions, J. Geophys. Res., 100, 88738892, doi:10.1029/94JD02950, 1995.

Guenther, A., Karl, T., Harley, P., Wiedinmyer, C., Palmer, P. I., and Geron, C.: Estimates of global terrestrial isoprene emissions using MEGAN (Model of Emissions of Gases and Aerosols from Nature), Atmos. Chem. Phys., 6, 3181-3210, doi:10.5194/acp-63181-2006, 2006.
Guenther, A. B., Monson, R. K., and Fall, R.: Isoprene and monoterpene emission rate variability: observations with eucalyptus and emission rate algorithm development, J. Geophys. Res., 96, 10799-10808, 1991.

Guenther, A. B., Zimmerman, P. R., Harley, P. C., Monson, R. K., and Fall, R.: Isoprene and monoterpene emission rate variability: model evaluations and sensitivity analyses, J. Geophys. Res., 98, 12609-12617, 1993.

Guenther, A. B., Jiang, X., Heald, C. L., Sakulyanontvittaya, T., Duhl, T., Emmons, L. K., and Wang, X.: The Model of Emissions of Gases and Aerosols from Nature version 2.1 (MEGAN2.1): an extended and updated framework for modeling biogenic emissions, Geosci. Model Dev., 5, 1471-1492, doi:10.5194/gmd-51471-2012, 2012a.

Guenther, A. B., Jiang, X., Duhl, T., Sakulyanontvittaya, T., Johnson, J., and Wang, X.: MEGAN version 2.10, Washington State University, available at: http://lar.wsu.edu/megan/guides. html (last access: 20 April 2015), 2012b.

Hakola, H., Tarvainen, V., Bäck, J., Ranta, H., Bonn, B., Rinne, J., and Kulmala, M.: Seasonal variation of mono- and sesquiterpene emission rates of Scots pine, Biogeosciences, 3, 93-101, doi:10.5194/bg-3-93-2006, 2006.

Hallquist, M., Wenger, J. C., Baltensperger, U., Rudich, Y., Simpson, D., Claeys, M., Dommen, J., Donahue, N. M., George, C., Goldstein, A. H., Hamilton, J. F., Herrmann, H., Hoffmann, T., Iinuma, Y., Jang, M., Jenkin, M. E., Jimenez, J. L., Kiendler-Scharr, A., Maenhaut, W., McFiggans, G., Mentel, Th. F., Monod, A., Prévôt, A. S. H., Seinfeld, J. H., Surratt, J. D., Szmigielski, R., and Wildt, J.: The formation, properties and impact of secondary organic aerosol: current and emerging issues, Atmos. Chem. Phys., 9, 5155-5236, doi:10.5194/acp-9-51552009, 2009

Hansen, U. and Seufert, G.: Temperature and light dependence of $\beta$-caryophyllene emission rates, J. Geophys. Res., 108, 1-7, doi:10.1029/2003JD003853, 2003.

Harley, P., Fridd-Stroud, V., Greenberg, J., Guenther, A., and Vasconcellos, P.: Emission of 2-methyl-3-buten-2-ol by pines: A potentially large natural source of reactive carbon to the atmosphere, J. Geophys. Res., 103, 25479, doi:10.1029/98JD00820, 1998.

Harley, P., Greenberg, J., Niinemets, Ü., and Guenther, A.: Environmental controls over methanol emission from leaves, Biogeosciences, 4, 1083-1099, doi:10.5194/bg-4-1083-2007, 2007.

Hayward, S., Tani, A., Owen, S. M., and Hewitt, C. N.: Online analysis of volatile organic compound emissions from Sitka spruce (Picea sitchensis), Tree Physiol., 24, 721-728, doi:10.1093/treephys/24.7.721, 2004.

He, C., Murray, F., and Lyons, T.: Monoterpene and isoprene emissions from 15 Eucalyptus species in Australia, Atmos. Environ., 34, 645-655, doi:10.1016/S1352-2310(99)00219-8, 2000.

Heald, C. L., Henze, D. K., Horowitz, L. W., Feddema, J., Lamarque, J. F., Guenther, A., Hess, P. G., Vitt, F., Seinfeld, J. H., Goldstein, A. H., and Fung, I.: Predicted change in global secondary organic aerosol concentrations in response to future climate, emissions, and land use change, J. Geophys. Res.-Atmos., 113, D05211, doi:10.1029/2007JD009092, 2008.

Heald, C. L., Wilkinson, M. J., Monson, R. K., Alo, C. A., Wang, G., and Guenther, A.: Response of isoprene emission to ambi- 
ent $\mathrm{CO}_{2}$ changes and implications for global budgets, Global Change Biol., 15, 1127-1140, 2009.

Helmig, D., Ortega, J., Duhl, T., Tanner, D., Guenther, A., Harley, P., Wiedinmyer, C., Milford, J., and Sakulyanontvittaya, T.: Sesquiterpene emissions from pine trees - Identifications, emission rates and flux estimates for the contiguous United States, Environ. Sci. Technol., 41, 1545-1553, doi:10.1021/es0618907, 2007.

Holzke, C., Dindorf, T., Kesselmeier, J., Kuhn, U., and Koppmann, R.: Terpene emissions from European beech (Fagus sylvatica L.): Pattern and emission behaviour over two vegetation periods, J. Atmos. Chem., 55, 81-102, doi:10.1007/s10874-006-9027-9, 2006.

Hu, L., Millet, D. B., Mohr, M. J., Wells, K. C., Griffis, T. J., and Helmig, D.: Sources and seasonality of atmospheric methanol based on tall tower measurements in the US Upper Midwest, Atmos. Chem. Phys., 11, 11145-11156, doi:10.5194/acp-1111145-2011, 2011.

Hurtt, G. C., Frolking, S., Fearon, M. G., Moore, B., Shevliakova, E., Malyshev, S., Pacala, S. W., and Houghton, R. A.: The underpinnings of land-use history: three centuries of global gridded land-use transitions, wood-harvest activity, and resulting secondary lands, Glob. Change Biol., 12, 1208-1229, doi:10.1111/j.1365-2486.2006.01150.x, 2006.

Jacob, D. J., Field, B. D., Jin, E., Bey, I., Li, Q., Logan, J., Yantosca, R. M., and Singh, H. B.: Atmospheric budget of acetone, J. Geophys. Res.-Atmos., 107, 4100, doi:10.1029/2001JD000694, 2002.

Jacob, D. J., Field, B. D., Li, Q., Blake, D. R., de Gouw, J., Warneke, C., Hansel, A., Wisthaler, A., Singh, H. B., and Guenther, A.: Global budget of methanol: Constraints from atmospheric observations, J. Geophys. Res.-Atmos., 110, 1-17, doi:10.1029/2004JD005172, 2005.

Janson, R. and De Serves, C.: Acetone and monoterpene emissions from the boreal forest in northern Europe, Atmos. Environ., 35, 4629-4637, doi:10.1016/S1352-2310(01)00160-1, 2001.

Janson, R., De Serves, C., and Romero, R.: Emission of isoprene and carbonyl compounds from a boreal forest and wetland in Sweden, Agr. Forest Meteorol., 98-99, 671-681, doi:10.1016/S0168-1923(99)00134-3, 1999.

Kalnay, E., Kanamitsu, M., Kistler, R., Collins, W., Deaven, D., Gandin, L., Iredell, M., Saha, S., White, G.,Woollen, J., Zhu, Y., Chelliah, M., Ebisuzaki, W., Higgins, W., Janowiak, J., Mo, K. C., Ropelewski, C.,Wang, J., Leetmaa, A., Reynolds, R., Jenne, R., and Joseph, D.: The ncep/ncar 40-year reanalysis project, B. Am. Meteorol. Soc., 77, 437-471, 1996.

Kanakidou, M., Seinfeld, J. H., Pandis, S. N., Barnes, I., Dentener, F. J., Facchini, M. C., Van Dingenen, R., Ervens, B., Nenes, A., Nielsen, C. J., Swietlicki, E., Putaud, J. P., Balkanski, Y., Fuzzi, S., Horth, J., Moortgat, G. K., Winterhalter, R., Myhre, C. E. L., Tsigaridis, K., Vignati, E., Stephanou, E. G., and Wilson, J.: Organic aerosol and global climate modelling: a review, Atmos. Chem. Phys., 5, 1053-1123, doi:10.5194/acp-5-1053-2005, 2005.

Karl, M., Guenther, A., Köble, R., Leip, A., and Seufert, G.: A new European plant-specific emission inventory of biogenic volatile organic compounds for use in atmospheric transport models, Biogeosciences, 6, 1059-1087, doi:10.5194/bg-6-1059-2009, 2009.
Karl, T., Potosnak, M., Guenther, A., Clark, D., Walker, J., Herrick, J. D., and Geron, C.: Exchange processes of volatile organic compounds above a tropical rain forest: Implications for modeling tropospheric chemistry above dense vegetation, J. Geophys. Res.-Atmos., 109, D18306, doi:10.1029/2004JD004738, 2004.

Karl, T., Harley, P., Guenther, A., Rasmussen, R., Baker, B., Jardine, K., and Nemitz, E.: The bi-directional exchange of oxygenated VOCs between a loblolly pine (Pinus taeda) plantation and the atmosphere, Atmos. Chem. Phys., 5, 3015-3031, doi:10.5194/acp5-3015-2005, 2005

Karl, T., Guenther, A., Yokelson, R. J., Greenberg, J., Potosnak, M., Blake, D. R., and Artaxo, P.: The tropical forest and fire emissions experiment: Emission, chemistry, and transport of biogenic volatile organic compounds in the lower atmosphere over Amazonia, J. Geophys. Res.-Atmos., 112, D18302, doi:10.1029/2007JD008539, 2007.

Keenan, T., Niinemets, Ü., Sabate, S., Gracia, C., and Peñuelas, $\mathrm{J}$.: Process based inventory of isoprenoid emissions from European forests: model comparisons, current knowledge and uncertainties, Atmos. Chem. Phys., 9, 4053-4076, doi:10.5194/acp-94053-2009, 2009.

Kesselmeier, J. and Staudt, M.: Biogenic volatile organic compounds (VOC): An overview on emission, physiology and ecology, J. Atmos. Chem., 33, 23-88, doi:10.1023/A:1006127516791, 1999.

Kesselmeier, J., Bode, K., Hofmann, U., Müller, H., Schäfer, L., Wolf, A., Ciccioli, P., Brancaleoni, E., Cecinato, A., Frattoni, M., Foster, P., Ferrari, C., Jacob, V., Fugit, J. L., Dutaur, L., Simon, V., and Torres, L.: Emission of short chained organic acids, aldehydes and monoterpenes from Quercus Ilex L. and Pinus Pinea L. in relation to physiological activities, carbon budget and emission algorithms, Atmos. Environ., 31, 119-133, doi:10.1016/S1352-2310(97)00079-4, 1997.

Kesselmeier, J., Bode, K., Gerlach, C. and Jork, E. M.: Exchange of atmospheric formic and acetic acids with trees and crop plants under controlled chamber and purified air conditions, Atmos. Environ., 32, 1765-1775, doi:10.1016/S1352-2310(97)00465-2, 1998.

Kim, S., Karl, T., Guenther, A., Tyndall, G., Orlando, J., Harley, P., Rasmussen, R., and Apel, E.: Emissions and ambient distributions of Biogenic Volatile Organic Compounds (BVOC) in a ponderosa pine ecosystem: interpretation of PTR-MS mass spectra, Atmos. Chem. Phys., 10, 1759-1771, doi:10.5194/acp-101759-2010, 2010.

Klinger, L. F., Li, Q. J., Guenther, A. B., Greenberg, J. P., Baker, B., and Bai, J. H.: Assessment of volatile organic compound emissions from ecosystems of China, J. Geophys. Res.-Atmos., 107, 4603, doi:10.1029/2001JD001076, 2002.

Krinner, G., Viovy, N., de Noblet-Ducoudré, N., Ogée, J., Polcher, J., Friedlingstein, P., Ciais, P., Sitch, S., and Prentice, I. C.: A dynamic global vegetation model for studies of the coupled atmosphere-biosphere system, Global Biogeochem. Cy., 19, 133, doi:10.1029/2003GB002199, 2005.

Kuhn, U., Rottenberger, S., Biesenthal, T., Wolf, A., Schebeske, G., Ciccioli, P., Brancaleoni, E., Frattoni, M., Tavares, T. M., and Kesselmeier, J.: Isoprene and monoterpene emissions of Amazonian tree species during the wet season: direct and indirect investigations on controlling environmental functions, J. Geophys. Res., D107, 8071, doi:10.1029/2001JD000978, 2002. 
Kuhn, U., Andreae, M. O., Ammann, C., Araújo, A. C., Brancaleoni, E., Ciccioli, P., Dindorf, T., Frattoni, M., Gatti, L. V., Ganzeveld, L., Kruijt, B., Lelieveld, J., Lloyd, J., Meixner, F. X., Nobre, A. D., Pöschl, U., Spirig, C., Stefani, P., Thielmann, A., Valentini, R., and Kesselmeier, J.: Isoprene and monoterpene fluxes from Central Amazonian rainforest inferred from towerbased and airborne measurements, and implications on the atmospheric chemistry and the local carbon budget, Atmos. Chem. Phys., 7, 2855-2879, doi:10.5194/acp-7-2855-2007, 2007.

Lamarque, J.-F., Bond, T. C., Eyring, V., Granier, C., Heil, A., Klimont, Z., Lee, D., Liousse, C., Mieville, A., Owen, B., Schultz, M. G., Shindell, D., Smith, S. J., Stehfest, E., Van Aardenne, J., Cooper, O. R., Kainuma, M., Mahowald, N., McConnell, J. R., Naik, V., Riahi, K., and van Vuuren, D. P.: Historical (1850-2000) gridded anthropogenic and biomass burning emissions of reactive gases and aerosols: methodology and application, Atmos. Chem. Phys., 10, 7017-7039, doi:10.5194/acp10-7017-2010, 2010.

Laothawornkitkul, J., Taylor, J. E., Paul, N. D., and Hewitt, C. N.: Biogenic volatile organic compounds in the Earth system: Tansley review, New Phytol., 183, 27-51, doi:10.1111/j.14698137.2009.02859.x, 2009.

Lathière, J., Hauglustaine, D. A., Friend, A. D., De NobletDucoudré, N., Viovy, N., and Folberth, G. A.: Impact of climate variability and land use changes on global biogenic volatile organic compound emissions, Atmos. Chem. Phys., 6, 2129-2146, doi:10.5194/acp-6-2129-2006, 2006.

Lathière, J., Hewitt, C. N., and Beerling, D. J.: Sensitivity of isoprene emissions from the terrestrial biosphere to 20th century changes in atmospheric $\mathrm{CO}_{2}$ concentration, climate, and land use, Global Biochem. Cy., 24, GB1004, doi:10.1029/2009GB003548, 2010.

Lawrence, D. M., Oleson, K. W., Flanner, M. G., Thornton, P. E., Swenson, S. C., Lawrence, P. J., Zeng, X., Yang, Z.-L., Levis, S., Sakaguchi, K., Bonan, G. B., and Slater, A. G.: Parameterization improvements and functional and structural advances in version 4 of the Community Land Model, J. Adv. Model. Earth Syst., 3, M03001, doi:10.1029/2011MS000045, 2011.

Lawrence, P. J. and Chase, T. N.: Representing a new MODIS consistent land surface in the Community Land Model (CLM 3.0), J. Geophys. Res.-Biogeo., 112, G01023, doi:10.1029/2006JG000168, 2007.

Leung, D. Y. C., Wong, P., Cheung, B. K. H., and Guenther, A.: Improved land cover and emission factors for modeling biogenic volatile organic compounds emissions from Hong Kong, Atmos. Environ., 44, 1456-1468, doi:10.1016/j.atmosenv.2010.01.012, 2010.

Levis S., Wiedinmyer, C., Bonan, G. B., and Guenther, A.: Simulating biogenic volatile organic compound emissions in the Community Climate System Model, J. Geophys. Res., 108, 4659, doi:10.1029/2002JD003203, 2003.

Loreto, F., Ciccioli, P., Cecinato, A., Brancaleoni, E., Frattoni, M., Fabozzi, C., and Tricoli, D.: Evidence of the photosynthetic origin of monoterpenes emitted by Quercus ilex L. leaves by ${ }^{13} \mathrm{C}$ labeling, Plant Physiol., 110, 1317-1322, 1996.

Maignan, F., Bréon, F.-M., Chevallier, F., Viovy, N., Ciais, P., Garrec, C., Trules, J., and Mancip, M.: Evaluation of a Global Vegetation Model using time series of satellite vegetation indices,
Geosci. Model Dev., 4, 1103-1114, doi:10.5194/gmd-4-11032011, 2011.

Mann, G. W., Carslaw, K. S., Reddington, C. L., Pringle, K. J., Schulz, M., Asmi, A., Spracklen, D. V., Ridley, D. A., Woodhouse, M. T., Lee, L. A., Zhang, K., Ghan, S. J., Easter, R. C., Liu, X., Stier, P., Lee, Y. H., Adams, P. J., Tost, H., Lelieveld, J., Bauer, S. E., Tsigaridis, K., van Noije, T. P. C., Strunk, A., Vignati, E., Bellouin, N., Dalvi, M., Johnson, C. E., Bergman, T., Kokkola, H., von Salzen, K., Yu, F., Luo, G., Petzold, A., Heintzenberg, J., Clarke, A., Ogren, J. A., Gras, J., Baltensperger, U., Kaminski, U., Jennings, S. G., O’Dowd, C. D., Harrison, R. M., Beddows, D. C. S., Kulmala, M., Viisanen, Y., Ulevicius, V., Mihalopoulos, N., Zdimal, V., Fiebig, M., Hansson, H.-C., Swietlicki, E., and Henzing, J. S.: Intercomparison and evaluation of global aerosol microphysical properties among AeroCom models of a range of complexity, Atmos. Chem. Phys., 14, 4679-4713, doi:10.5194/acp-14-4679-2014, 2014.

Mao, J., Paulot, F., Jacob, D. J., Cohen, R. C., Crounse, J. D., Wennberg, P. O., Keller, C. a., Hudman, R. C., Barkley, M. P., and Horowitz, L. W.: Ozone and organic nitrates over the eastern United States: Sensitivity to isoprene chemistry, J. Geophys. Res.-Atmos., 118, 11256-11268, doi:10.1002/jgrd.50817, 2013.

Matsunaga, S. N., Guenther, A. B., Greenberg, J. P., Potosnak, M., Papiez, M., Hiura, T., Kato, S., Nishida, S., Harley, P., and Kajii, Y.: Leaf level emission measurement of sesquiterpenes and oxygenated sesquiterpenes from desert shrubs and temperate forest trees using a liquid extraction technique, Geochem. J., 43, 179189, doi:10.2343/geochemj.1.0017, 2009.

Millet, D. B., Jacob, D. J., Custer, T. G., de Gouw, J. A., Goldstein, A. H., Karl, T., Singh, H. B., Sive, B. C., Talbot, R. W., Warneke, C., and Williams, J.: New constraints on terrestrial and oceanic sources of atmospheric methanol, Atmos. Chem. Phys., 8, 68876905, doi:10.5194/acp-8-6887-2008, 2008.

Millet, D. B., Guenther, A., Siegel, D. A., Nelson, N. B., Singh, H. B., de Gouw, J. A., Warneke, C., Williams, J., Eerdekens, G., Sinha, V., Karl, T., Flocke, F., Apel, E., Riemer, D. D., Palmer, P. I., and Barkley, M.: Global atmospheric budget of acetaldehyde: 3-D model analysis and constraints from in-situ and satellite observations, Atmos. Chem. Phys., 10, 3405-3425, doi:10.5194/acp-10-3405-2010, 2010.

Mitchell, T. D. and Jones, P. D.: An improved method of constructing a database of monthly climate observations and associated high-resolution grids, Int. J. Climatol., 25, 693-712, doi:10.1002/Joc.1181, 2005.

Müller, J.-F., Stavrakou, T., Wallens, S., De Smedt, I., Van Roozendael, M., Potosnak, M. J., Rinne, J., Munger, B., Goldstein, A., and Guenther, A. B.: Global isoprene emissions estimated using MEGAN, ECMWF analyses and a detailed canopy environment model, Atmos. Chem. Phys., 8, 1329-1341, doi:10.5194/acp-81329-2008, 2008.

Myneni, R. B., Hoffman, S., Knyazikhin, Y., Privette, J. L., Glassy, J., Tian, Y., Wang, Y., Song, X., Zhang, Y., Smith, G., Lotsch, A., Friedl, M., Morisette, J. T., Votava, P., Nemani, R. R., and Running, S. W.: Global products of vegetation leaf area and fraction absorbed PAR from year one of MODIS data, Remote Sens. Environ., 83, 214-231, 2002.

Niinemets, Ü.: Controls on the emission of plant volatiles through stomata: Differential sensitivity of emission rates to 
stomatal closure explained, J. Geophys. Res., 108, 1-17, doi:10.1029/2002JD002620, 2003a.

Niinemets, Ü.: Controls on the emission of plant volatiles through stomata: A sensitivity analysis, J. Geophys. Res., 108, 1-10, doi:10.1029/2002JD002626, 2003b.

Niinemets, Ü., Arneth, A., Kuhn, U., Monson, R. K., Peñuelas, J., and Staudt, M.: The emission factor of volatile isoprenoids: stress, acclimation, and developmental responses, Biogeosciences, 7, 2203-2223, doi:10.5194/bg-7-2203-2010, 2010.

Niinemets, Ü., Kuhn, U., Harley, P. C., Staudt, M., Arneth, A., Cescatti, A., Ciccioli, P., Copolovici, L., Geron, C., Guenther, A., Kesselmeier, J., Lerdau, M. T., Monson, R. K., and Peñuelas, J.: Estimations of isoprenoid emission capacity from enclosure studies: measurements, data processing, quality and standardized measurement protocols, Biogeosciences, 8, 2209-2246, doi:10.5194/bg-8-2209-2011, 2011.

Oderbolz, D. C., Aksoyoglu, S., Keller, J., Barmpadimos, I., Steinbrecher, R., Skjøth, C. A., Plaß-Dülmer, C., and Prévôt, A. S. H.: A comprehensive emission inventory of biogenic volatile organic compounds in Europe: improved seasonality and landcover, Atmos. Chem. Phys., 13, 1689-1712, doi:10.5194/acp-131689-2013, 2013.

Ortega, J., Helmig, D., Daly, R. W., Tanner, D. M., Guenther, A. B., and Herrick, J. D.: Approaches for quantifying reactive and low-volatility biogenic organic compound emissions by vegetation enclosure techniques - Part B: Applications, Chemosphere, 72, 365-380, doi:10.1016/j.chemosphere.2008.02.054, 2008.

Owen, S. M., Harley, P., Guenther, A., and Hewitt, C. N.: Light dependency of VOC emissions from selected Mediterranean plant species, Atmos. Environ., 36, 3147-3159, 2002.

Pacifico, F., Harrison, S. P., Jones, C. D., Arneth, A., Sitch, S., Weedon, G. P., Barkley, M. P., Palmer, P. I., Serça, D., Potosnak, M., Fu, T.-M., Goldstein, A., Bai, J., and Schurgers, G.: Evaluation of a photosynthesis-based biogenic isoprene emission scheme in JULES and simulation of isoprene emissions under presentday climate conditions, Atmos. Chem. Phys., 11, 4371-4389, doi:10.5194/acp-11-4371-2011, 2011.

Padhy, P. K. and Varshney, C. K.: Isoprene emission from tropical tree species, Environ. Pollut., 135, 101-109, doi:10.1016/j.envpol.2004.10.003, 2005.

Palmer, P. I., Abbot, D. S., Fu, T.-M., Jacob, D. J., Chance, K., Kurosu, T. P., Guenther, A., Wiedinmyer, C., Stanton, J. C., Pilling, M. J., Pressley, S. N., Lamb, B., and Sumner, A. L.: Quantifying the seasonal and interannual variability of North American isoprene emissions using satellite observations of the formaldehyde column, J. Geophys. Res., 111, 1-14, doi:10.1029/2005JD006689, 2006.

Peñuelas, J. and Staudt, M.: BVOCs and global change, Trends Plant Sci., 15, 133-144, doi:10.1016/j.tplants.2009.12.005, 2010.

Pfister, G. G., Emmons, L. K., Hess, P. G., Lamarque, J. F., Orlando, J. J., Walters, S., Guenther, A., Palmer, P. I., and Lawrence, P. J.: Contribution of isoprene to chemical budgets: A model tracer study with the NCAR CTM MOZART-4, J. Geophys. Res.-Atmos., 113, 1-21, doi:10.1029/2007JD008948, 2008.

Pinty, B., Andredakis, I., Clerici, M., Kaminski, T., Taberner, M., Verstraete, M. M., Gobron, N., Plummer, S., and Widlowski, J. L.: Exploiting the MODIS albedos with the Two-Stream Inversion Package (JRC-TIP): 1. Effective leaf area index, vegeta- tion, and soil properties, J. Geophys. Res. Atmos., 116, 1-20, doi:10.1029/2010JD015372, 2011.

Prentice, I. C., Cramer, W., Harrison, S. P., Leemans, R., Monserud, R. A., and Solomon, A. M.: A global biome model based on plant physiology and dominance, soil properties and climate, J. Biogeogr., 19, 117-134, 1992.

Qian, T., Dai, A., Trenberth, K. E., and Oleson, K. W.: Simulation of global land surface conditions from 1948 to 2004, Part I: Forcing data and evaluations, J. Hydrometeorol., 7, 953-975, 2006.

Riipinen, I., Yli-Juuti, T., Pierce, J. R., Petäjä, T., Worsnop, D. R., Kulmala, M., and Donahue, N. M.: The contribution of organics to atmospheric nanoparticle growth, Nat. Geosci., 5, 453-458, doi:10.1038/ngeo1499, 2012.

Rinne, H. J. I., Guenther, A. B., Greenberg, J. P., and Harley, P. C.: Isoprene and monoterpene fluxes measured above Amazonian rainforest and their dependence on light and temperature, Atmos. Environ., 36, 2421-2426, 2002.

Ruuskanen, T. M., Hakola, H., Kajos, M. K., Hellén, H., Tarvainen, V., and Rinne, J.: Volatile organic compound emissions from Siberian larch, Atmos. Environ., 41, 5807-5812, 2007.

Schade, G. W. and Goldstein, A. H.: Fluxes of oxygenated volatile organic compounds from a ponderosa pine plantation, J. Geophys. Res., 106, 3111-3123, 2001.

Schurgers, G., Arneth, A., Holzinger, R., and Goldstein, A. H.: Process-based modelling of biogenic monoterpene emissions combining production and release from storage, Atmos. Chem. Phys., 9, 3409-3423, doi:10.5194/acp-9-3409-2009, 2009.

Shao, M., Czapiewski, K. V., Heiden, A. C., Kobel, K., Komenda, M., Koppmann, R., and Wildt, J.: Volatile organic compound emissions from Scots pine: Mechanisms and description by algorithms, J. Geophys. Res., 106, 20483-20492, 2001.

Shim, C., Wang, Y., Choi, Y., Palmer, P. I., Abbot, D. S., and Chance, K.: Constraining global isoprene emissions with Global Ozone Monitoring Experiment (GOME) formaldehyde column measurements, J. Geophys. Res.-Atmos., 110, D24301, doi:10.1029/2004JD005629, 2005.

Šimpraga, M., Verbeeck, H., Bloemen, J., Vanhaecke, L., Demarcke, M., Joó, E., Pokorska, O., Amelynck, C., Schoon, N., Dewulf, J., Van Langenhove, H., Heinesch, B., Aubinet, M., and Steppe, K.: Vertical canopy gradient in photosynthesis and monoterpenoid emissions: An insight into the chemistry and physiology behind, Atmos. Environ., 80, 85-95, doi:10.1016/j.atmosenv.2013.07.047, 2013.

Simpson, D., Benedictow, A., Berge, H., Bergström, R., Emberson, L. D., Fagerli, H., Flechard, C. R., Hayman, G. D., Gauss, M., Jonson, J. E., Jenkin, M. E., Nyíri, A., Richter, C., Semeena, V. S., Tsyro, S., Tuovinen, J.-P., Valdebenito, Á., and Wind, P.: The EMEP MSC-W chemical transport model - technical description, Atmos. Chem. Phys., 12, 7825-7865, doi:10.5194/acp-127825-2012, 2012.

Sindelarova, K., Granier, C., Bouarar, I., Guenther, A., Tilmes, S., Stavrakou, T., Müller, J.-F., Kuhn, U., Stefani, P., and Knorr, W.: Global data set of biogenic VOC emissions calculated by the MEGAN model over the last 30 years, Atmos. Chem. Phys., 14, 9317-9341, doi:10.5194/acp-14-9317-2014, 2014.

Sitch, S., Smith, B., Prentice, I. C., Arneth, A., Bondeau, A., Cramer, W., Kaplan, J. O., Levis, S., Lucht, W., Sykes, M. T., Thonicke, K., and Venevsky, S.: Evaluation of ecosystem dynamics, plant geography and terrestrial carbon cycling in the LPJ dy- 
namic global vegetation model, Glob. Change Biol., 9, 161-185, 2003.

Situ, S., Wang, X., Guenther, A., Zhang, Y., Wang, X., Huang, M., Fan, Q., and Xiong, Z.: Uncertainties of isoprene emissions in the MEGAN model estimated for a coniferous and broad-leaved mixed forest in Southern China, Atmos. Environ., 98, 105-110, doi:10.1016/j.atmosenv.2014.08.023, 2014.

Smiatek, G. and Steinbrecher, R.: Temporal and spatial variation of forest VOC emissions in Germany in the decade 1994-2003, Atmos. Environ., 40, 166-177, doi:10.1016/j.atmosenv.2005.11.071, 2006.

Smolander, S., He, Q., Mogensen, D., Zhou, L., Bäck, J., Ruuskanen, T., Noe, S., Guenther, A., Aaltonen, H., Kulmala, M., and Boy, M.: Comparing three vegetation monoterpene emission models to measured gas concentrations with a model of meteorology, air chemistry and chemical transport, Biogeosciences, 11, 5425-5443, doi:10.5194/bg-11-5425-2014, 2014.

Spirig, C., Neftel, A., Ammann, C., Dommen, J., Grabmer, W., Thielmann, A., Schaub, A., Beauchamp, J., Wisthaler, A., and Hansel, A.: Eddy covariance flux measurements of biogenic VOCs during ECHO 2003 using proton transfer reaction mass spectrometry, Atmos. Chem. Phys., 5, 465-481, doi:10.5194/acp-5-465-2005, 2005.

Spitters, C. J. T.: Separating the diffuse and direct component of global radiation and its implications for modeling canopy photosynthesis Part II. Calculation of canopy photosynthesis, Agr. Forest Meteorol., 38, 231-242, doi:10.1016/0168-1923(86)90061-4, 1986.

Spitters, C. J. T., Toussaint, H. A. J. M., and Goudriaan, J.: Separating the Diffuse and Direct Component of Global Radiation and Its Implications for Modeling Canopy Photosynthesis, Part I. Components of Incoming Radiation, Agr. Forest Meteorol., 38, 217-229, doi:10.1016/0168-1923(86)90060-2, 1986.

Spracklen, D. V. and Righelato, R.: Tropical montane forests are a larger than expected global carbon store, Biogeosciences, 11, 2741-2754, doi:10.5194/bg-11-2741-2014, 2014.

Staudt, M. and Seufert, G.: Light-dependent emission of monoterpenes by holm oak (Quercus ilex 1.), Naturwissenschaften, 82, 89-92, 1995.

Staudt, M., Wolf, A., and Kesselmeier, J.: Influence of environmental factors on the emissions of gaseous formic and acetic acids from orange (Citrus sinensis L.) foliage, Biogeochemistry, 48, 199-216, doi:10.1023/A:1006289120280, 2000.

Stavrakou, T., Müller, J.-F., De Smedt, I., Van Roozendael, M., van der Werf, G. R., Giglio, L., and Guenther, A.: Global emissions of non-methane hydrocarbons deduced from SCIAMACHY formaldehyde columns through 2003-2006, Atmos. Chem. Phys., 9, 3663-3679, doi:10.5194/acp-9-3663-2009, 2009.

Stavrakou, T., Guenther, A., Razavi, A., Clarisse, L., Clerbaux, C., Coheur, P.-F., Hurtmans, D., Karagulian, F., De Mazière, M., Vigouroux, C., Amelynck, C., Schoon, N., Laffineur, Q., Heinesch, B., Aubinet, M., Rinsland, C., and Müller, J.-F.: First space-based derivation of the global atmospheric methanol emission fluxes, Atmos. Chem. Phys., 11, 4873-4898, doi:10.5194/acp-11-4873-2011, 2011.

Stavrakou, T., Müller, J.-F., Bauwens, M., De Smedt, I., Van Roozendael, M., Guenther, A., Wild, M., and Xia, X.: Isoprene emissions over Asia 1979-2012: impact of climate and land-use changes, Atmos. Chem. Phys., 14, 4587-4605, doi:10.5194/acp14-4587-2014, 2014.

Steinbrecher, R., Hauff, K., Hakola, H., and Rössler, J.: A recise parameterization for emission modeling of isoprenoids for Boreal plants, in: Biogenic VOC Emissions and Photochemistry in the Boreal Regions of Europe - Biphorep, edited by: Laurila, T. and Lindfors, V., Air Pollution Research Report No. 70, Commission of the European Communities, Luxembourg, 29-43, 1999.

Steinbrecher, R., Smiatek, G., Köble, R., Seufert, G., Theloke, J., Hauff, K., Ciccioli, P., Vautard, R., and Curci, G.: Intra- and inter-annual variability of VOC emissions from natural and seminatural vegetation in Europe and neighbouring countries, Atmos. Environ., 43, 1380-1391, doi:10.1016/j.atmosenv.2008.09.072, 2009.

Steiner, A. H. and Goldstein, A. L.: Biogenic VOCs, in: Volatile Organic Compounds in the Atmosphere, edited by: Koppmann, R., Blackwell Publishing Ltd., 82-128, 2007.

Stewart, H. E., Hewitt, C. N., Bunce, R. G. H., Steinbrecher, R., Smiatek, G., and Schoenemeyer, T.: A highly spatially and temporally resolved inventory for biogenic isoprene and monoterpene emissions: Model description and application to Great Britain, J. Geophys. Res., 108, 4644, doi:10.1029/2002JD002694, 2003.

Taipale, R., Kajos, M. K., Patokoski, J., Rantala, P., Ruuskanen, T. M., and Rinne, J.: Role of de novo biosynthesis in ecosystem scale monoterpene emissions from a boreal Scots pine forest, Biogeosciences, 8, 2247-2255, doi:10.5194/bg-8-22472011, 2011.

Taraborrelli, D., Lawrence, M. G., Crowley, J. N., Dillon, T. J., Gromov, S., Groß, C. B. M., Vereecken, L., and Lelieveld, J.: Hydroxyl radical buffered by isoprene oxidation over tropical forests, Nat. Geosci., 5, 190-193, doi:10.1038/ngeo1433, 2012.

Tarvainen, V., Hakola, H., Hellén, H., Bäck, J., Hari, P., and Kulmala, M.: Temperature and light dependence of the VOC emissions of Scots pine, Atmos. Chem. Phys., 5, 989-998, doi:10.5194/acp-5-989-2005, 2005.

Tilmes, S., Lamarque, J.-F., Emmons, L. K., Kinnison, D. E., Ma, P.-L., Liu, X., Ghan, S., Bardeen, C., Arnold, S., Deeter, M., Vitt, F., Ryerson, T., Elkins, J. W., Moore, F., Spackman, J. R., and Val Martin, M.: Description and evaluation of tropospheric chemistry and aerosols in the Community Earth System Model (CESM1.2), Geosci. Model Dev., 8, 1395-1426, doi:10.5194/gmd-8-13952015, 2015.

Topping, D., Connolly, P., and McFiggans, G.: Cloud droplet number enhanced by co-condensation of organic vapours, Nat. Geosci., 6, 443-446, 2013.

Tsigaridis, K., Daskalakis, N., Kanakidou, M., Adams, P. J., Artaxo, P., Bahadur, R., Balkanski, Y., Bauer, S. E., Bellouin, N., Benedetti, A., Bergman, T., Berntsen, T. K., Beukes, J. P., Bian, H., Carslaw, K. S., Chin, M., Curci, G., Diehl, T., Easter, R. C., Ghan, S. J., Gong, S. L., Hodzic, A., Hoyle, C. R., Iversen, T., Jathar, S., Jimenez, J. L., Kaiser, J. W., Kirkevåg, A., Koch, D., Kokkola, H., Lee, Y. H., Lin, G., Liu, X., Luo, G., Ma, X., Mann, G. W., Mihalopoulos, N., Morcrette, J.-J., Müller, J.-F., Myhre, G., Myriokefalitakis, S., Ng, N. L., O’Donnell, D., Penner, J. E., Pozzoli, L., Pringle, K. J., Russell, L. M., Schulz, M., Sciare, J., Seland, Ø., Shindell, D. T., Sillman, S., Skeie, R. B., Spracklen, D., Stavrakou, T., Steenrod, S. D., Takemura, T., Tiitta, P., Tilmes, S., Tost, H., van Noije, T., van Zyl, P. G., von 
Salzen, K., Yu, F., Wang, Z., Wang, Z., Zaveri, R. A., Zhang, H., Zhang, K., Zhang, Q., and Zhang, X.: The AeroCom evaluation and intercomparison of organic aerosol in global models, Atmos. Chem. Phys., 14, 10845-10895, doi:10.5194/acp-1410845-2014, 2014.

Tsui, J. K.-Y., Guenther, A., Yip, W.-K., and Chen, F.: A biogenic volatile organic compound emission inventory for Hong Kong, Atmos. Environ., 43, 6442-6448, doi:10.1016/j.atmosenv.2008.01.027, 2009.

Tucker, J. C., Slayback, A. D., Pinzon, E. J., Los, O. S., Myneni, B. R., and Taylor, G. M.: Higher northern latitude normalized difference vegetation index and growing season trends from 1982 to 1999 , Int. J. Biometeorol., 45, 184-190, doi:10.1007/s00484001-0109-8, 2001.

Unger, N., Harper, K., Zheng, Y., Kiang, N. Y., Aleinov, I., Arneth, A., Schurgers, G., Amelynck, C., Goldstein, A., Guenther, A., Heinesch, B., Hewitt, C. N., Karl, T., Laffineur, Q., Langford, B., A. McKinney, K., Misztal, P., Potosnak, M., Rinne, J., Pressley, S., Schoon, N., and Serça, D.: Photosynthesis-dependent isoprene emission from leaf to planet in a global carbonchemistry-climate model, Atmos. Chem. Phys., 13, 1024310269, doi:10.5194/acp-13-10243-2013, 2013.

Van Donkelaar, A., Martin, R. V., Park, R. J., Heald, C. L., Fu, T. M., Liao, H., and Guenther, A.: Model evidence for a significant source of secondary organic aerosol from isoprene, Atmos. Environ., 41, 1267-1274, doi:10.1016/j.atmosenv.2006.09.051, 2007.
Villanueva-Fierro, I., Popp, C. J., and Martin, R. S.: Biogenic emissions and ambient concentrations of hydrocarbons, carbonyl compounds and organic acids from ponderosa pine and cottonwood trees at rural and forested sites in Central New Mexico, Atmos. Environ., 38, 249-260, 2004.

Von Kuhlmann, R., Lawrence, M. G., Crutzen, P. J., and Rasch, P. J.: A model for studies of tropospheric ozone and nonmethane hydrocarbons: Model description and ozone results, J. Geophys. Res., 108, 4294, doi:10.1029/2002JD002893, 2003.

Wells, K. C., Millet, D. B., Hu, L., Cady-Pereira, K. E., Xiao, Y., Shephard, M. W., Clerbaux, C. L., Clarisse, L., Coheur, P.F., Apel, E. C., de Gouw, J., Warneke, C., Singh, H. B., Goldstein, A. H., and Sive, B. C.: Tropospheric methanol observations from space: retrieval evaluation and constraints on the seasonality of biogenic emissions, Atmos. Chem. Phys., 12, 5897-5912, doi:10.5194/acp-12-5897-2012, 2012.

Wells, K. C., Millet, D. B., Cady-Pereira, K. E., Shephard, M. W., Henze, D. K., Bousserez, N., Apel, E. C., de Gouw, J., Warneke, C., and Singh, H. B.: Quantifying global terrestrial methanol emissions using observations from the TES satellite sensor, Atmos. Chem. Phys., 14, 2555-2570, doi:10.5194/acp-14-25552014, 2014.

Yuan, H., Dai, Y., Xiao, Z., Ji, D., and Shangguan, W.: Reprocessing the MODIS Leaf Area Index products for land surface and climate modelling, Remote Sens. Environ., 115, 1171-1187, doi:10.1016/j.rse.2011.01.001, 2011. 